US Army Corps

of Engineers ${ }_{\circledast}$

Engineer Research and

Development Center

\title{
Maintaining Salt Marshes in the Face of Sea Level Rise - Review of Literature and Techniques
}

Christine M. VanZomeren, Damarys Acevedo-Mackey,

Elizabeth O. Murray, and Trudy J. Estes

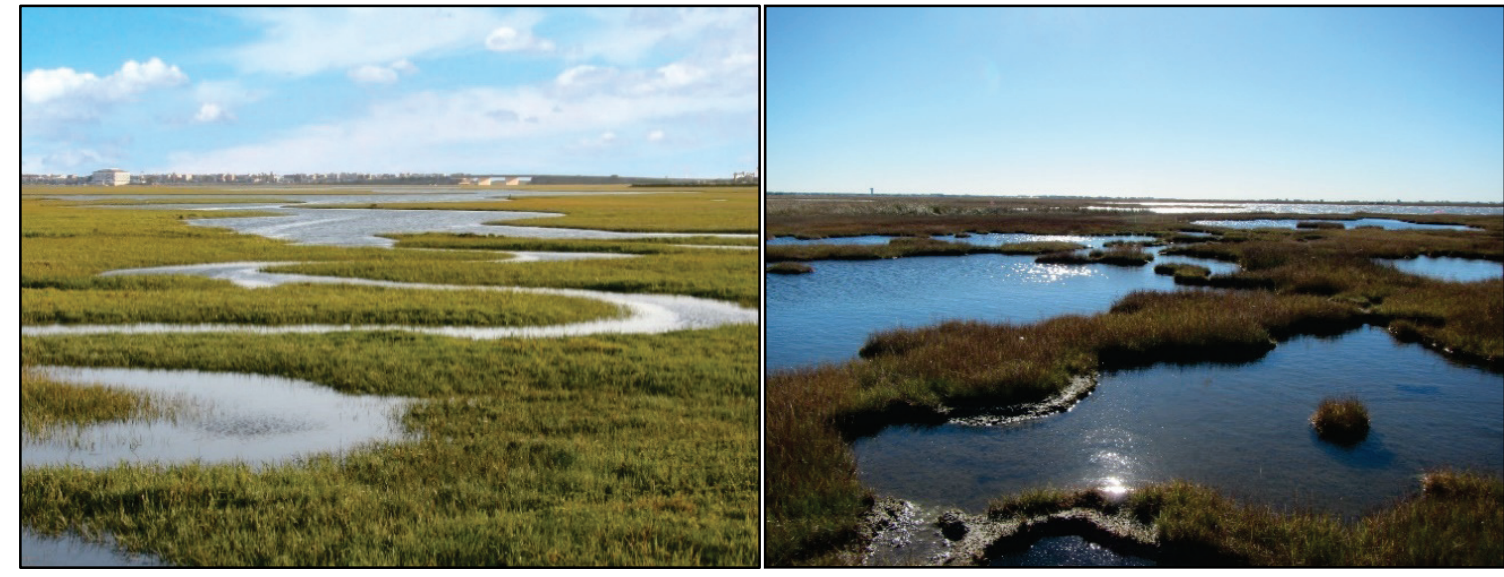

(Left) Stunted marsh vegetation at Seal Beach National Wildlife Refuge, Seal Beach CA. Photo credit: USFWS. (Right) Expanding open water areas in a marsh near Avalon, NJ. Photo credit: Christine VanZomeren. 
The U.S. Army Engineer Research and Development Center (ERDC) solves the nation's toughest engineering and environmental challenges. ERDC develops innovative solutions in civil and military engineering, geospatial sciences, water resources, and environmental sciences for the Army, the Department of Defense, civilian agencies, and our nation's public good. Find out more at www.erdc.usace.army.mil.

To search for other technical reports published by ERDC, visit the ERDC online library at http://acwc.sdp.sirsi.net/client/default. 


\section{Maintaining Salt Marshes in the Face of Sea Level Rise - Review of Literature and Techniques}

Christine M. VanZomeren, Damarys Acevedo-Mackey, Elizabeth O. Murray, and Trudy J. Estes

U.S. Army Engineer Research and Development Center Environmental Laboratory 3909 Halls Ferry Road Vicksburg, MS 39180-6199

Final report

Approved for public release; distribution is unlimited.

Prepared for U.S. Army Corps of Engineers Washington, DC 20314-1000

Under Work Unit No. 15-ER-14, "Restoring and Sustaining Ecological Function in Coastal Marshes Affected by Sea Level Rise" 


\section{Abstract}

Guidance relevant to the maintenance and restoration of coastal salt marshes in the face of sea level rise is limited and sometimes conflicting; an understanding of ecological considerations and best management practices are needed to inform restoration and management that is appropriate, timely, successful, and sustainable. A literature search was conducted to assess the severity of current and projected impacts of sea level rise on salt marshes throughout the coastal regions of the United States, to identify other stressors contributing to relative sea level rise, to assess and consolidate current practices in marsh management, and to identify knowledge gaps that are impediments to development of consistent best management practices for restoring or maintaining marshes exhibiting degradation due to relative sea level rise.

Literature identified in this search is synthesized, organized by stressor type, relevant metrics, management actions, and adaptive management. The citations are presented in such a way as to be easily utilized by managers of marshes degraded by relative sea level rise. The results of this literature search will inform data acquisition efforts to address data gaps and uncertainties necessary to support development of a holistic approach to identifying, sustaining, and restoring impacted marsh areas.

DISCLAIMER: The contents of this report are not to be used for advertising, publication, or promotional purposes. Citation of trade names does not constitute an official endorsement or approval of the use of such commercial products. All product names and trademarks cited are the property of their respective owners. The findings of this report are not to be construed as an official Department of the Army position unless so designated by other authorized documents. 


\section{Contents}

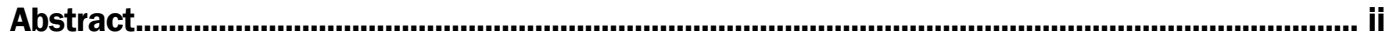

Figures and Tables......................................................................................................................................

Preface ........................................................................................................................................................ vi

Abbreviations....................................................................................................................................vii

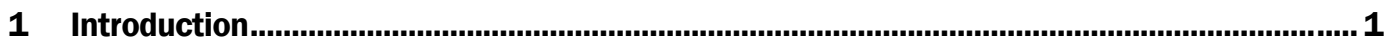

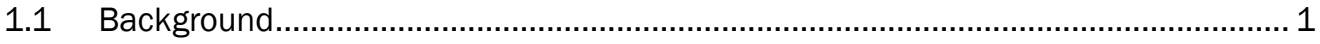

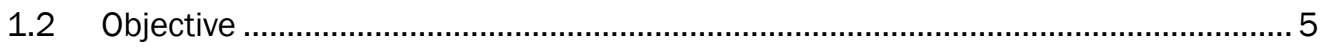

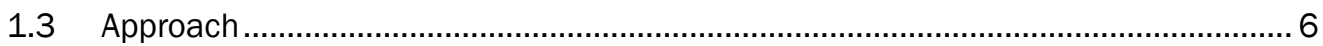

2 Relative Sea Level Rise....................................................................................................... 8

2.1 Defining relative sea level rise ...................................................................... 8

2.2 Contributing factors of relative sea level rise ..................................................... 8

2.2.1 Global sea level rise ............................................................................................... 8

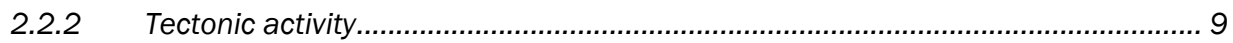

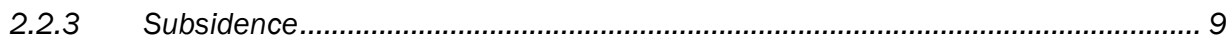

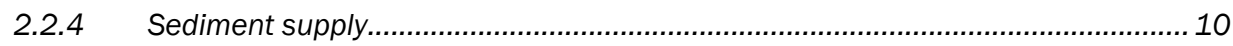

2.3 Incorporating geologic, regional, and local variations into relative sea level

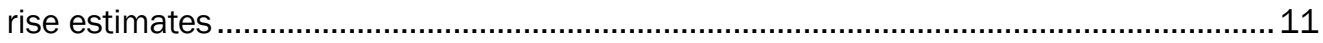

3 Impacts of Relative Sea Level Rise on Salt Marshes.............................................................12

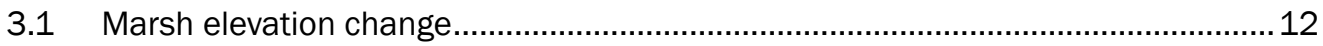

3.2 Vegetation impacts.......................................................................................... 13

3.3 Accelerated erosion ................................................................................ 14

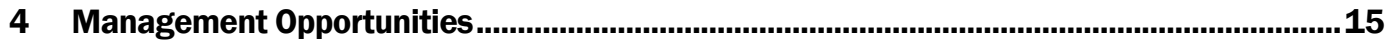

4.1 Identify the characteristics (symptoms) of marsh degradation ...............................15

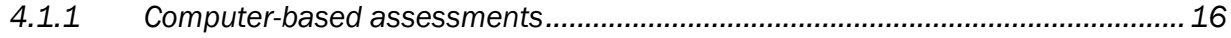

4.1.2 Ecological assessments............................................................................... 17

4.1.3 Field assessments for geomorphic and physical processes ............................... 18

4.1.4 Combining field and computer model assessments to identify the factors contributing to marsh impacts ..................................................................................... 21

4.2 Linking the symptoms of marsh degradation to appropriate restoration

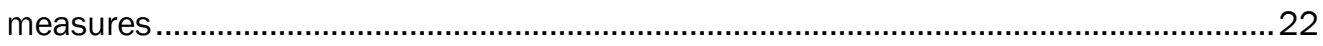

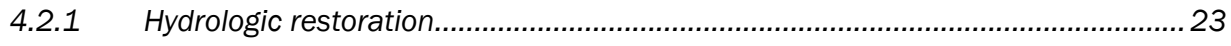

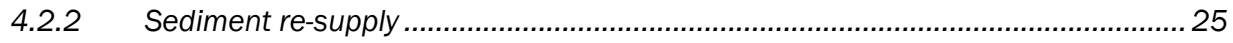

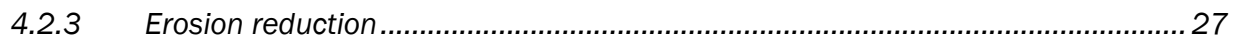

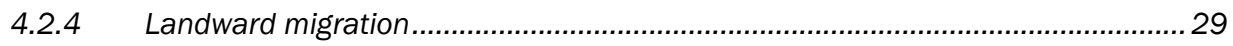

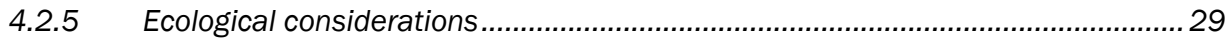

4.2.6 Engineering considerations ......................................................................... 30

4.3 Development of a comprehensive restoration strategy ........................................30

4.3.1 Establishing objectives and goals ................................................................... 31 
4.3.2 Evaluating performance success.................................................................... 32

4.3.3 Design guidance ............................................................................................. 33

4.4 Evaluate, monitor, and adaptively manage the response of salt marshes to

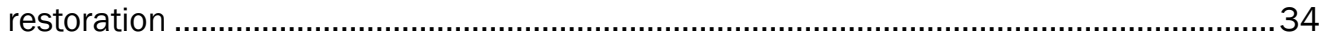

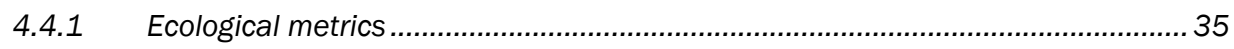

4.4.2 Geomorphic and physical processes metrics.................................................... 36

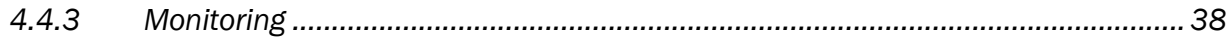

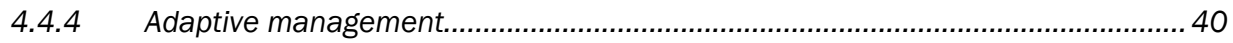

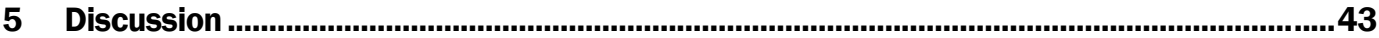

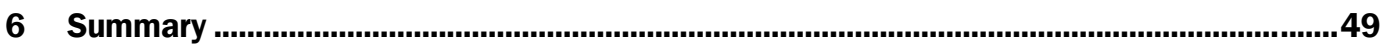

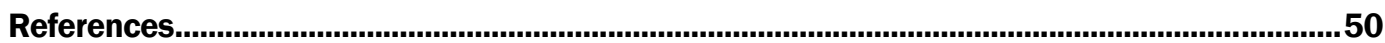

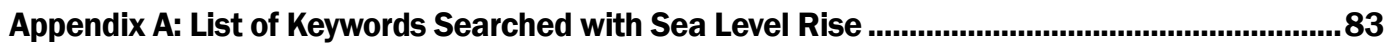

Appendix B: List of Abstracts Related to Salt Marsh Restoration ....................................................84

Report Documentation Page 


\section{Figures and Tables}

\section{Figures}

Figure 1. Linking stressors, restoration strategies, and salt marsh response to restoration strategies (modified from Allen [2000]). SOM, soil organic matter.

\section{Tables}

Table 1. Summary of predominant models used for assessing salt marsh responses to sea level rise.

Table 2. Categorization of references by restoration technique, initial assessment, metrics, monitoring, or adaptive management. Relative sea level rates and location are reported if included. Abstracts for each reference can be found in Appendix B, in addition to general information references cited in the introduction, general sea level rise, salt marsh impacts, restoration strategy, and discussion sections. 


\section{Preface}

This report is the first in a series planned for a multi-year research and development (R\&D) Work Unit No. 15-ER-14, entitled "Restoring and Sustaining Ecological Function in Coastal Marshes Affected by Sea Level Rise.” The Work Unit was funded under the Ecosystem Management and Restoration Research Program (EMRRP) sponsored by Headquarters, U.S. Army Corps of Engineers (USACE), and led by the Environmental Laboratory (EL), U.S. Army Engineer Research and Development Center (ERDC). At the time of publication of this report, Mr. Mark Farr was Chief of the Ecological Evaluation and Engineering Division of ERDC-EL; Mr. Warren Lorentz was Chief of the Environmental Processes and Engineering Division.

This report was published by ERDC under the EMRRP, which is administered under the Civil Works program Environmental Business Line. The USACE proponent for the EMRRP Program at the time of publication was Ms. Mindy Simmons, Environmental Business Line manager. The Technical Director for Civil Works, Environmental Engineering and Sciences was Dr. Al Cofrancesco, and the EMRRP Program Manager was Dr. Trudy J. Estes.

The authors deeply appreciate contributions made in developing the matrix in Table 2 by Mr. Matthew A. Ferguson, USACE, Alaska District. Technical peer review comments were provided by Dr. Tosin A. Sekoni and Ms. Susan E. Bailey (ERDC-EL); Dr. Larry Oliver, USACE, New England District; Dr. Aubree Hershorin, USACE, Jacksonville District; and Ms. Monica Chasten USACE, Philadelphia District.

The Deputy Director of ERDC-EL was Dr. Jack Davis, and the Director was Dr. Ilker R. Adiguzel.

COL Ivan P. Beckman was Commander of ERDC, and Dr. David W. Pittman was the Director. 


\section{Abbreviations}

BGE Bacterial Growth Efficiency

BACI Before-after, control-impact

CWPPRA Coastal Wetlands Planning, Protection, and Restoration Act

GIS Geographic Information Systems

EL Environmental Laboratory

EMRRP Ecosystem Management and Restoration Research Program

ERDC U.S. Army Engineer Research and Development Center

LiDAR Light Detection and Ranging

NPS National Park Service

NRC National Research Council

NY DEP New York City Department of Environmental Protection

RTK Real Time Kinematic

SET-MH Surface Elevation Table - Marker Horizon

SLAMM Sea Level Affecting Marshes Model

USACE United States Army Corps of Engineers

US FWS United States Department of Interior Fish and Wildlife Service 


\section{Introduction}

\subsection{Background}

Salt marshes are among the most productive, abundant, and fertile coastal habitats on earth, and they provide more ecosystem services to coastal populations than any other environment (Gedan et al. 2009; Zedler and Kercher 2005; Fagherazzi et al. 2013). Salt marshes provide shelter and nursery habitat for fish species, foraging and nesting habitat for endangered birds, and export organic carbon that serves as the base of a complex estuarine food web (Mitsch and Gosselink 2000). Salt marshes mitigate the flood and storm surge impacts of hurricanes and tsunamis and sequester large volumes of carbon.

Modern salt marshes established themselves approximately 2,000 years (yr) before present due to a decrease in sea level rise rate (less than 1 millimeter/yr [mm/yr]), a continuous sediment supply (Ferland 1990), and biogenic processes that maintained the habitat and increased diversity in microhabitats and species richness (Pennings and Bertness 2001). Salt marshes are found at almost all temperate latitudes in the world (Mitsch and Gosselink 2000; Palaima 2012). Within the United States, salt marshes are the dominant intertidal ecosystem along the east and Gulf coasts of the United States but are relatively rare on the West Coast except where river estuaries interrupt the rocky intertidal coastline (Palaima 2012).

Climate change and sea level rise pose an imminent threat to the survival of coastal ecosystems, including salt marshes. Although much of the foundational work on climate change started several decades ago, sea level rise acceleration, amplification of flood frequencies, and the loss of elevation capital in the marshes have made the threat imminent (Buchanan et al. 2017; Griggs et al. 2017; Thorne et al. 2016). Sea level rise presents major changes to hydrology, tidal regime, and sediment supply regime supporting ecosystem functions and processes (Allen 2000), potentially forcing an ecosystem state change (Brinson et al. 1995). Continued sea level rise over the next century is expected to exacerbate current environmental problems, including coastal erosion, subsidence, pollution, land use pressures, and deterioration of ecosystems (El-Raey et al. 1999; Webb et al. 2013). Titus et al. (1991) determined that if no 
measures are taken to hold back the sea, a 1-meter (m) rise in sea level would inundate 30,000 square kilometers $(\mathrm{sq} \mathrm{km}$ ) of wet and dry land in the United States, with each accounting for about half the loss. A key factor of coastal marsh vulnerability is whether its surface elevation can keep pace with sea level rise (Webb et al. 2013; Gedan et al. 2009) or whether stressors associated with sea level rise will disrupt normal geomorphic development and feedbacks between sea level rise, tidal regime, sedimentation, and plant vitality that typically maintain salt marsh elevations and health (Redfield 1972).

Despite restoration efforts, salt marshes along the coast of Louisiana continue to deteriorate due to the combined effects of shallow and deep subsidence, sediment depletion, and sea level rise (Jarvis 2010). Future, severe loss of New York wetlands is also projected based on relative sea level rise and sediment accretion rates (Gornitz et al. 2002). Salt marshes in New England will be dominated by cordgrass or completely lost if the rate of sea level rise continues or increases over the next century (Donnelly and Bertness 2001). While salt marshes in San Francisco Bay are presently keeping pace with sea level rise projections for 2030 through 2050 (Coastal Conservancy 2014), their fate during the next century is uncertain given the deterioration evidenced in other parts of the country, the complexity of the processes contributing to relative sea level rise, and the uncertainty associated with model projections. Continued monitoring is required to improve the confidence of model projections through improved understanding of bayland response to sea level rise and other factors, to evaluate ongoing changes, and to determine the accuracy of modeling efforts (Lowe and Bourgeois 2015).

There are multiple consequences associated with loss of coastal marsh areas, including irreversible damage to these associated ecosystems and increased risk of property damage and even loss of life. Biodiversity support, water quality improvement, flood abatement, and carbon sequestration are key functions that are impaired when wetlands are lost or degraded (Zedler and Kercher 2005). Studies show that risks associated with coastal degradation may be reduced by as much as half when coastal habitats remain fully intact, as compared to compromised habitats (Arkema et al. 2013). The risk of flood disasters is increasing for many coastal areas due to changes in climate conditions, sea level rise, land subsidence, reduced sediment supply, and geomorphic changes, leading to loss or impairment of coastal marshes. At the same time, coupled with 
ongoing coastal development and population growth, risk of property loss and loss of life is increased. More intense coastal storms overwhelm impaired coastlines (Temmerman et al. 2013; Coastal Conservancy 2014; Bridges et al. 2015) causing inundation, flood and storm damage, wetland loss and change, erosion, and saltwater intrusion leading to significant economic losses (Karamouz et al. 2013). In developed areas such as New York City or San Francisco Bay, rapid increase in sea level may have significant impacts to the economy, ecology, and culture (Collins and Ball 2015; Palaima 2012). Human development may also limit the options available for managing the impacts of sea level rise while at the same time, storms are increasing in intensity, challenging conventional engineering solutions. Maintaining and restoring marsh ecosystems may offer a more sustainable, cost-effective and ecologically sound strategy for flood protection in suitable locations. These grey/green solutions are being considered in many areas.

In addition to coastal protection, salt marshes provide critical habitat to many endangered species, both on the East and West Coasts of the United States. A study quantifying the frequency of nest-flooding events at two salt marshes showed that tide height and flooding frequency affect the vulnerabity of Saltmarsh Sparrow and light-footed Rideway's Rail (Rallus obsoletus) nests. Saltmarsh Sparrow nests are extremely vulnerable to sea level rise in East Coast salt marshes (Bayard and Elphick 2011). Likewise, nesting habitat for light-footed Ridgway's Rail (Rallus obsoletus) on the the West Coast is subject to flooding. Seal Beach National Wildlife Refuge in California provides nesting habitat for the Ridgeway Rail, whose nests are anchored to marsh grasses and float up and down with changing tidal elevation. Due to impacts of relative sea level rise (subsidence coupled with increased water levels), nests currently can simply float away at high tide. Specialized floating nesting platforms have been installed to compensate and ensure continued nest success. Without these measures, this endangered specie may become extirpated from a refuge designated specifically to maintain its population (Coastal Conservancy 2014). These are not isolated cases. Rounds et al. (2004) also conclude that rising sea levels in the mid-Atlantic region pose a long-term threat to marshes and their avian inhabitants, affecting breeding, staging, and wintering areas of many species. This has important implications with respect to site-based legal protections and international treaties, such as the United Nations Convention on Biological Diversity but rarely addresses shifts in the ability of a site to provide for critical life stage requirements, which may be 
profoundly impacted by sea level rise and climate change (Boere and Tayler 2004; Galbraith et al. 2002). Site protections that had previously been effective in supporting species may cease to effectively protect them as both sites change in response to sea level rise, and the species' change in fecundity and ranges change due to changing temperatures (Boere and Tayler 2004). In the Chesapeake Bay region, 10 of 13 colonial-nesting seabird species have declined, many significantly, since 1993 due in large part to habitat change and loss resulting from sea level rise and other factors (Brinker et al. 2007). Conservation and management of protected habitats will be necessary in the coming decades to protect endangered species and minimize additional listings.

Faced with the ecological concerns discussed above, land managers have been working to develop appropriate restoration techniques based on sound ecological and geomorphic processes that can improve ecological function of marshes impacted by sea level rise. For example, a tidal marsh in Connecticut restored to tidal flooding $20 \mathrm{yr}$ ago was monitored for bird use. The results indicate that the site supports wetland bird species at levels comparable to reference marshes, with increases in species richness and frequency of occurrence over reference sites. This is consistent with previous studies on vegetation, macroinvertebrates, and fish use. Together the monitoring efforts demonstrate that the reintroduction of tidal flooding can effectively restore important ecological functions (Brawley et al. 1998).

Some ecological concepts essential to effective management and restoration, such as ecosystem structure and function, are well understood. Carrying capacity, resilience, and the value of ecosystem goods and services provided, however, are still poorly quantified for marine and estuarine environments (Elliot et al. 2007) yet are necessary for holistic and integrated ecosystem-based management of these environments for species and societal benefits (Elliot et al. 2007; Gedan et al. 2016). To deal successfully with these unknowns and other site-specific knowledge gaps, Zedler and Kercher (2005) recommend "adaptive restoration" approaches, utilizing phased "modules" of restoration that test alternative restoration techniques. This phased approach allows for knowledge gained during restoration to be applied in subsequent phases of construction, restoration of the actual site conditions in question, and maximizes success. Adaptive restoration concepts tested at the Model Marsh project in the Tijuana Estuary, CA (Borde et al. 2004), provide a template relevant to other marsh restoration projects. 
Available guidance for the maintenance and restoration of coastal salt marshes affected by sea level rise is limited and sometimes conflicting and lacks a clear link to site-specific mechanisms of marsh degradation. As a result of these limitations, management and restoration methods may or may not be successful and have the potential to hinder rather than facilitate marsh recovery.

Best management practices (BMPs) are needed to inform identification of stress in coastal salt marshes, determine site-specific degradation mechanisms, and align restoration methods with site-specific processes and conditions. Specific objectives of the work unit include the following:

- Assess the current and anticipated impacts of sea level rise on existing tidal salt marshes

- Consolidate and evaluate the success of current marsh management practices through available case studies and literature

- Identify and/or develop consistent and robust metrics for identifying stress and associated mechanisms in coastal salt marshes to facilitate early and appropriate intervention, before the systems are compromised beyond recovery

- Investigate the suite of restoration techniques available to maintain marshes struggling with sea level rise

- Formulate ecological considerations that impact choices of management practices and address implications of different choices to fit management goals

- Recommend a suite of BMPs associated with various management strategies for a range of restoration goals.

\subsection{Objective}

The following report reviews topics related to the current knowledge of identifying degraded marshes and potential restoration techniques available for marsh impacted by sea level rise. Specific topics addressed under this effort were the following:

- Historical and projected rates of sea level rise, contributing factors and geographic differences

- Existing and historical restoration practices and effectiveness

- Availability and consistency of formal guidance specific to sea level rise adaptation strategies 
- Tools available to support the development of a consistent, adaptable, and scientifically defensible approach for the restoration of salt marshes affected by sea level rise, including the following:

- Monitoring and assessment procedures intrinsic to holistic assessment of marsh health and identification of stressors

- Models and design tools available to facilitate achievement of specific restoration objectives

- Review of restoration methodologies in use, including sediment supplementation/material placement methods, "living shoreline", erosion control measures, excavation of channels to maximize tidal range, and others

- Metrics for success - engineering and ecological considerations

- The potential role of adaptive management.

\subsection{Approach}

This special report consolidates and synthesizes published information on the state of the practice and science relevant to maintaining salt marsh habitat in the face of sea level rise. It also includes related factors such as sediment budget and hydrologic alterations. The report does not include the vast amount of information on salt marsh restoration in areas that were once salt marsh but have been isolated from tidal flows or converted to other uses. A literature search was conducted to assess the severity of the current and projected impacts of sea level rise on salt marshes throughout the coastal regions of the United States to determine what practices have been employed for restoration and what formal guidance is available for supporting impacted salt marshes in a scientifically defensible manner.

This report seeks to review methods used in existing marshes that are showing signs of degradation due to sea level rise. Factors affecting relative sea level rise and the impact on salt marshes are described. Ecological, geomorphic, and physical processes to assess and document marsh loss and degradation are identified. Innovative restoration techniques for salt marshes affected by sea level rise are described, and test cases are documented where possible. Ecological and physical metrics for assessing restoration actions are identified along with approaches for monitoring and adaptive management.

The results of this literature search will inform data acquisition efforts attempting to address data gaps and uncertainties necessary to support 
development of a holistic approach to identifying, sustaining, and restoring impacted marsh areas. Ongoing studies are mentioned in the discussion, but only published and accessible reports are included in this synthesis. Information compiled in this report will eventually inform a national framework for ecological considerations in designing restoration or maintenance plans for salt marshes affected by sea level rise. This framework will synthesize information from the literature, highlighting well-documented and ongoing restoration projects, and will offer a national view of restoration methods available and prescriptions for use over a range of conditions. 


\section{Relative Sea Level Rise}

The distinction between sea level rise, and relative sea level rise, is an important one, reflecting the aggregate effect of global, regional, and local variations in the factors contributing to sea level rise and changes in land surface elevation in coastal areas. The factors contributing to relative sea level rise are described and discussed.

\subsection{Defining relative sea level rise}

Relative sea level rise is defined as the change in sea level compared to the marsh plain elevation, due to global sea level rise and dynamic land change processes, within a particular geographic area (Garster et al. 2015; Nicholls and Cazanave 2010). Geologic, regional, and local conditions define the comparative contribution of each factor - which includes global sea level rise, tectonic activity, subsidence, and changes in sediment supply - to the rate of local relative sea level rise. Land subsidence resulting from oil and water extraction, for example, coupled with sea level rise may result in larger differential changes than global sea level rise alone. As a consequence, relative sea level rise changes the local tidal datum elevation that defines marsh inundation levels. This often leads to greater frequency and duration of salt marsh inundation. Contributing factors are fully discussed below.

\subsection{Contributing factors of relative sea level rise}

\subsubsection{Global sea level rise}

Global or eustatic sea level rise refers to an increase in the mass and volume of the ocean (Ericson et al. 2006; Nicholls 2003). The increase in ocean mass is due to the melting of continental glaciers and ice sheets whereas volume is also affected by steric effects, such as thermal expansion of ocean water as it warms and changes in salinity (Engelhart et al. 2009; Ericson et al. 2006; Mote et al. 2008; Cazenave and Nerem 2004). Average global sea level rise during the last century was $1.7 \mathrm{~mm} \mathrm{yr}^{-1}$ with an increase in the last several decades to $3.2 \mathrm{~mm} \mathrm{yr}^{-1}$ (Meyssignac and Cazenave 2012).

Global sea level rise has been considered in the U.S. Army Corps of Engineers (USACE) Civil Works programs planning for over $20 \mathrm{yr}$ (USACE 2009, 2011, 2013, 2014). The USACE utilizes a value of $1.5 \mathrm{~m}$ for global sea 
level rise by the year 2100 , with $2.0 \mathrm{~m}$ considered a credible upper bound (Hall et al. 2016; USACE 2011, 2014). Global sea level rise estimates beyond 2100 result in underestimated values due to limitations associated with ice-sheet models; however, these estimates show that future sea level rise projections (2.5-9.6 m) are substantial (Hall et al. 2016; Meehl et al. 2012) and that the sea level will continue to rise even with aggressive mitigation (Church et al. 2013; Meehl et al. 2012).

Global sea level rise projections are estimated with climate models, semiempirical approaches, or physical-based processes models (Church et al. 2013; Little et al. 2015; Rahmstorf 2007; Hall et al. 2016). Long-range projections - beyond the year 2100 - are subject to significant uncertainty due to limitations associated with understanding rates of icesheet melting.

\subsubsection{Tectonic activity}

In some locations, geologic activity contributes to changes in relative sea level rise. Plate tectonics or isostatic rebound in formerly glaciated areas are two geologic processes that can cause vertical land movement and affect the magnitude of relative sea level rise (Barber 2014; Zervas 2009). Tectonic processes may either reduce or increase local relative sea level rise to various degrees across locations (Mote et al. 2008). Tectonic activity is regionally important on the western coast of the United States (Barber 2014; Mote et al. 2008), which is the most tectonically active part of the nation. Isostatic rebound tends to counteract sea level rise and is most prevalent in Alaska and the northernmost parts of Washington State (Barber 2014; Mote et al. 2008), though there is also evidence that relative sea level rates along the Atlantic coast are affected by isostatic adjustments due to the loss of the Laurentide Ice Sheet and ice sheets in Greenland (Engelhart et al. 2009).

\subsubsection{Subsidence}

Subsidence is the compaction of unconsolidated sediments into a smaller volume, either due to the removal of water, weight of overlying sediments, or subsurface extraction of groundwater or oil (Day et al. 1995; Nicholls 2003). Compaction by de-watering and additional weight of overlying sediments is a naturally occurring process, although anthropogenic land use changes can impact the rates of these processes beyond what is natural (Belperio 1993), such as when diking de-waters areas with former tidal 
influence and causes accelerated subsidence. Subsurface hydrocarbon or groundwater withdrawal is an anthropogenic source of marsh subsidence (Belperio 1993; Kolker et al. 2011; Turner 1997). These processes reduce pore water pressure between sediments and cause compaction (Ericson et al. 2006). Subsidence is one cause of marsh elevation loss and can be offset by sediment deposition on the marsh surface, although this additional loading may result in significant additional consolidation, which must be taken into account.

\subsubsection{Sediment supply}

Mineral sediment deposition directly contributes to increasing marsh elevation by adding sediment volume (Mendelssohn and Kuhn 2003) and contributes to bulk density, which helps the salt marsh to keep pace with sea level rise through the accumulation of inorganic matter. Sediment supply to coastal areas has diminished nationwide because of anthropogenic activities including reforestation, urbanization, agricultural sediment-control, dam construction (Kirwan et al. 2010), and levee construction (Day et al. 2007). Reforestation, agricultural sediment control, and urbanization reduce the contribution of sediment through erosion control (Weston 2014). Dams prevent natural sediment transport in streams and rivers, preventing the sediment from nourishing marshes at the coasts and in lower, tidal reaches of rivers (Blum and Roberts 2009), and mainstem levees of major rivers shunt sediments to the open ocean rather than letting them distribute across adjacent marshes (Day et al. 2005).

These interruptions in sediment supply to the coast in some locations reduce the capacity of marshes to aggrade both vertically and horizontally in response to subsidence and global sea level rise (Kirwan et al. 2010; Mariotti and Fagherazzi 2013; Mudd 2011; Turner 1997). Ravens et al. (2009) found that in Galveston Bay, marsh loss was primarily due to insufficient sediment accretion rather than wave-induced erosion, subsidence, or global sea level rise. This led to the conclusion that restoration efforts in this area should concentrate on sediment supply rather than wave protection. 


\subsection{Incorporating geologic, regional, and local variations into relative sea level rise estimates}

Most variation in relative sea level rise is due to dynamic land changes and other local factors rather than eustatic sea level rise (Milne et al. 2009). For example, tectonic activity can have varying effects near plate boundaries in California, Oregon, Washington, and Alaska (Zervas 2009). In addition, El Niño Southern Oscillation or the Pacific Decadal Oscillation can exacerbate or suppress relative sea level rise on the Pacific coast (Bromirski et al. 2011; Mote et al. 2008; Sweet et al. 2014). Similar effects on the east coast are observed due to changes in the Gulf Stream. Mass redistributions change gravity and the earth's rotation and shape, which impacts both relative sea level and the intensity of storms (Ezer and Atkinson 2014; Ezer et al. 2013; Nicholls 2003; Sallenger et al. 2012). In Texas and Louisiana, subsidence by fluid withdrawal is the primary factor contributing to relative sea level rise (Kolker et al. 2011). Significant declines in riverine suspended sediment concentrations have been observed in rivers draining to eastern and Gulf of Mexico U.S. coastlines (Weston 2014). High-magnitude storm events such as hurricanes or El Niño events can locally affect coastal wetland soil elevations by substrate redistribution, vegetation death, erosion by rain and storm surge, or delivery of large quantities of sediment (Cahoon 2006). Local and regional changes in climate, including shifts in rainfall patterns or changes in watersheds under different climate scenarios, may also have an impact and must be considered when estimating relative sea level rise (Callaway et al. 2007).

Hall et al. 2016 developed adjustments to five global sea level rise scenarios (start year: 1992, and global SLR range by 2100: $0.2-2.0 \mathrm{~m}$ ) for future projections to address site-specific conditions. Adjustments to Hall's sea level rise scenarios consider local vertical land movement, dynamical sea level, and ice melt from glaciers and ice sheets. The results from these projections show that one or more of the three adjustments can result in significant contributions to site-specific sea level changes. The USACE regulations and guidance (USACE 2013, 2014) that address sea level change requirements for Civil Works related projects require consideration of local vertical land movement only and do not require additional adjustments. The USACE advises against using sea level records shorter than 40 years with 50 to 60 years preferred for estimates of local sea level trends. 


\section{Impacts of Relative Sea Level Rise on Salt Marshes}

The following section describes how relative sea level rise impacts salt marshes by de-coupling ecogeomorphic feedback processes. Under normal circumstances, marsh elevation affects vegetation growth and establishment, thereby hindering erosion and mediating sedimentation. These feedbacks work together to preserve marsh elevations within the intertidal zone that is required by the prevalent marsh species (Blum 1993; Broome and Craft 2009; Day et al. 2008; Friedrichs and Perry 2001; Hackney and Cleary 1987; Kirwan and Temmerman 2009; Kirwan et al. 2010; Kirwan and Guntenspergen 2012; Morris et al. 2002). As relative sea level accelerates to rates that these processes cannot keep up with, decoupling occurs that cause marsh degradation.

\subsection{Marsh elevation change}

The long-term sustainability of salt marshes is dependent on maintenance of marsh elevation within an optimum elevation range required by the species dominating the marsh (Craft et al. 1993; Kirwan and Megonigal 2013; Reed 1995). The rate of marsh surface accretion must, therefore, keep pace with sea level rise and subsidence or the marsh will become excessively inundated, leading to a cascade of ecological effects (e.g., inundation leading to plant stress and die off, leading to additional subsidence as below-ground biomass decomposes and sediment trapping by above-ground biomass is reduced, leading to more vegetation stress and die off; Orr et al. [2003]). The optimum marsh elevation is maintained by organic matter contributions from vegetation, root growth or decomposition, sediment deposition or erosion, compaction, and other related surface and subsurface processes (Baustian and Mendelssohn 2015; Cahoon et al. 1995; Cahoon et al. 1999; Cahoon 2006; Cahoon et al. 2006; Christiansen et al. 1999; Kirwan and Guntenspergen 2012; Mudd et al. 2009).

Rates of sediment accumulation vary extensively around the United States and are predicted in part by tidal range (Stevenson et al. 1986). Tidal channels facilitate the delivery of sediments and nutrients to the back marsh, influencing sediment transport (Fagherazzi and Priestas 2010; French and Stoddard 1992; Lawrence et al. 2004; Roman et al. 1997; Stumpf 1983; Temmerman et al. 2003), and the delivery of sediments and nutrients can vary widely with storm events, wind direction, available 
suspended sediment (Reed 1989; Turner et al. 2006), and tidal range (McCall and Pennings 2012).

Salinity changes can affect root decomposition rates, accelerating loss of organics in the soil and promoting subsidence (Craft 2007; Day and Templet 1989). When marsh elevation is not maintained by these processes, excessive inundation caused by sea level rise or diminished sediment deposition leads to increased soil anaerobiosis and the accumulation of phytotoxic hydrogen sulfide (Mendelssohn and McKee 1988). Ultimately, vegetation productivity is limited, causing reduced elevation gains by organic matter contributions, further exacerbating the problem (DeLaune et al. 1990). If vegetation becomes sparse enough, even the accumulation of mineral sediments is diminished by the lack of roughness (Baustian et al. 2012; Day et al. 1995), and flooded ponds can develop and expand within the marsh plane (Hartig et al. 2002). Marshes that are particularly vulnerable to excessive inundation occur in areas where the marsh exists in the lower intertidal elevation zone or in areas with high rates of relative sea level rise (Kirwan and Megonigal 2013).

\subsection{Vegetation impacts}

Relative sea level rise impacts salt marsh vegetation primarily through the effects of excessive inundation (Callaway et al. 2007). Excessive inundation of vegetation causes a reduction in soil aeration and production of phytotoxic hydrogen sulfide (Slocum et al. 2005). Extended anaerobic conditions reduce vegetation growth because roots are forced to use less efficient anaerobic metabolism (Graham and Mendelssohn 2013; Linthurst and Seneca 1979; Mendelssohn and McKee 1988; Mendelssohn and Seneca 1980). Extended anaerobic conditions can also cause shifts in species dominance (Davy et al. 2011; Offl et al. 1997; Orson et al. 1998; Warren and Niering 1993) and result in significant production of hydrogen sulfide by anaerobic microbial metabolism (Mendelssohn and McKee 1988). Hydrogen sulfide inhibits metabolic processes, in particular the uptake of ammonium (Schrift et al. 2008). Ultimately, factors associated with excessive inundation can result in the death of the vegetation and loss of ecological functions associated with marsh vegetation (Stagg and Mendelssohn 2010; Day et al. 2011). 


\subsection{Accelerated erosion}

Higher water levels degrade the surface and edges of coastal marshes due to erosional impacts. Shallow intertidal marshes are particularly vulnerable to erosion by increased water depth, as deeper water does not allow for the dissipation of energy as waves move across tidal flats (Kirwan and Megonigal 2013; Mariotti and Fagherazzi 2013; Slocum et al. 2005). The marsh surface is eroded by wind-wave re-suspension of exposed sediments (Ganju et al. 2015). Decreased roughness of the marsh plain caused by lack of vegetation exacerbates erosion by wave action across the marsh plain (Baustian et al. 2012). Increased wave energy from higher water levels also causes erosion of the marsh edges (Heberger et al. 2009; Reed 2002). Though conventional wisdom indicates that shore erosion, like marsh plain erosion, is mitigated by plant density, Feagin et al. (2009) found that soil type and condition rather than vegetation presence was a better indicator of shoreward marsh edges susceptibility to wave erosion. Coverdale et al. (2014) found that weakened peat allowed for greater crab burrowing, which degraded peat soils further and led to bank caving. This caused not only the loss of marsh area but the rapid loss of carbon that had been sequestered in marsh soils over the previous two centuries. Erosion of both the marsh surface and the edge can result in export of sediment and carbon from the system (Ganju et al. 2015). 


\section{Management Opportunities}

Coastal salt marshes are susceptible to degradation by abiotic and biotic interactions including relative sea level rise. In most cases, direct management of relative sea level rise itself is not possible. Management efforts to reduce impacts of relative sea level rise on salt marshes have focused on abiotic factors that will in turn facilitate biotic responses. The following sections describe the management methods identified in the literature used to determine the appropriate restoration technique or combination of techniques to ameliorate salt marsh degradation due to relative sea level rise (Teal and Weishar 2005; US FWS 2014a,b; Wigand et al. 2015). The management method includes the following steps:

1. Identify the characteristics (symptoms) of marsh degradation and characterize via metrics and analysis.

2. Link the symptoms of degradation to stressors affecting relative sea level rise and identify appropriate restoration measures.

3. Develop a comprehensive restoration strategy for adapting to relative sea level rise utilizing the selected measures.

4. Evaluate and monitor marsh response to the restoration technique and adaptively manage the response.

This management process, as a complete process, has been identified and utilized by restoration projects in California, Rhode Island, New Jersey, and Delaware (US FWS 2014a,b; Teal and Weishar 2005; Wigand et al. 2015).

\subsection{Identify the characteristics (symptoms) of marsh degradation}

This section summarizes approaches described in the literature that have been used to identify degraded salt marshes. Many of the metrics described in this section for assessing the current condition of marshes may also be used in monitoring restoration and adaptive management and may also be described in those sections of this report.

Identifying impacted marshes requires adequate assessment of past and present conditions, as well as ongoing monitoring to assess trends indicative of a stressed system. Three broad approaches were identified to assess the condition of salt marshes: computer-based assessments, field- 
based ecological assessments, and geomorphic and physical processes assessments. Each of these approaches is described in detail below.

\subsubsection{Computer-based assessments}

Three computer-based methods were identified to classify impacted or potentially impacted marshes: (1) use of digitized historic aerial photographs, (2) geographic information systems (GIS), and (3) computational models. Impacted or threatened marshes have been identified using a series of historical photographs to detect trends in vegetation coverage, shoreline erosion, channel erosion, increased frequency of pools and pannes, and tidal channel widening (Erwin et al. 2004; Hartig et al. 2002; Hinkle and Mitsch 2005; Wigand et al. 2015). GIS has also been used to identify suitable locations for restoration by incorporating digitized data such as land type and use, hydrology, and soil type (Borde 2004; Erwin et al. 2004). Computational models are used to identify vulnerable salt marshes, and there are a number currently in use for this purpose. The most widely used computational models are described below and summarized in Table 1 .

The most common computational model used in the literature was the Sea Level Affecting Marshes Model (SLAMM), which combines recent vegetation, accretion, and elevation data to identify areas that may become permanently inundated, as well as upland areas that may transition to wetlands under several sea level rise scenarios (Craft et al. 2008; Glick et al. 2013; Wigand et al. 2015). SLAMM offers the advantage of being widely used and allowing comparisons of multiple sites. It has evolved over the years to address complexities that the original model did not consider and has been favorably evaluated and shown to be consistent with other models (Wu et al. 2015).

More detailed linked ecological and geomorphic process-oriented models have also been developed in limited geographic regions. These allow for scenario testing given a range of sea level rise estimates and sediment concentrations (Kirwan and Murray 2007; Martin et al. 2002; Stralberg et al. 2011; Schile et al. 2014; Temmerman et al. 2004; Van Wijnen and Bakker 2000) as well as vertical marsh growth numerical models (French 1993). Even though these models were applied to a specific region, their basis could be used for evaluating coastal marshes in other regions. Fagherazzi et al. (2012) discuss in detail multiple conceptual, physical, empirical, and numerical models that have been used to simulate fluxes of 
water, organic matter, and sediments in salt marshes, and to determine salt marsh survival under different scenarios of sea level rise. The model presented in Morris et al. (2002) predicts a rate of relative sea level rise for estuaries in the southeastern United States at which the equilibrium elevation and depth of tidal flooding will be ideal for plant growth and is used to determine whether or not a marsh is stable. French (2006) developed a numerical model for mass balance based on the parameter space defined by marsh elevation, sedimentation, sea level rise, sediment supply, and tidal range that provides insights into marsh morphodynamic behavior. Stralberg et al. (2011) developed a hybrid approach involving mechanistic treatment of marsh accretion dynamics and spatial variation at a scale relevant for restoration. The model uses elevation data, sediment supply, and organic matter accumulation. Salt marsh hydrology and flow restrictions were assessed using analog, empirical, mathematical, and physical models by MacBroom and Schiff (2012). Analog and empirical models are used for small projects with site constraints and environmental risk limitations to initiate design. Mathematical models are typically used for evaluating marsh hydraulics (Table 1).

In several cases, a combination of computer-based methods was used to identify impacted or potentially impacted salt marshes, allowing corroboration of several lines of evidence to detail impacts or potential impacts. For instance, Heberger et al. (2009) utilized digital elevation models and light detecting and ranging (LiDAR) in conjunction with GIS to determine tidal flooding risk. Weinstein et al. (2001) linked false color infrared digital orthophotography with GIS to assess changes in vegetation and geomorphic features over time compared to reference marshes.

\subsubsection{Ecological assessments}

In the literature, field-based ecological assessments examining marsh condition are mainly related to vegetation vigor or sensitive bird species (Wigand et al. 2015; US FWS 2014b), with limited soil metrics included in the assessments (Twohig and Stolt 2011). Bird species are surveyed for nesting habitat and frequency of inundation (Wigand et al. 2015; US FWS 2014b). Vegetation is generally surveyed for plant community and plant cover (Wigand et al. 2015). Both of these have the advantage of being relatively easy to collect but respond only after ecological stressors are fairly advanced. Leaf tissue chemistry was used in one case to identify degraded marshes (Tobias et al. 2010) by identifying salinity stress and nutrient limitations that reduce primary productivity. This has the 
advantage of being an early indicator but was only calibrated for Spartina patens and so is not applicable to all marshes.

Soil assessment methods are less developed, and less often measured, because of the spatially heterogeneous nature of soils (Twohig and Stolt 2011). However, several studies have attempted to develop soil assessment metrics with varying success. In two studies, soil strength using bearing capacity was used as a soil assessment metric to assess physical degradation of the marsh (Twohig and Stolt 2011; Wigand et al. 2015). Additional soil properties used to assess impacted marshes were pore water salinity (Wigand et al. 2015), soil morphology, stable plant fragment content, and pH (Twohig and Stolt 2011). Two recent metrics used were the difference in flood/ebb suspended sediment concentration and the organic/inorganic ratio of the suspended sediment to evaluate loss of organic marsh substrate from a system (Ganju et al. 2015).

Rapid assessments were utilized to assess marsh condition in two studies (Twohig and Stolt 2011; Wigand et al. 2015). Rapid assessment metrics included areal extent of dieback in the high marsh area, vegetation composition, and soil bearing strength (Wigand et al. 2015). Specific soil rapid assessment metrics were identified and tested by Twohig and Stolt (2011). The soil rapid assessment metrics utilized were soil morphology, stable plant fragment, bearing capacity, and soil $\mathrm{pH}$ (Twohig and Stolt 2011). These metrics were applied to two marshes in Massachusetts and Rhode Island to identify differences in degraded and reference salt marshes.

Evaluation of marsh conditions using soil metrics is restricted at this point. There is a lack of consistency in the metrics used; the soil metrics are not easily measurable, the methods are complicated, and the metrics do not effectively detect changes in marsh condition (Twohig and Stolt 2011). Vegetation and soils were only assessed at the same time in one instance (Wigand et al. 2015), demonstrating the need to incorporate vegetation and soil metrics to assess marsh conditions. Additional paired studies are needed to validate soil metrics for assessing marsh conditions.

\subsubsection{Field assessments for geomorphic and physical processes}

Assessments generally include evaluation of hydrology, geomorphology, physical processes, and elevation. Hydrologic assessments identify tide elevations, water surface elevations, flow velocity, discharge rates, freshwater sources, tidal restrictions due to structures, channel cross- 
sections, tidal prism, tidal cycling, freshwater inflows, marsh water budget, or flow types (MacBroom and Schiff 2012). Geomorphic assessments are performed to identify channel patterns, mosquito ditch networks, channel substrate types and erosion thresholds, channel bank heights and stability, the extent of active floodplain, ebb or flood tide sediment bars, deltas, shoals, mud flats, and evidence of erosion or deposition (MacBroom and Schiff 2012). Physical parameters such as temperature, conductivity, turbidity, total suspended solids, and salinity are used to evaluate water quality. Turbidity and total suspended solids are also measured to estimate sediment storage and transport (MacBroom and Schiff 2012).

Accretion, elevation trajectories of marshes relative to local sea level rise, and influence of subsurface processes on elevation change can be assessed using Surface Elevation Tables (SETs), which measure the change in sediment elevation over time (Cahoon et al. 2002a). Marker horizons (MHs) are used to measure material deposition on top of the placed MH. SETs used in conjunction with MHs (SETs-MHs) are used to determine shallow subsidence (Cahoon et al. 1995). This method was specifically developed for use in marshes and incorporates simultaneous measurements of wetland elevation from an SET and vertical accretion from an artificial MH (Boumans and Day 1993; Cahoon et al. 2002a,b; Cahoon and Turner 1989). An informal SETs-MH monitoring network that allows for a quantitative comparative assessment of marsh response to current sea level rise across sites and key processes controlling submergence or survival was developed during the past 15 years using data collected from stations located in Europe, North America, the Caribbean, and western Pacific (Cahoon et al. 2006). Rod Surface-SETs were developed to complement SETs and increase precision of sediment elevation measurements, changes in sediment elevation at shallower and deeper depths than SETs can be quantified (Cahoon et al. 2002b). The Rod Surface-Elevation Table-Marker Horizon (RSETs-MH) method was developed to account for wetland surface and shallow subsurface processes after the SETs-MH method was developed (Webb et al. 2013). The RSETs-MH provides precise and easily replicable data, improves data interpretation, and can be upscaled through modeling if integrated with existing mapping technologies that are not spatially limited (e.g., d/RTKGPS, surveying and LiDAR; Webb et al. [2013]). Other methodologies used for measuring wetland surface elevation include Real Time Kinematic-GPS (d/RTK-GPS), total station, LiDAR, Advanced Spaceborne Thermal 
Emission and Reflection Radiometer, and Shuttle Radar Topography Mission. All these methodologies have significant differences in vertical accuracy, spatial resolution, spatial coverage and replicability, and cost. In only one study, high-quality elevation data obtained through LiDAR were used to identify and delineate salt marshes vulnerable to sea level rise (Gesch 2009). Radiometric techniques are used to estimate soil accumulation rates over longer time periods using radioisotopes such as ${ }^{137 \mathrm{Cs}}$ (30-50 years) or ${ }^{210} \mathrm{~Pb}$ (50-100 years; Donnelly and Bertness [2001]; Orson et al. [1998]; Roman et al. [1997]).

SETs-MH data, water levels, marsh drainage patterns, marsh elevation, accretion, and elevation changes were measured at Jamaica Bay in New York, Narrow River in Rhode Island, and the Mississippi Delta in Louisiana salt marshes to determine accretion and elevation dynamics of salt marshes in these areas (NPS 2004; Wigand et al. 2015; Day et al. 2011). For Jamaica Bay, SETs-MH were used to compare elevation dynamics between a stable and a deteriorating marsh. The deteriorating marsh showed a higher rate of accretion but lower rate of elevation gain, which is typical of deteriorating marshes located lower within the tidal range (NPS 2004). Isotopes ${ }^{210} \mathrm{~Pb}$-derived accretion rates were only determined in one instance (Jamaica Bay), which were used in a detailed analysis of a model to indicate whether or not marsh losses were linked to sediment accretion (NPS 2004). Radioisotope tracers were also used in Jamaica Bay to determine sediment transport pathways in space and time based on physical circulation (NPS 2004). For two studies, sedimentation and suspended sediment concentrations were assessed using surface sediment traps and water samplers, respectively (Day et al. 2011; Reed et al. 1999). Reed et al. 1999 determined hydroperiod parameters (duration and depth of flooding) and the amount of suspended sediment moving across the marsh surface to show transport behavior between tidal cycles and between flood and ebb tides.

Other types of geomorphic and physical process assessments that were used in the literature are discussed below. A sediment mass balance was used in one instance to determine sediment supply projections based on different sea level rise rates (Blum and Roberts 2009; Mariotti and Fagherazzi 2013). French (2006) estimated sediment supply and its depletion due to deposition for assessing marsh resilience. A simple way to determine the capacity of a salt marsh to adapt to current sea level rise trends is to compare rates of relative sea level rise to marsh accretion 
rates; if the accretion rate is smaller than the sea level rise rate, then the marsh is unable to adapt to sea level trends, and restoration should be considered (US FWS 2014a). A way of determining if a salt marsh is migrating landward as sea level rises is to evaluate trends upstream of the tidal prism and channel cross section. Increasing trends in the upstream tidal prism and growth of channel cross section indicate a marsh is spreading landward due to sea level rise (Friedrichs and Perry 2001). Increased flooding associated with accelerating rates of sea level rise has stressed high-marsh communities and promoted landward migration of cordgrass (Donnelly and Bertness 2001). A decline in marsh areal extent due to sea level rise is reflected by a decrease in the tidal asymmetry factor (Friedrichs and Perry 2001).

\subsubsection{Combining field and computer model assessments to identify the factors contributing to marsh impacts}

Salt marsh degradation is a result of complex interactions between a number of factors acting at different spatial and temporal scales (Boesch et al. 1994; Day and Templet 1989; Day et al. 1995; Day et al. 1997; Turner and Cahoon 1987). All possible factors related to marsh degradation must be considered since multiple factors may have a compounded effect or can be synergistic (Hartig et al. 2002; Hine 2015; O’Neill 2015). Identifying the role of each factor could be very challenging, but it is key to understanding ecosystem response and to developing appropriate restoration strategies, modeling, monitoring, and adaptive management (NPS 2004).

Salt marsh restoration projects identified factors contributing to marsh degradation using a combination of computer-based methods, field-based ecological methods, and engineering methods (Hartig et al. 2002; US FWS 2014a,b; Wigand et al. 2015). Assessing the interlinked ecological and physical marsh processes allowed identification of the underlying causes of marsh degradation. For example, a combination of historical aerial photography, marsh accretion rates and erosion, plant community distribution, and vegetation biomass measurements was used to assess marsh degradation in Jamaica Bay, NY (Hartig et al. 2002). Using these multiple lines of evidence, relative sea level rise and sediment starvation were identified as possible main factors contributing to waterlogging, vegetation death, and erosion. Narrow River, RI, utilized the SLAMM model, historical photography, and assessment of soil and vegetation parameters to examine current marsh conditions and future 
vulnerabilities to sea level rise (Wigand et al. 2015). These assessments identified areas of increased erosion, low elevation, vegetation die off, and excessive ponding, which allowed restoration techniques to be targeted to specific areas based on the identified marsh degradation process (US FWS 2014a; Wigand et al., 2015). In California, d/RTK-GPS and surveys of two endangered bird species were used to assess the marsh and determine that subsidence and sediment supply were the main causes of marsh degradation (US FWS 2014b).

In addition to using a combination of computer-based methods, field-based ecological methods, and engineering methods, tools that can account for the interaction of multiple factors across extended temporal and spatial scales (landscape models) are being developed. Martin et al. (2002) describe three landscape models being used in the Mississippi deltaic plain, which link hydrodynamics, soils, and ecological assessments to predict changes in marsh habitat cover gains and losses associated with scenarios accounting for changes to riverine inputs, accelerated sea level rise, and a suite of proposed management plans. In Lake Erie, aerial photographs, GIS, and paleological and sedimentological analysis were used in conjunction to determine factors contributing to degradation of wetlands (Borde et al. 2004).

\subsection{Linking the symptoms of marsh degradation to appropriate restoration measures}

Once a suite of metrics have been used to document marsh degradation, the likely stressors become apparent. For example, isolation from a watershed often leads to a decrease in sediment supply or regional extraction of groundwater leads to subsidence and vegetation stress. Once these stressors are identified for a specific marsh, the appropriate restoration techniques can be considered. Below, an array of restoration techniques are linked to stressors and catergorized based on restoration strategy.

More than 50 documents relating to techniques for the restoration of salt marshes with respect to relative sea level rise are included in the current literature review. References were obtained primarily by searching each restoration technique name and other key words (Appendix A) in conjunction with sea level rise. Table 2 lists each of these references and identifies the relative sea level rise observed, location of the study, and the restoration techniques considered or employed. If the study employed monitoring or adaptive management metrics or techniques, those are also 
identified. Appendix B provides the citations and abstracts for all references in Table 2, as well as other references that provide relevant information but are indirectly tied to restoration techniques.

The restoration techniques reviewed were broadly categorized into four classes based on restoration strategies and typical salt marsh stessors, including hydrology, sediment supply, erosion, or coastal squeeze. The restoration strategies were categorized as follows: (1) hydrologic restoration, (2) sediment re-supply, (3) erosion reduction, and (4) inland migration. A brief summary detailing the major salt marsh restoration techniques within each category is presented below. Marsh response is then linked to restoration generally (Figure 1) and specifically for each restoration technique.

\subsubsection{Hydrologic restoration}

\subsubsection{Modification of hydrologic obstruction: levee, dikes, or culverts}

Several papers address situations in which man-made dikes or mis-sized culverts merely reduce tidal prisms rather than remove them altogether (Konisky et al. 2006; Warren et al. 2002; Weinstein et al. 2001), causing stress to the existing marsh, which can then be exacerbated by sea level rise. In these cases, the lack of tidal exchange typically allows freshwater inputs too much influence, causing decreases in salinity, increased residence time, vegetation conversion, and in some cases, subsidence. Removing the barriers to tidal exchange facilitated a return of salt marsh species through improved hydroperiod and salinity (Konisky et al. 2006; Warren et al. 2002; Weinstein et al. 2001).

A second scenario for dike/levee breaches restoring hydrology to salt marshes occurs when the dikes or levees on rivers have restricted sediments and nutrients from entering saltmarshes. This has particularly been an issue on the mainstem levee of the Mississippi River, which has effectively starved thousands of acres of marsh from freshwater, nutrients, and sediment within coastal Lousiana (Zedler and Kercher 2005). Several breaches in the Mississippi River levees allow small diversions to restore sediment transport into the marshes of coastal Louisiana and may be equally important for controlling salinity (Day et al. 2005). There are concerns that these diversions will cause over freshening, shifts in fisheries locations, and potential water quality issues. However, using larger 
infrequent diversions rather than smaller continuous ones may minimize these concerns (Day et al. 2016).

In most cases, the purpose of removing part (breaching) or all of a levee or dike is to increase the tidal exchange within the marsh. This technique is most often applied in restorations of previous marshes that were historically converted by diking to other land uses - where the dike being breached is the one that caused the conversion in the first place - rather than in existing marshes that are being degraded by relative sea level rise (Cornu and Sadro 2002; Eertman et al. 2002; Weishar et al. 2005). Levee or dike breaching/removing is particularly active in the New England coast and California because of the long history of salt marsh diking and drainage for agriculture, salt production, and mosquito control. While these examples are important to general restoration and sea level rise adaptation literature, they do not specifically address the challenge of maintaining existing coastal salt marsh function in light of sea level rise.

\subsubsection{Creation of runnels/creeks}

Marsh channels are created by re-excavation or artificially digging runnels or creeks. The establishment of marsh channel systems supports marsh drainage and tidal exchange (Wigand et al. 2015). Wigand et al. (2015) reported excavation depths and widths for runnels varying between 0.2 to $0.5 \mathrm{~m}$ depth and 0.15 to $0.5 \mathrm{~m}$ wide and creeks at $0.5 \mathrm{~m}$ deep and $1 \mathrm{~m}$ wide). Additional benefits include dissipation of tidal energy, efficient sediment delivery (Reed et al. 1999), improved water quality, and creation of fish and bird habitat (Zedler 2000). Seven references used runnel or creek creation as the major restoration technique for salt marshes (Dale 2007; Eertman et al. 2002; Koo et al. 2011; Reed et al. 1999; Teal and Weishar 2005; Weinstein et al. 2001; Weishar et al. 2005). Three additional references utilized runnel/creek creation in conjunction with other restoration techniques (Haltiner et al. 1997; Teal and Weinstein 2002; Wigand et al. 2015). Locations where runnels or creeks were reexcavated or artificially dug were Connecticut, New Jersey, Delaware, California, United Kingdom, The Netherlands, Korea, and Australia.

The construction of marsh runnels and creeks increased tidal range to the marsh by $1 \mathrm{~m}$ in comparison to pre-construction tidal ranges at the Scheldt Estuary in The Netherlands (Eertman et al. 2002). The sedimentation rate during the first 3 years following construction was twice as high (3 centimeters year-1 $\left.\left[\mathrm{cm} \mathrm{yr}^{-1}\right]\right)$ versus reference marshes in the same areas 
(1.5 $\mathrm{cm} \mathrm{yr}^{-1} ;$ Eertman et al. [2002]). The use of runnel/creek creation in conjunction with levee or dike breaching improved tidal exchange, reduced water velocity across the marsh, increased sediment deposition (Weishar et al. 2005), and improved fish habitat (Teal and Weinstein 2002; Zedler and Kercher 2005). Teal and Weishar (2005) identified a positive restoration trajectory as normal tidal flow was achieved within 3 years and $45 \%$ vegetation coverage with desirable species within 7 years with the inclusion of channel restoration. These restoration trajectories were also achieved at Scheldt Estuary in The Netherlands following construction of a marsh creek (Eertman et al. 2002).

\subsubsection{Sediment re-supply}

\subsubsection{Thin layer placement}

Thin layer placement is the application of dredged material or similar sediments to the surface of the marsh (Palermo and Dardeau 1994). The purpose of the added sediment is to raise the marsh elevation to promote vegetation growth (Borde et al. 2004). Generally, thicknesses of dredged material ranging from 10 to $30 \mathrm{~cm}$ were reported in the literature. Thin layer placement of dredge material was used as the major restoration technique in ten references: Cahoon and Cowan (1987); Cornu and Sadro (2002); Croft et al. (2006); DeLaune et al. (1990); Ford et al. (1999); Mendelssohn and Kuhn (2003); Ray (2007); Schrift et al. (2008); Wigand et al. (2015); Wilber (1993). Locations where thin layer placement have occurred in salt marshes include Rhode Island, Connecticut, North Carolina, Louisiana, and Oregon. Hartig et al. (2002) suggest thin layer placement as a management option in New York marshes.

Reports in the literature indicate that thin layer placement of dredged material can increase marsh elevation (Titus 1988), reduce anaerobic conditions in the upper soil layers (Mendelssohn and Kuhn 2003), and stimulate vegetation growth (Cornu and Sadro 2002; DeLaune et al. 1990; Schrift et al. 2008). Re-vegetation of the marsh via rhizomes occurred at sediment slurry additions less than $30 \mathrm{~cm}$ (Ford et al. 1999; Schrift et al. 2008). There is evidence that some species, such as Spartina alterniflora, respond vigorously to burial via rhizomatous growth (Deng et al. 2008), implying that placement of even thicker sediment layers over living plants may serve as a management technique to encourage vegetation growth. The long-term benefit of dredged material additions to a marsh is unclear, as data beyond 2 to 3 years are generally lacking. 


\subsubsection{Nearshore placement}

Nearshore placement is dredged material placement in the littoral zone. The placement of dredged material in the littoral zone facilitates sediment deposition or feeding of nearby marshes as a technique to increase marsh elevation. Two references described nearshore sediment placement as a marsh restoration technique (Heilman et al. 2007; Wilson and Prickett 1998). Locations where nearshore placement has taken place are Florida, Louisiana, and Texas. Additionally, Lowe and Bourgeois (2015) describe nearshore placement as a potential management option in California.

Nearshore placement of dredged material is a relatively new idea for sustaining marsh accretion and uses principles from nearshore placement for beach nourishment (Wilson et al. 1998). Previous studies have focused on the engineering and stabilization of sediment during nearshore placement rather than the response of marshes expected to potentially receive sediment (Heilman et al. 2007; Wilson et al. 1998). Active research and management considerations for nearshore placement are currently taking place in California; however, no data are available to report effectiveness of this restoration technique (Lowe and Bourgeois, 2015).

\subsubsection{Removal of inland dams}

Dams upstream of marsh systems trap sediment. The removal of inland dams increases the suspended sediment loads in creeks and rivers discharging into the marsh systems (Wigand et al. 2015). In many cases, dams are semi-permanent landscape features because of water supply, hydropower, navigation, or recreational purposes and therefore are unlikely to be removed (Simenstad et al. 2006). As a result, there were no references that used removal of inland dams as the major salt marsh restoration technique with respect to sea level rise.

Removal of inland dams has not been considered a viable sea level rise restoration technique for salt marshes at this time. However, dam removal has occurred as part of ecosystem restoration (Zhao et al. 2016) and is increasingly planned around the world. As sediment availability increasingly constrains salt marsh restoration in the face of sea level rise, removal of inland dams may become an important restoration technique (Simenstad et al. 2006). 


\subsubsection{Erosion reduction}

\subsubsection{Living shoreline}

Living shorelines use plants or other natural elements, sometimes in concert with hard-engineered structures, to stabilize estuarine coasts, bays, or tributaries (NOAA 2015). Living shoreline approaches can be used across a range of shore habitats, from subtidal oyster reefs and submerged aquatic vegetation to marshes to upland transitions and dunes. A subset of those approaches are appropriate for marsh stabilization and maintenance of function in marshes subjected to sea level rise. Specifically, biomaterials, (e.g., oyster shells, vegetation, or coconut fiber [coir] logs) may be used to stabilize and protect the marsh edge from erosion (Lowe and Bourgeois 2015; Wigand et al. 2015).

Living shorelines dissipate wave action and enhance sediment deposition on the marsh. Living shoreline was cited as the primary sea level rise restoration technique in four references (Currin et al. 2010; Piazza et al. 2005; Walker et al. 2011; Wigand et al. 2015) in New York, Maryland, Virginia, North Carolina, and Louisiana. In addition, California is considering use of living shorelines as a management technique for sea level rise (Lowe and Bourgeois 2015). However, many of these techniques have been tried around the country for many years outside the context of sea level rise, and many states (e.g., New Jersey) have guidance incorporating these techniques into Coastal Zone Management rules.

Living shoreline as a restoration technique can be broadly defined as a protected and stabilized shoreline that is made of natural materials and can be used to buffer upland, coastal marshes, and subtidal zones (NOAA, https://www.fisheries.noaa.gov/insight/living-shorelines); a choice was made to focus on living shorelines designed for stabilizing marshes specifically. Use of a living shoreline reduced shoreline retreat (Piazza et al. 2005) and increased sedimentation rates (Currin et al. 2010) and thus has the potential to provide shoreline stabilization to marshes experiencing edge erosion (Lowe and Bourgeois 2015). Added benefits of using living shorelines are potential habitat creation and improved water quality (Walker et al. 2011). Living shorelines perform best in low- to medium-energy environments (Piazza et al. 2005). 


\subsubsection{Marsh terracing}

Marsh terracing is the process of creating emergent marsh by excavating subtidal bottom sediments and shaping the sediments into elongated or circular structures (Armitage et al. 2014; Zedler and Kercher 2005). Marsh terracing reduces wave energy and erosion, enhances sedimentation, and provides submerged habitat for fish (Borde et al. 2004; Feagin and $\mathrm{Wu}$ 2006). Four references described the use of marsh terracing for salt marsh restoration in response to sea level rise (Armitage et al. 2014; Feagin and Wu 2006; Rozas and Minello 2001; Rozas et al. 2005). Examples of marsh terracing were found in Texas and Louisiana.

Marsh terracing was reported to reduce fetch, wave energy, and shoreline erosion (Rozas and Minello 2001). It also increased sediment deposition (Feagin and $\mathrm{Wu}$ 2006) within terraced marsh ponds. However, the main focus of marsh terracing studies has been on habitat diversity and coastal fisheries (Feagin and Wu 2006; Rozas and Minello 2001; Ravens et al. 2009; Rozas et al. 2005). The potential for vertical or horizontal accretion or reduced erosion in tidal marshes located near established marsh terraces is recognized but has not been assessed at this time.

\subsubsection{Sediment fences}

Sediment fencing is a term applied to the building of an artificial fence within the tidal zone using recycled Christmas trees (Boumans et al. 1997) or bundles of vegetation/tree limbs (Koo et al. 2011; Scarton et al. 2000). The purpose of a sediment fence is to reduce wave energy and erosion and enhance sediment retention (Callaway et al. 2007; Day et al. 1995). Three references cited the use of sediment fences to restore salt marshes (Boumans et al. 1997; Koo et al. 2011; Scarton et al. 2000). Sediment fences have been used to enhance sedimentation to counteract relative sea level rise in Louisiana, Italy, and Korea. Practicioners in San Francisco Bay, CA, are considering use of sediment fences as a management technique to accelerate marsh accretion rates to keep pace with sea level rise (Lowe and Bourgeois 2015).

Sediment fences reduced wave energy by 50\% (Boumans et al. 1997) and enhanced deposition in response to reduced wave energy in low-energy environments (Boumans et al. 1997; Koo et al. 2011; Scarton et al. 2000). Sedimentation rates were one or more orders of magnitude higher in areas with fences than control areas $\left(1.78 \mathrm{~cm} \mathrm{yr}^{-1} \mathrm{vs} .0 .23 \mathrm{~cm} \mathrm{yr}^{-1}\right.$ and $2.5 \mathrm{~cm} \mathrm{yr}^{-1}$ 
vs. -0.3 cm/yr-1; Boumans et al. [1997]; Scarton et al. [2000], respectively). The increase in marsh elevation facilitated vegetation growth 3 years after installation of the sediment fences in areas $<5 \mathrm{~cm}$ below the surface of existing marshes (Boumans et al. 1997). A reduction in edge erosion was also observed (Scarton et al. 2000).

\subsubsection{Landward migration}

Landward migration is recognized as a restoration technique used to facilitate marsh migration inland, thereby providing a transitional zone for marsh expansion (Gedan et al. 2009). Inland migration studies have focused on prioritizing areas where landward migration potentially can occur or identifying priority areas for restoration because inland migration is not a viable option (Callaway et al. 2007; Day et al. 2008; Hartig et al. 2002). Landward migration requires preservation of open land or removal of barriers to migration, such as culverts or walls (Clausen et al. 2013; Wigand et al. 2015), which in many cases is not feasible (Hartig et al. 2002).

Landward migration was discussed as a possible restoration or adaptation technique in 10 references (Burkett and Kusler 2000; Craft et al. 2008; FitzGerald et al. 2008; Galbraith et al. 2002; Glick et al. 2013; Hughes 2004; Lowe and Bourgeois 2015; Moorhead and Brinson 1995; Pethick 1993, 2001). Landward migration has been modeled in conjunction with projects in North Carolina, Georgia, and California (Craft et al. 2008; Moorhead and Brinson 1995; Stralberg et al. 2011). In the United Kingdom, managed retreat of embankments has been discussed as a management option for migration of marshes inland (Pethick 1993, 2001). However, no data are available to assess the effectiveness of this adaptation technique.

\subsubsection{Ecological considerations}

The implementation of a salt marsh restoration technique often requires consideration of the ecological limitations for each restoration site. In particular, marsh restoration may require constraints on the time of year or locations for restoration actions. Potential impacts to consider are related to construction timing, turbidity moving offsite, or sediment grain size matching that of the target marsh. To avoid impacts to breeding or nesting birds, fish, or sea turtles, several restoration projects were restricted to certain non-breeding months for construction (US FWS 2014c; Wigand et al. 2015). In addition to restrictions on timing, impacts to fish, sea turtles, or 
sea grasses from turbidity associated with dredged material placement techniques were reduced by the installation of measures to prevent sediment moving offsite: vegetation buffers, silt fencing, silt curtains, etc. (US FWS 2014c). To address potential impacts to benthic organisms, sediments were tested for potential contamination, especially those that can bioaccumulate (e.g., lead, DDTs ${ }^{1}$, chlordane, and $\mathrm{PCBs}^{2}$ ), prior to placement of dredged materials (Heilman et al. 2007; US FWS 2014c).

\subsubsection{Engineering considerations}

Engineering constraints should be considered in combination with ecological limitations to implement salt marsh restoration techniques. The engineering considerations depend on site-specific conditions as well as the restoration technique chosen. Site-specific engineering factors include site geometry, hydrology, tidal parameters, geomorphology, hydrodynamics (wind, wave, and currents), sediment characteristics (e.g., sediment chemistry, sediment profile, pore water chemistry), and site restrictions (e.g., boating and navigation interests; Heilman et al. [2007], Wilson and Prickett [1998]). In addition to the site-specific engineering constraints, each restoration technique has specific engineering design considerations. For instance, living shorelines are appropriate in low- to medium-energy environments but not higher-energy environments because some nature-based features in higher-energy environments can wash out and reduce the successful establishment of the marsh community (Walker et al. 2011). Target elevations, sediment physical characteristics, and sediment consolidation need to be considered in determining best dredged material placement method, depth and location on site (Heilman et al. 2007) to ensure that the new marsh plain will be appropriate for the target plant species.

\subsection{Development of a comprehensive restoration strategy}

Recognizing that restoration projects often occur in isolation and neglect the broader landscape needs, Bowron et al. (2012) and Zedler (1996) recommend development of a restoration strategy for management of salt marshes affected by relative sea level rise at the local, regional, and national level. Understanding the environmental conditions that support and limit the distribution and abundance of the degraded habitats and

\footnotetext{
1 dichlorodiphenyltrichloroethane

2 polychlorinated biphenyl
} 
those targeted for re-establishment is required for a successful salt marsh restoration strategy on a regional or national level (Golet et al. 2012). A regional comprehensive baseline assessment with multiple metrics in ecology, soils, hydrology, geomorphology, and physical processes relevant to the restoration project could be used to accomplish this.

Only a few specific case studies (Rhode Island, Gulf of Maine, and California) have proposed the use of a restoration strategy for planning, managing, and implementing restoration actions in coastal marshes (Wigand et al. 2015; Zedler 1996; Hackney 2000). Climate change adaptation strategies, which have goals equal or similar to the ones that a restoration strategy encompasses, have been planned and implemented in a few more cases including Seal Beach, CA; San Francisco Bay; Egypt; and Europe (El-Raey et al. 1999; Hine 2015; Tol et al. 2008; US FWS 2014b,c). Restoration plans are commonly implemented on a project-specific basis; however, a synergistic and integrated strategic approach with a regional/landscape basis considering both climate and non-climate factors is needed for success of restoration projects (Borde et al. 2014; Elliot et al. 2000; Tol et al. 2008). For example, a site may have issues that require large-scale restoration strategies that will need a longer period of time for planning and design. However, the same site may have salt marshes under immediate threat that require short-term strategies for survival until large-scale restoration actions can be planned and implemented (Coastal Conservancy 2014).

\subsubsection{Establishing objectives and goals}

The degree of restoration success often depends on project-specific goals (Armitage et al. 2014). Restoration goals drive the design of the project and provide guidance for the development of performance criteria (Elliot et al. 2007; Thom and Wellman 1996; Weinstein et al. 2001). Similarly, the restoration goals and performance criteria provide the means for evaluation of the restored system (Thom 2000). Establishing clear project objectives should be part of the restoration plan (Thom 2000; Lewis 2000). Goals must be realistic and compatible with present and projected constraints associated with the spatial and temporal scale of the project and with ecological processes and methods (Kentula 2000; Cairns 2000). Primary goals established for projects published in the literature include re-establishing historical vegetation, restoring or enhancing habitat for wildlife and fish species, stabilizing shorelines, controlling mosquitoes, and restoring hydrology (Shreffler et al. 1995). A well-defined pre- 
restoration monitoring plan could be used to develop project goals if the existing ecosystem functions and potential restoration endpoints are evaluated (Borde et al. 2014). A general procedure for establishment of objectives during the planning process is described by Thorn (2000):

- Establish a specific target state for the system after a defined period of time as defined by the goal.

- Predict potential alternative states for the system while it progresses toward the target state.

- Develop procedures to follow if the system is in these alternative states.

\subsubsection{Evaluating performance success}

The most developed literature regarding performance success of restoration derives from papers addressing mitigation for impacts to aquatic ecosystems. This literature shows that it is very common for aquatic ecosystem restoration projects not to meet their goals due to poor performance (Thom 2000). The development of science-based theory that would allow for establishing guidance for achieving restoration goals is very limited since most projects are developed for regulatory compliance rather than expanding scientific knowledge (Weinstein et al. 2001) and therefore may lack control plots or alternative restoration treatments. Successfully achieving salt marsh restoration objectives depends on suitable site selection, effective planning and design, the ability to implement restoration action as designed, and long-term monitoring, evaluation, and adaptive management (Teal and Weinstein 2002). General goals related to small-scale restoration experiments and case studies conducted in the past typically include restoring ecosystem structure. If restoration goals are focused on species habitat, carrying capacity of the relevant species must also be known to quantify the success of the restoration (Elliott et al. 2007).

For previous projects, evaluating marsh restoration success has focused on comparison to reference sites, and the degree of success typically depends on project specific goals. Reference sites are located near the restoration project and could be defined in the context of this document as healthy salt marshes that represent the target condition for restoration (Anisfeld 2012). Physical, chemical, and/or biological factors that may be impacting a marsh must be corrected to achieve the desired ecological function or structure (Hackney 2000). Restoration goals have a higher probability of 
being achieved when performance criteria, also known as success criteria, are dependent on restoring processes and functions (Hackney 2000).

Performance criteria is defined in the literature as a quantitative way of determining salt marsh restoration success, which could be classified as compliance success, functional success, and landscape success (Kentula 2000). Compliance success is determined by evaluating compliance with the terms of an agreement (Kentula 2000). Functional success is determined by evaluating whether the ecological functions of the system have been restored (Kentula 2000). Landscape success is a measure of how restoration has contributed to maintaining or improving the ecological integrity of a region, or landscape and achievement of goals such as maintaining the current pattern of biodiversity or restoring a specific pattern that existed in the past (Kentula 2000). Compliance and functional successes are based on the individual project whereas landscape success is based on a larger scale.

Both quantitative and qualitative success criteria are needed to assess ecological success of marsh restoration projects based on reference sites. Short et al. (2000) argue that arbitrary success criteria or those based on a single reference site or species are not appropriate and more replicates would be required within the reference site to obtain data that will best reflect the variability of the site. Ecosystem structure and function are indicators of restoration success. Kentula (2000) stated that quantitative criteria commonly include vegetation measurements (e.g., vegetation cover and production) whereas soils, fauna, and hydrologic measurements are less common. Success indicators for coastal wetland restoration should consider all three basic wetland attributes (water, soil, and organisms) as well as all three levels of scale (ecosystem, landscape, and regional) (Zhao et al. 2008).

\subsubsection{Design guidance}

General design guidance for maintenance of ecological function of salt marshes affected by sea level rise has not been published in the literature. Though there is a rich literature of salt marsh restoration in former wetlands that have been previously converted and are being re-established, most of those methods are not appropriate in areas with existing functional, if degraded, marsh. A thorough understanding of wetland function at local, landscape, and regional levels is needed to design successful projects that 
minimize the temporary impacts to the existing marsh while increasing the long-term viability and function of the marsh.

The design approach for restoration of function to various existing marsh sites (e.g., Narrow River, RI; Seal Beach, CA) affected by sea level rise has been documented and could be used as a basis for future development of design guidance (US FWS 2014a,b; Teal and Weishar 2005; Wigand et al. 2015). For example, the concept of ecological engineering or self-design was used in Delaware Bay for design and restoration of a salt marsh. Ecological engineering sets the stage to allow natural ecosystem function to perform the design and construction in ecosystem restoration (Teal and Weishar 2005). In this case study, the major drainage systems were designed and constructed, and then the drainage patterns were allowed to develop naturally, resulting in natural re-establishment of vegetation and improved natural processes. General findings and approaches encountered in the literature can contribute to improved project design.

Given that there is little published guidance specific for designs of restoration in existing marshes that are degraded from sea level rise, design criteria from more general salt marsh restoration in former marsh areas might provide some insight to potential ways forward. Kentula (2000) describes an approach that frames the study in the context of a model of expected system response by providing a mechanism for explicitly evaluating assumptions on how the system operates and for recognizing knowledge gaps. Simplistic designs and compliance criteria are being replaced by technically sophisticated projects and design goals that incorporate adaptive management for success (Hackney 2000). A well-designed restoration plan incorporates uncertainty and informs stakeholders and managers of projected issues and costs, alternative restoration pathways, proposed endpoints, and informs adaptive management (Hackney 2000). Given the uncertainties associated both with future sea level rise and the marsh response to the management measures available to maintain ecological functions in degraded marshes, designing with adaptive management and uncertainty is an appropriate consideration.

\subsection{Evaluate, monitor, and adaptively manage the response of salt marshes to restoration}

Assessing the response of salt marshes to restoration activities often relies on comparing metrics between a restored marsh (pre- and post- 
restoration) and a reference marsh. Ecological and engineering metrics found in the literature to assess restoration success, monitoring, and adaptive management are briefly summarized below. Many of the metrics described in this section may also be used for initial assessment of degraded marshes as well as in adaptive management of marshes after monitoring identifies that restoration trajectories are not as anticipated. As such, they may also be described in those sections of the report.

\subsubsection{Ecological metrics}

Restoration activities are frequently evaluated by monitoring the response of salt marshes using key ecological indicators. Many ecological indicators chosen for assessment are related to salt marsh functions (Adam 2009). However, the diversity of metrics chosen to assess marsh functions following restoration demonstrates the lack of consistent salt marsh restoration evaluation in the literature (Neckles et al. 2002).

In most cases, metrics associated with vegetation were chosen, followed by animal species composition (Kentula 2000). Vegetation measurements included primary productivity (Barber 2014; Short et al. 2000), plant height, stem density (Konisky 2006; Neckles et al. 2002), percent cover, species composition (Eertman et al. 2002; Hinkle and Mitsch 2005; Weinstein et al. 2001; Wigand et al. 2015; Zhao et al. 2016), soil seed bank, and leaf area index developed specifically for identifying stressed vegetation (Zhao et al. 2016). Weinstein et al. (2001) also evaluated algae production. Animal species composition metrics were related mainly to density and richness of birds (Wigand et al. 2015), fish (Weinstein et al. 2001; Zhao et al. 2016), benthic invertebrates (Eertman et al. 2002), and nekton (Konisky et al. 2006; Weinstein et al. 2001; Wigand et al. 2015; Zhao et al. 2016). The only soil metric routinely measured was soil salinity (Konisky et al. 2006; Neckles et al. 2002; Wigand et al. 2015; Zhao et al. 2016). Other key soil indicators, such as organic matter content and nutrients, were assessed less often or not at all (Kentula 2000). An innovative way of assessing ecological function is through evaluation of bacterial activity to transform available forms of organic matter for secondary consumers (Borde et al. 2014). The bacterial growth efficiency (BGE) is an indicator of ecosystem function, and BGE tends to be lower in restored marshes as compared to natural marshes (Borde et al. 2014). 


\subsubsection{Geomorphic and physical processes metrics}

Geomorphic and physical process metrics typically used to evaluate restoration benefits are driven by hydrologic and geomorphologic parameters, water and sediment characterization, physical processes, tidal variables, and landscape parameters. Hydrology is fundamental for control of salt marsh structure and function (Mitsch and Gosselink 2000). Hydrologic metrics such as the determination of the hydroperiod could be required for permitting purposes (Weinstein et al. 2001). Despite permitting requirements, monitoring for hydrologic metrics may be limited. Data obtained from 36 projects in the Gulf of Maine indicated that hydrology metrics were measured only for $42 \%$ of the projects (Konisky et al. 2006).

Marsh water levels, hydroperiod, tidal range, and marsh surface elevation have been used to understand tidal exchange, marsh flooding, and to determine feasibility of structures built near the marsh (Neckles et al. 2002; Borde et al. 2014; Buchsbaum and Wigand 2012). Tidal circulation data such as tidal range and velocity are used to inform deposition, bar formation, and tidal exchange breadth (Haltiner et al. 1997). Soil organic content, accretion rate, and sediment elevation have been used to understand processes controlling vertical marsh growth after hydrologic restoration (Neckles et al. 2002; Buchsbaum and Wigand 2012). Geomorphic evolution is assessed through metrics associated with tidal characteristics, sediment supply, marsh plain elevation, and channel characteristics since these parameters affect dynamic processes (i.e., erosion, deposition, sedimentation, tidal influence) and response of the system (Haltiner et al. 1997; Eertman et al. 2002). Innovative ways of evaluating wetland restoration include remote sensing, GIS, and global position system (GPS), which have been used to investigate dynamic changes of wetlands in a few studies (Zhao et al. 2016; Feagin and Wu 2006). Weinstein et al. (2001) determined geomorphological features through false color infrared digital orthophotography and GIS analysis for Delaware Bay.

Parameters associated with water chemistry such as salinity, chlorophyll a, and inorganic nitrogen are often measured to indicate water quality, tidal inundation and/or marine inputs (Armitage et al. 2014). Porewater sulfide concentration, $\mathrm{pH}$, redox potential, and nutrients are measured as these may affect restoration goals; for example, redox potential and porewater sulfide concentrations may affect marsh maintenance processes 
(Buchsbaum and Wigand 2012; Neckles et al. 2002). Groundwater conditions are not typically considered; however, these control soil salinity and control the hydrologic regime experienced by plant roots (Haltiner et al. 1997).

Soil accumulation rates, when evaluated, are measured using feldspar marker horizons, radiometric techniques, or sediment erosion tables (SETs). Feldspar marker horizons evaluate short-term vertical accretion rates on the order of 1 to $2 \mathrm{yr}$ (Roman et al. 1997). Radiometric techniques estimate soil accumulation rates over longer time periods using radioisotopes such as ${ }^{137 \mathrm{Cs}}$ (30-50 years) or ${ }^{210} \mathrm{~Pb}$ (50-100 years; Donnelly and Bertness [2001]; Orson et al. [1998]; Roman et al. [1997]). SETs are used to assess elevation change, including soil accretion (Barber 2014; Cahoon et al. 1995; Neckles et al. 2002; Wigand et al. 2015).

Geomorphic and physical metrics chosen for the Narrow River, RI, project included hydrology, sediment accretion, soil characterization, open water extent, and elevation surveys (Wigand et al. 2015). Qualitative and quantitative metrics used under the Restore Act (Gulf Coast Ecosystem Restoration Council, Restore, n.d.) to evaluate the ecological benefits and outcomes of multiple restoration projects in the Gulf Coast include water depth, salinity, flow patterns, marsh acreage restored/conserved, potential for long-term management, volume of sediment to be used beneficially, quality and quantity of storm surge protection, and sediment and nutrient attenuation (Gulf Coast Ecosystem Restoration Council, Restore, n.d.). Land-to-water ratios and erosion rates have been used to determine if Coastal Wetland Planning, Protection, and Restoration Act (CWPPRA) projects have met their goals (Borde et al. 2014). The monitoring SET-MH network discussed in the engineering assessment section is used for conducting a quantitative comparative assessment of wetland response to current sea level rise upon restoration implementation (Cahoon 2006).

Several studies linked geomorphic and physical process metrics directly with ecological parameters or processes. Hood (2002) linked hydraulic geometry metrics to ecological processes; Williams and Zedler (1999) linked channel morphology to fish assemblage; Bayard and Elphick (2011) linked tide height and flooding frequency to nest fate in a marsh system; Hinkle and Mitsch (2015) linked high vegetation coverage to stable tidal hydrology. 


\subsubsection{Monitoring}

Adequate assessment of coastal restoration requires a long-term systematic approach to monitoring and a coordinated experimental research program to explain patterns that emerge from the data (Calloway et al. 2001). In the same manner, data and lessons learned from long-term monitoring programs can be used to guide future research and restoration efforts (Barber 2014; Calloway et al. 2001). Some of the most effective restoration programs integrate pilot studies or experimental designs into their monitoring programs prior to restoration actions (Borde et al. 2014).

Success of a restoration monitoring program is mainly based on its design, including monitoring approach, parameters, duration, and selection of appropriate reference sites (Adam 2009; Lewis 2000; Weinstein et al. 2001; Armitage et al. 2014), which requires an understanding of the ecosystem and landscape function and factors causing variation and affecting their response (Wigand et al. 2015). A reference marsh should not be actively managed or altered and should be similar to restoration sites in terms of size, geomorphology, potential tidal range, landscape position, adjacent land use, water quality, and other characteristics (Neckles et al. 2002; Armitage et al. 2014; Adam 2009). Finding adequate reference areas has become more challenging because many projects are adjacent to each other; this potentially results in cumulative, indirect influences on landscape level processes that are difficult to assess and consider for individual project effectiveness. In Louisiana and California, a network of reference sites was established to allow both project-specific and landscape evaluations and comparisons (Borde et al. 2014; Calloway et al. 2007; Glick et al. 2013; Steyer et al. 2002). Elliot et al. (2007) proposed that if marsh restoration does not result in a return to reference conditions, ecosystems can be evaluated over space or time in terms of their functional characteristics or their ability to provide valued ecosystem services, through monitoring programs.

Monitoring is critical for project restoration success, evaluation, and adaptive management (DiGennaro et al. 2012; Nicholls 2003; Palermo and Dardeau 1994; Teal and Weishar 2005) and may be performed for permit compliance and to expand science knowledge by evaluating key ecosystem parameters and processes relevant to restoration objectives (Wigand et al. 2015; Borde et al. 2014; Adam 2009; Simenstad et al. 2006). Information obtained from monitoring programs can be utilized by planners and managers to determine if a restoration project is progressing 
towards the goal (Redmond 2000), to assure that project goals are met, or to employ adaptive management if needed (Borde et al. 2014; Adam 2009; Thom 2000; WRDA 2007).

Project goals must be clearly stated to be able to develop performance criteria to be used for evaluating monitoring parameters (Haltiner et al. 1997; Elliot et al. 2007; Thom and Wellman 1996; Weinstein et al. 2001; WRDA 2007). Performance criteria are defined as quantitative measurements used to determine salt marsh restoration success. Development of performance criteria involves linking the criteria to the project goals and metrics and specifying criteria boundaries (Thom 2000; WRDA 2007). U.S. Fish and Wildlife Service (USFWS) and U.S. Geological Survey (USGS) have identified metrics to monitor salt marsh integrity on National Wildlife Refuges, which are practical to also implement on a regional scale (Neckles et al. 2013). These metrics have also been adopted by the Department of Interior to implement on projects funded through the Disaster Relief Recovery Act of 2013 (US DOI 2015). For example, restoration projects funded through the Hurricane Sandy Mitigation and Resilience Program are required to include these metrics to monitor salt marsh integrity. When restoration projects have multiple objectives, the assessment of the monitoring parameters will require different sampling designs, both spatially and temporally. However, if resources are limited, including all components within a single sampling design may result in none being measured adequately (Adam 2009). Many monitoring programs fail because the selected performance criteria overburden resources or lack acceptable linkages to the project goals (Thayer and Kentula 2005).

Section 2039 of WRDA (2007) requires a plan for monitoring the success of ecosystem restoration projects, which should include a description of the monitoring program, the criteria for success, cost estimates, duration, and the party responsible for conducting monitoring. The monitoring program scope and duration should include the minimum monitoring actions required to evaluate success (Thom 2000; WRDA 2007). The law allows for but does not require a 10-year, cost-shared monitoring plan, which will be considered a shared project cost funded under construction. Reported monitoring costs range from $3 \%$ to $62 \%$ with an average of $13 \%$ of the total cost of restoration projects (Thom 2000). Costs for monitoring beyond $10 \mathrm{yr}$ will be a non-federal responsibility. Some restoration projects may require monitoring beyond $10 \mathrm{yr}$; for example, a restoration 
project in the Netherlands demonstrated that even though ecological restoration started rapidly, ecological changes in the marsh were still occurring after $10 \mathrm{yr}$ of project implementation (Eertman et al. 2002).

Stakeholders recommend implementation of a before-after, controlimpact (BACI) sampling design when possible to assess the success of restoration actions (Wigand et al. 2015). Monitoring should be conducted before and after restoration, at a reference site and impacted sites, as prescribed by the BACI design. When reference sites are not available and the BACI design is not feasible, before-and-after assessments at the impacted sites should be conducted (Wigand et al. 2015). Kentula (2000) indicated that success of marsh restoration should be tested at a larger scale (e.g., landscape, landscape unit, and region). Long-term monitoring is ultimately used to assess restoration success. Long-term monitoring and assessment methods at multiple size scales should be developed to monitor restored coastal wetlands dynamically and continuously from prerestoration through long term (Zhao et al. 2016). Pre-restoration monitoring is conducted to determine the existing marsh functions and to provide information on potential restoration endpoints and aid with the development of project goals (Borde et al. 2014). The lack of prerestoration data, which is very common for restoration projects, complicates data evaluation and interpretation (Eertman et al. 2002). Standard monitoring protocols are essential for cases for coordinated restoration programs that involve multiple projects. Seal Beach, CA, and Narrow River, RI, have developed long-term monitoring programs that assess multiple ecological and engineering metrics; both projects are currently being monitored (US FWS 2014a,b).

\subsubsection{Adaptive management}

Adaptive management strategies along with plausible sea level rise rates and scientific principles and models are commonly recommended to reduce uncertainty associated with projects that employ techniques for restoration of salt marshes affected by relative sea level rise (Glick et al. 2013; Borde et al. 2014; Thom 1997; USACE 2014; Day et al. 2007; Nicholls 2003; Redmond 2000; Kentula 2000; CWPPRA 2015; Willows and Connell 2003; NRC 1995; Adam 2009). Adaptive management consists of evaluating restoration techniques and identifying corrective/remedial actions to improve project design and performance when an established goal is not progressing or being met (Kentula 2000; Borde et al. 2014; Hackney 2000). Section 2039 of WRDA (2007) requires 
the development of an adaptive management plan for all ecosystem restoration projects.

The literature suggests that adaptive management plans should be developed in the planning phase of a project (Borde et al. 2014) by managers, stakeholders, engineers, and scientists (Ewel 2001; Tol et al. 2008; Zhao et al. 2016). An adaptive management framework should combine well-defined goals with targets for specific structural and functional components (e.g., vegetation and hydrology), a schedule for management and restoration activities, sound models to predict responses of the system, active data collection and monitoring based on established criteria, interim criteria with triggers, and a commitment to adjust the conceptual models, monitoring plan, and even project goals if interim criteria are not met (Teal and Weishar 2005; Ewel 2001; Thayer and Kentula 2005; Thom 2000; Buchsbaum and Wigand 2012; Zhao et al. 2016). Conceptual models are essential to successful adaptive management by providing valuable insight for ecosystem restoration planning; however, more quantitative approaches for making predictions are needed (Thom 2000; DiGennaro et al. 2012; Healey et al. 2007; NRC 2010; Hackney 2000; Fischenich 2008).

Information and data collected from monitoring efforts are essential to evaluate project progress and goals, and make adjustments if necessary (US FWS 2014a; Borde et al. 2014; Thom 1997; Warren et al. 2002; Tol et al. 2008; Thom 2000; Buchsbaum and Wigand 2012; Zedler and Kercher 2005). The three main actions associated with adaptive management adjustments include doing nothing and accepting the current outcome, doing something to affect an outcome closer to the original intent, and changing the project goal to include multiple goals (Thom 2000). The adaptive management framework enables learning from the results but needs to be applied as it was designed in all its scientific rigor; otherwise, the project will fail (Simenstad et al. 2006).

Adaptive management has been recommended for a large number of restoration projects associated with sea level rise (e.g.. Narrow River, RI; San Francisco Bay marshes; Jamaica Bay; Mississippi River Delta; Seal Beach, CA; various projects under the RESTORE Act) and as a part of general approaches for monitoring (US FWS 2014a; Callaway et al. 2007; Ayyub and Kearney 2012; Boere and Taylor 2004; NYC DEP 2007; NRC 1995; La Peyre et al. 2009; Lewis 2000; Neckles et al. 2002; Verhoeven 
2006; US FWS 2014c; USACE 2014). Few projects (e.g., tidal marsh restoration in Louisiana; Delaware Bay, Sacramento - San Joaquin Delta in California) documented the steps undertaken for adaptive management (Borde et al. 2014; Hinkle and Mitsch 2005; Weinstein et al. 2001; DiGennaro et al. 2012). The adaptive management approach developed for these projects generally consisted of assessing the problem, setting up project restoration goals, developing conceptual models, and employing a decision framework (evaluating restoration actions through research, pilot-scale and/or full-scale studies, adapting and re-assessing if necessary). Wigand et al. (2015) modified this approach to identify climate-related vulnerabilities and propose climate change adaptation actions and monitoring schemes. Weinstein et al. (2011) incorporated an additional component to adaptive management for Delaware Bay called restoration management. This process attempted to address potential problems that might interfere with restoration success before involving a formal trigger associated with adaptive management. Long-term followup through adaptive management for a decade was recommended for Delaware Bay (Teal and Weinstein 2002). A decision-support tool consisting of a decision tree, valuable for restoration planning and adaptive management, was developed for evaluating restoration actions for the Sacramento - San Joaquin Delta in California (DiGennaro et al. 2012). An integrated modeling framework for salt marshes was developed for adaptive management and decision analysis for Florida Coastal Military Installations and incorporates multiscale climate, land use, and ecosystem information (Convertino et al. 2011). 


\section{Discussion}

Salt marshes are productive coastal habitats that not only support rare species but also provide society with various ecosystem services, from flood and storm surge protection to fisheries production (Gedan et al. 2009; Zedler and Kercher 2005; Fagherazzi et al. 2013). While typically able to biogenically maintain themselves under low rates of sea level rise and sufficient sediment supply, many tidal marshes are now experiencing relative sea level rise that causes inundation of the marsh plain and a cascade of ecological impacts (Ferland 1990; Pennings and Bertness 2001; Orr et al. 2003). Factors contributing to relative sea level rise include climate-change induced eustatic sea level rise, tectonic activity, subsidence, interruption of sediment supply, local factors affecting sea temperature, shifts in rainfall patterns, and vertical land movements (Barber 2014; Belperio 1993; Cazenave and Nerem 2004; Engelhart et al. 2009; Ericson et al. 2006; Kirwan et al. 2010; Mote et al. 2008). This relative sea level increase destabilizes marshes by undermining ecogeomorphic feedbacks related to vegetation growth and vitality, erosion and sedimentation that normally preserve marsh elevations within the intertidal zone required by the prevalent marsh species (Ferland 1990; Pennings and Bertness 2001; Orr et al. 2003).

Because of the importance of marshes, many agencies and land managers are attempting to document the decline of the marshes and take steps to maintain them. These efforts borrow from ecological restoration techniques, but the contexts of the efforts can be quite different. Whereas up till the present, most coastal wetland restoration was typically done in areas that were historically wetlands but have been degraded by hydrologic isolation via dikes (e.g., salt ponds, hay fields) (Orr et al. 2003); maintenance or restoration efforts in salt marshes compromised by relative sea level rise requires management activities in areas that are still functioning on some level as coastal wetlands. USACE provided guidance for understanding the direct, indirect, physical, and ecological effects of projected sea level change on USACE projects and considerations for adapting to those effects (USACE 2014). USACE updated its Climate Change Adaptation Plan in 2015, advising planners on addressing climate change related risks to USACE missions and operations (USACE 2015). While this revised plan offered insights to physical and ecological effects of sea level rise, it did not specifically address restoration in light of these effects or maintenance of existing ecosystems. Nicholls and Lowe (2006) 
have also asserted that a combination of mitigation and adaptation may provide a more robust response to climate change. As there is a potential for action to further damage salt marsh ecosystems, it is imperative that the marsh condition be accurately assessed and the source of marsh degradation be well understood for management actions to be effective.

This report identified three broad approaches to assess the condition of salt marshes: computer-based assessments, field-based ecological assessments, and geomorphologic and physical processes assessments. Computer-based assessments ranging from aerial photography to ecosystem process modeling are valuable for identifying vulnerable, impacted, or threatened salt marshes when the required data for conducting the models are available (Fagherazzi et al. 2012; Kirwan and Murray 2007; Martin et al. 2002). Combination of multiple computerbased methods is becoming more common and not only allows for data corroboration but also for detailed comparisons with reference sites (Heberger et al. 2009). In the available literature, vegetation assessments are more common than soil, hydrology, geomorphology, elevation, and physical processes evaluations. Evaluation of marsh conditions using soil metrics is restricted by lack of consistency in metrics used (Wigand et al. 2015; US FWS 2014b; Twohig and Stolt 2011). Geomorphology and physical processes assessments found in the literature are very broad and applied inconsistently across projects. No projects assessed all of the metrics identified through this effort, and few addressed multiple types of metrics. Reliance on vegetation community and cover metrics to document marsh condition can hinder effective management because the vegetation only responds once the environmental stressors are fairly advanced. Further, plants can die back for a number of reasons, so a decrease in cover does not necessarily indicate the particular stressor that needs to be addressed by the management actions. Few early indicator metrics have been proposed in the literature, and those that are being considered have only been tested in limited geographic regions: total suspended solids in neap and ebb flow, soil strength and morphology, stable plant fragment by volume, loading response, and penetration depth (Ganju et al. 2015; Twohig and Stolt 2011; Wigand et al. 2015). To have broader applications, calibrations of the metrics would need to be done using a range of environmental factors and geographic regions.

Assessing multiple metrics provides a better understanding of the factors contributing to marsh conditions and therefore processes that require 
adjustment in restoration. Understanding these factors is important to be able to understand the ecosystem response and to develop appropriate restoration strategies, modeling, adaptive management, and monitoring. The main challenge for salt marsh restoration is determining the contributing factors and deciding the best restoration action to manage the impacts and reduce or reverse the loss (NPS 2004). All possible factors must be considered during assessment since multiple factors may have compounded or synergistic effects (O’Neill 2015; Hartig et al. 2002; Hine 2015). Restoration plans are commonly implemented on a project-specific basis; however, it is often larger system processes that are causing marsh degradation, and therefore a synergistic and integrated strategic approach with a regional/landscape basis considering both climate and non-climate factors is needed for success of restoration projects (Tol et al. 2008; Borde et al. 2014).

This report identified multiple innovative restoration or management techniques identified in the literature, each addressing a specific stressor. Hydrologic stress occurs when tidal exchange is limited or impounding because tidal creeks are insufficient to carry away pooled water. While levee or dike breaching is generally used to restore tidal exchange within a marsh that has been previously isolated (Borde et al. 2004; Simenstad et al. 2006), there are also cases in which it benefits existing marshes (Konisky et al. 2006; Day et al. 2016). This facilitates the exchange of nutrients, import of sediments, and reestablishment of appropriate salinity gradients.

The creation of runnels or tidal creeks is also intended to facilitate the exchange of tidal waters and drainage of water from back portions of the marsh (Dale 2007; Koo et al. 2011; Reed et al. 1999; Teal and Weishar 2005; Weishar et al. 2005). Both of these techniques have been demonstrated to have positive vegetation responses in several studies.

When a lack of sediment source is identified as the primary stressor, management options can provide sediment by indirect methods, such as removing inland dams to reconnect a marsh with its natural sediment supply, or by more direct methods, such as importing sediment into the system. While connecting marshes to their natural sediment sources is preferable from a sustainability standpoint and is the preferred method 
being actively considered in the Pacific Northwest ${ }^{1}$, it is not always possible in urbanized areas where dams are semi-permanent landscape features with water supply, hydropower, flood protection, or recreational purposes to consider. In addition, marshes are sometimes in more immediate need of sediment to prevent imminent loss than restoration of sediment processes would facilitate. In these cases, direct application of sediment via thin layer placement has been used to raise the elevation of the marsh plain to levels that support marsh vegetation.

Thin layer placement involves the application of dredged material or other sediments in either pools developing in a marsh or across an entire marsh to raise the elevation to one suitable for marsh vegetation (Palermo and Dardeau 1994). While there are temporary impacts associated with placement on existing marsh plain, some studies have shown long-term beneficial responses. In addition, several new pilot studies in different parts of the United States are being extensively monitored and should provide more insight into the benefits or risks associated with thin layer placement (US FWS 2014a,b).

Nearshore placement also addresses marshes with decreased sediment supply. This technique places dredged material close to a marsh in the subtidal zone and relies on currents and geomorphic processes to carry it up onto the marsh plain (Lowe and Bourgeois 2015). While this would reduce the temporary impacts associated with thin layer placement, there are no data yet available to determine its effectiveness in marsh habitats. New studies being considered in California may shed light on this in future years.

Sea level rise and increased storm intensity can also lead to erosion of the marsh edge. Restoration techniques addressing this stressor include living shoreline applications (oyster shells, vegetation, or coconut fiber (coir) logs at the marsh edge); marsh sediment fences comprising recycled Christmas trees or other woody vegetation; and marsh terracing, which creates islands of emergent marsh from subtidal sediments in front of the marsh plain, which help diffuse wave energy before it reaches the marsh plain (Armitage et al. 2014; Feagin and Wu 2006; Rozas and Minello 2001; Rozas et al. 2005). All of these techniques have been demonstrated to have some success.

1 Jay Krienz and Tish Conway-Cranos, Washington Department of Fish and Wildlife, personal communication, July 2016. 
Many of these restoration techniques are relatively new. While there are indications that they can be successful in some cases, more extensive monitoring and data sets would allow a clearer view of what circumstances they are best suited for and how effectiveness might vary among geographic regions where soils, tidal range, and dominant species might influence outcomes. Tying restoration techniques to stressors and specific assessment metrics is a challenge that will need to be addressed before detailed national guidelines can be developed.

Restoration challenges are infrequently documented in the literature. However, they provide valuable lessons learned to inform future restoration efforts. For example, potential formation of iron sulfides may prevent or delay the establishment of vegetation at some thin layer placement pilot studies, but this is not documented in the literature ${ }^{1}$. Understanding the soil chemistry, chemistry of the dredge material, and oxidation potential once the material is placed on the marsh could help elucidate how these outcomes might be prevented.

Restoration techniques need a science-engineering-based approach for design, management, implementation, monitoring, and adaptive management. Modeling approaches for evaluation of restoration techniques on salt marshes affected by sea level are scarce; hence, there is a significant need for development of models in this area. Utilizing existing models that evaluate sea level rise on salt marshes could provide a basis for evaluating restoration actions and potential effectiveness before implementation (e.g., SLAMM). Also, models that simulate processes such as compaction and consolidation are being developed for thin layer placement techniques. Models developed for other purposes for evaluation of restoration techniques or sea level rise could also be used as a basis for salt marshes. Much of this work, as well as applications of new restoration techniques, is currently underway. Results are not yet available in the literature but will be informing the practice over the next several years.

Beyond addressing applicable restoration techniques, adequate assessment of coastal restoration requires a long-term, systematic approach to monitoring and a coordinated experimental research program to explain patterns that emerge from the data (Calloway et al. 2001). In the same manner, data and lessons learned from long-term monitoring programs can

\footnotetext{
1 Jennifer White, U.S. Fish and Wildlife Service, personal communication, August 2016.
} 
be used to guide future research and restoration efforts (Barber 2014; Calloway et al. 2001). Some of the most effective restoration programs integrate pilot studies or experimental designs into their monitoring programs prior to restoration actions (Borde et al. 2014). Multiple metrics for assessing salt marshes after restoration have been applied. Moreover, most of the assessment metrics used for determining marsh loss and degradation could also be applied for assessment after restoration. Certain metrics, such as tidal exchange and elevation, respond quickly to restoration and could potentially provide an early indicator of the likelihood of project success (Buchsbaum and Wigand 2012). Other potential early indicators that require further investigation include soils characteristics and microbial communities (Berkowitz et al. 2017). Conceptual models can provide a strong foundation for the development of metrics, monitoring plans, and performance measures (DiGennaro et al. 2012).

Now standard practice for USACE projects, adaptive management strategies are used for restoration projects associated with sea level rise to reduce uncertainty associated with these projects (WRDA 2007). Adaptive management framework combines well-defined goals with targets for specific structural and functional components (e.g., vegetation and hydrology), a schedule for management and restoration activities, sound models to predict system responses, active data collection and monitoring based on established criteria, interim criteria with triggers, and a commitment to adjust the conceptual models, monitoring plan, and even project goals if interim criteria are not met (Teal and Weishar 2005; Ewel 2001; Thom 2000; Buchsbaum and Wigand 2012; Zhao et al. 2016).

Finally, because restoration of tidal marshes suffering effects of sea level rise are occurring within existing ecosystems, it is vital that metrics are tied to determining stressors, restoration efforts tied to addressing those stressors, and that unforeseen consequences of restoration measures do not make matters worse. Metrics that allow early indications that marshes are actively degrading at rates above those normally found in dynamic but fundamentally stable systems would allow for earlier and potentially less dramatic intervention and are a major research need as these efforts move forward. 


\section{Summary}

This special report summarizes much of the information available on the effects of sea level rise on marshes, the metrics available to assess marshes and the response to restoration, and the various restoration techniques available. It has also highlighted data gaps that may require additional research. Using a broad range of metrics provides more information for determining the particular stressors impacting a marsh, which is key to selection of appropriate management and restoration strategies. In addition, using metrics that have the ability to detect stress before major ecological and physical changes in the marsh have occurred will reduce the severity of the management actions. Marsh assessment leads to identification of primary stressors impacting a particular marsh and selection of relevant restoration techniques. There is much opportunity to expand and refine assessment metrics, especially regarding early indicators that might allow intervention in tidal salt marshes before ecosystem structures and processes are significantly undermined. Preliminary measures used in the literature have been identified, but further work is necessary to determine whether these measures are applicable outside the geographical range of their initial development and calibrating them to different areas or species so that these measures are applicable across the nation. This report also addressed available models considering marsh responses to sea level rise, but there is significantly more work to be done in this rapidly expanding area. Restoration practitioners are not always familiar with the various models' capabilities, and addressing those more thoroughly could benefit both the identification of marshes at risk and analysis of restoration alternatives. Finally, soil and dredge material chemistry may interact in adverse ways after placement, and understanding these potential chemical interactions is critical to restoration success. Research detailing the conditions that could impede restoration success is an important avenue of futures research. Addressing some of these data gaps will be the focus of the work unit in upcoming years to better develop regionally and nationally applicable restoration guidelines. 


\section{References}

Adam, P. 2009. "Salt Marsh Restoration." In Coastal Wetlands: An Integrated Ecosystem Approach, edited by G. Perillo, E. Wolanski, D. Cahoon, and M. Brinson, 737-761. New York: Elsevier.

Allen, J. R. L. 2000. "Morphodynamics of Holocene Salt Marshes: A Review Sketch from the Atlantic and Southern North Sea Coasts of Europe." Quaternary Science Reviews 19: 1155-1231.

Anisfeld, S. C. 2012. "Biogeochemical Responses to Tidal Restoration." In Tidal Marsh Restoration: A Synthesis of Science and Management, edited by C. T. Roman and D. M. Burdick. Washington, DC: Island Press.

Arkema, K. K., G. Guannel, G. Verutes, S. A. Wood, A. Guerry, M. Ruckelshaus, P. Kareiva, M. Lacayo, and J. M. Silver. 2013. "Coastal Habitats Shield People and Property from Sea-Level Rise and Storms." Nature Climate Change 3: 913-919.

Armitage, A. R., C. Ho, E. N. Madrid, M. T. Bell, and A. Quigg. 2014. "The Influence of Habitat Construction Technique on the Ecological Characteristics of a Restored Brackish Marsh.” Ecological Engineering 62: 33-42.

Aronson, J., S. Dhillion, and LeFloc'h. 1996. "On the Need to Select an Ecosystem of Reference, However Imperfect: A reply to Pickett and Parker." Restoration Ecology 3(1): 1-3.

Ayyub, B. M., and M. S. Kearney. 2012. Sea Level Rise and Coastal Infrastructure Prediction, Risks, and Solutions. Reston, VA: American Society of Civil Engineers.

Barber, A. 2014. Sediment and Vegetation Monitoring during a Levee Removal Project on the Stillaguamish River Delta at Port Susan Bay, WA. MS thesis, Western Washington University, Bellingham, WA.

Baustian, J. J., and I. A. Mendelssohn. 2015. “Hurricane-Induced Sedimentation Improves Marsh Resilience and Vegetation Vigor under High Rates of Relative Sea Level Rise.” Wetlands 18: 3,377-3,382.

Baustian, J. J., I. A. Mendelssohn, and M. W. Hester. 2012. “Vegetation's Importance in Regulating Surface Elevation in a Coastal Salt Marsh Facing Elevated Rates of Sea Level Rise." Global Change Biology 18: 3,377-3,382.

Bayard, T. S., and C. S. Elphick. 2011. "Planning for Sea-Level Rise: Quantifying Patterns of Saltmarsh Sparrow (Ammodramus caudacutus) Nest Flooding under Current Sea-Level Conditions." The Auk 128: 393-403.

Belperio, A. P. 1993. "Land Subsidence and Sea Level Rise in the Port Adelaide Estuary: Implications for Monitoring the Greenhouse Effect." Australian Journal of Earth Sciences 40(4): 359-368. 
Berkowitz, J., C. VanZomeren, and C. Piercy. 2017. "Marsh Restoration Using Thin Layer Sediment Addition: Intitial Soil Evaluation." Wetland Science and Practice, March 2017.

Blum, L. K. 1993. "Spartina alterniflora Root Dynamics in a Virginia Marsh." Marine Ecology Progress Series 102: 169-178.

Blum, M. D., and H. H. Roberts. 2009. "Drowning of the Mississippi Delta Due to Insufficient Sediment Supply and Global Sea-Level Rise.” Nature Geoscience 2: 488-491

Boere, G. C., and D. Taylor. 2004. "Global and Regional Governmental Policy and Treaties as Tools towards the Mitigation of the Effect of Climate Change on Waterbirds.” Ibis 146: 111-119.

Boesch, D. E., M. N. Josselyn, A. J. Mehta, J. T. Morris, W. K. Nuttle, C. A. Simenstad, and D. J. P. Swift. 1994. "Scientific Assessment of Coastal Wetland Loss, Restoration and Management in Louisiana." Journal of Coastal Research 20: 103.

Borde, A. B., L.K. O’Rourke, R. M. Thom, G. W. Williams, and H. L. Diefenderfer. 2004. National Review of Innovative and Successful Coastal Habitat Restoration. Prepared for National Oceanic and Atmospheric Administration Coastal Services Center. Battelle Memorial Institute, Contract 44188. Sequim, WA.

Boumans, R., and J. W. Day, Jr. 1993. "High Precision Measurements of Sediment Elevation in Shallow Coastal Areas Using a Sedimentation-Erosion Table.“ Estuaries 16: 375-380.

Boumans, R. M. J., J. W. Day, G. P. Kemp, and K. Kilgen. 1997. "The Effect of Intertidal Sediment Fences on Wetland Surface Elevation, Wave Energy and Vegetation Establishment in Two Louisiana Coastal Marshes." Ecological Engineering 9: 37-50.

Bowron, T. M., N. Neatt, D. van Proosdij, and J. Lundholm. 2012. "Salt Marsh Tidal Restoration in Canada's Maritime Provinces." In Tidal Marsh Restoration: A Synthesis of Science and Management, edited by C. T. Roman and D. M. Burdick. Washington, DC: Island Press.

Brawley, H. A., R. S. Warren, and R. A. Askins. 1998. "Bird Use of Restoration and Reference Marshes within the Barn Island Wildlife Management Area, Stonington, Connecticut, USA.” Environmental Management 22: 625-633.

Bridges, T. S., P. W. Wagner, K. A. Burks-Copes, M. E. Bates, Z. A. Collier, C. J. Fischenich, J. Z. Gailani, L. D. Leuck, C. D. Piercy, J. D. Rosati, E. J. Russo, D. J. Shafer, B. C. Suedel, E. A. Vuxton, and T. V. Wamsley. 2015. Use of Natural and Nature-Based Features (NNBF) for Coastal Resilience. ERDC SR-15-1. Vicksburg, MS: U.S. Army Engineer Research and Development Center.

Brinker, D. F., J. M. McCann, B. Williams, and B. D. Watts. 2007. "Colonial-Nesting Seabirds in the Chesapeake Bay Region: Where Have We Been and Where Are We Going?” Waterbirds 30: 93-104. 
Brinson, M. M., R. R. Christian, and L. K. Blum. 1995. "Multiple States in the Sea-Level Rise Induced Transition from Terrestrial Forest to Estuary.” Estuaries 18: 648659.

Bromirski, P. D., A. J. Miller, R. E. Flick, and G. Auad. 2011. "Dynamical Suppression of Sea Level Rise along the Pacific Coast of North America: Indications for Imminent Acceleration.” Journal of Geophysical Research 116: Co7005.

Broome, S. W., and C. B. Craft. 2009. "Tidal Marsh Creation.” In Coastal Wetlands: An Integrated Ecosystem Approach, edited by G. Perillo, E. Wolanski, D. Cahoon, and M. Brinson, 715-736. New York: Elsevier.

Buchanan, M. K., M. Oppenheimer, and R. E. Kopp. 2017. “Amplification of Flood Frequencies with Local Sea Level Rise and Emerging Flood Regimes.” Environ. Res. Lett. 12(6): 1-7.

Buchsbaum, R. N., and C. Wigand. 2012. "Adaptive Management and Monitoring as Fundamental Tools to Effective Salt Marsh Restoration." In Tidal Marsh Restoration: A Synthesis of Science and Management, edited by C. T. Roman and D. M. Burdick. Washington, DC: Island Press.

Burkett, V., and J. Kusler. 200o. "Climate Change: Potential Impacts and Interactions in Wetlands of the United States." Journal of the American Water Resources Association 36: 313-320.

Cahoon, D. 2006. "A Review of Major Storm Impacts on Coastal Wetland Elevations." Estuaries and Coasts 29: 889-898.

Cahoon, D. R., and J. H. Cowan, Jr. 1987. Spray Disposal of Dredged Material in Coastal Louisiana: Habitat Impacts and Regulatory Policy Implications. Louisiana Sea Grant College Program, Louisiana State University, Baton Rouge, LA.

Cahoon, D. R., and R. E. Turner. 1989. "Accretion and Canal Impacts in a Rapidly Subsiding Wetland II: Feldspar Marker Horizon Technique.” Estuaries 12: 260268.

Cahoon, D. R., D. J. Reed, and J. W. Day, Jr. 1995. "Estimating Shallow Subsidence in Microtidal Salt Marshes of the Southeastern United States: Kaye and Barghoon revisited." Marine Geology 128: 1-9.

Cahoon, D. R., J. W. Day, Jr., and D. J. Reed. 1999. "The Influence of Surface and Shallow Subsurface Soil Processes on Wetland Elevation: A Synthesis." Current Topics in Wetland Biogeochemistry 3: 72-88.

Cahoon, D. R., J. C. Lynch, P. F. Hensel, R. Boumans, B. C. Perez, B. Segura, and J. W. Day, Jr. 2002a. "High Precision Measurement of Wetland Sediment Elevation: I. Recent Improvements to the Sedimentation-Erosion Table.” Journal of Sediment Research 72: 730-733.

Cahoon, D. R., J. C. Lynch, B. C. Perez, B. Segura, R. Holland, C. Stelly, G. Stephenson, and P. Hensel. 2002b. "High Precision Measurement of Wetland Sediment Elevation: II. The Rod Surface Elevation Table.” Journal of Sediment Research 72: 734-739. 
Cahoon, D. R., P. F. Hensel, T. Spencer, D. J. Reed, K. L. McKee, and N. Saintilan. 2006. "Coastal Wetland Vulnerability to Relative Sea-Level Rise: Wetland Elevation Trends and Process Controls.” Ecological Studies 190: 271-292.

Cairns, J., Jr., 2000. "Setting Ecological Restoration Goals Technical Feasibility and Scientific Validity.” Ecological Engineering 15: 17-18.

Callaway, J. C., G. Sullivan, J. S. Desmond, G. D. Williams, and J. B. Zedler. 2001. "Assessment and Monitoring." In Handbook for Restoring Tidal Wetlands. Boca Raton, FL: CRC Press LLS.

Callaway, J. C., V. T. Parker, M. C. Vasey, and L. M. Schile. 2007. "Emerging Issues for the Restoration of Tidal Marsh Ecosystems in the Context of Predicted Climate Change." Madroño 54: 234-248.

Cazenave, A., and R. S. Nerem. 2004. "Present-Day Sea Level Change: Observations and Causes." Rev. Geophys. 42(3): RG3001. https://doi.org/10.1029/2003RG000139.

Christiansen, T., P. L. Wiberg, and T. G. Milligan. 1999. "Flow and Sediment Transport on a Tidal Salt Marsh Surface.” Estuarine, Coastal, and Shelf Science 50: 305-331.

Church, J. A., P. U. Clark, A. Cazenave, J. M. Gregory, S. Jevrejeva, A. Levermann, M. A. Merrifield, G. A. Milne, R. S. Nerem, P. D. Nunn, A. J. Payne, W. T. Pfeffer, D. Stammer, and A. S. Unnikrishnan. 2013: "Sea Level Change." In Climate Change 2013: The Physical Science Basis. Contribution of Working Group I to the Fifth Assessment Report of the Intergovernmental Panel on Climate Change, edited by T. F. Stocker, D. Qin, G.-K. Plattner, M. Tignor, S. K. Allen, J. Boschung, A. Nauels, Y. Xia, V. Bex, and P. M. Midgley. United Kingdom and New York: Cambridge University Press.

Clausen, K. K., M. Stjernholm, and P. Clausen. 2013. "Grazing Management Can Counteract the Impacts of Climate Change-Induced Sea Level Rise on Salt Marsh-Dependent Waterbirds.” Journal of Applied Ecology 50: 528-537.

Coastal Conservancy. 2014. Seal Beach National Wildlife Refuge Thin-Layer Salt Marsh Sediment Augmentation Pilot Project. Staff Recommendation, Project No. 14029-01. Vicksburg, MS: U.S. Army Engineer Research and Development Center, Environmental Laboratory.

Coastal Wetlands Planning, Protection, and Restoration Act (CWPPRA). 2015. Partners in Restoration. https://lacoast.gov/products/PIR_final_combined.pdf

Collins, J., and D. Ball. 2015. "Science Foundation Chapter 4: Connections to the Watersheds: The Estuarine-Terrestrial Transition Zone." Baylands Ecosystem Habitat Goals Science Update. https://baylandsgoals.org/wpcontent/uploads/2015/10/BEHGU_SFC4.pdf.

Convertino, M., G. A. Kiker, M. L. Chu-Agor, R. Muñoz-Carpena, C. J. Martinez, M. Aiello-Lammens, H. R. Akçakaya, R. A. Fischer, and I. Linkov. 2011. Chapter 23: "Integrated Modeling to Mitigate Climate Change Risk Due to Sea Level Rise, Imperiled Shorebirds on Florida Coastal Military Installations.” NATO Science for Peace and Security Series C: Environmental Security. https://link.springer.com/content/pdf/10.1007\%2F978-94-007-1770-1_23.pdf. 
Cornu, C. E., and S. Sadro. 2002. "Physical and Functional Responses to Experimental Marsh Surface Elevation Manipulation in Coos Bay's South Slough.” Restoration Ecology 10: 474-486.

Coverdale, T. C., C. P. Brisson, E. W. Young, S. F. Yin, J. P. Donnelly, and M. D. Bertness. 2014. "Indirect Human Impacts Reverse Centuries of Carbon Sequestration and Salt Marsh Accretion.” PLOS ONE 9: e93296.

Craft, C. 2007. "Freshwater Input Structures Soil Properties, Vertical Accretion, and Nutrient Accumulation of Georgia and U.S. Tidal Marshes." Limnology and Oceanography 52: 1,220-1,230.

Craft, C. B., E. D. Seneca, and S. W. Broome. 1993. "Vertical Accretion in Microtidal Regularly and Irregularly Flooded Estuarine Marshes.” Estuarine Coastal and Shelf Science 37: 371-386.

Craft, C., J. Reader, J. N. Sacco, and S. W. Broome. 1999. "Twenty-Five Years of Ecosystem Development of Constructed Spartina alterniflora (Loisel) Marshes." Ecological Applications 9: 1,405-1,419.

Craft, C., J. Clough, J. Ehman, S. Joye, R. Park, S. Pennings, H. Guo, and M. Machmuller. 2008. "Forecasting the Effects of Accelerated Sea-Level Rise on Tidal Marsh Ecosystem Services." Frontiers in Ecology and the Environment 7: 73-78.

Croft, A. L., L. A. Leonard, T. D. Alphin, L. B. Cahoon, and M. H. Posey. 2006. "The Effects of Thin Layer Sand Renourishment on Tidal Marsh Processes: Masonboro Island, North Carolina." Estuaries and Coasts 29: 737-750.

Currin, C. A., W. S. Chappell, and A. Deaton. 2010. "Developing Alternative Shoreline Armoring Strategies: The Living Shoreline Approach in North Carolina." In Puget Sound Shorelines and the Impacts of Armoring-Proceedings of a State of the Science Workshop, edited by H. Shipman, M. N. Dethier, G. Gelfenbaum, K. L. Fresh, and R. S. Dinicola, 91-102, May 2009. U.S. Geological Survey Scientific Investigations Report 2010-5254. Washington, DC: U.S. Department of the Interior.

Dale, P. E. R. 2007. "Assessing Impacts of Habitat Modification on a Subtropical Salt Marsh: 20 Years of Monitoring." Wetlands Ecology and Management 16: 77-87.

Davy, A. J., M. J. H. Brown, H. L. Mossman, and A. Grant. 2011. “Colonization of a Newly Developing Salt Marsh: Disentangling Independent Effects of Elevation and Redox Potential on Halophytes." Journal of Ecology 99: 1,350-1,357.

Day, J. W., Jr., and P. H. Templet. 1989. "Consequences of Sea Level Rise: Implications from the Mississippi Delta.” Coastal Management 17: 241-257.

Day, J. W., Jr., D. Pont, P. F. Hensel, and C. Ibanez. 1995. "Impacts of Sea-Level Rise on Deltas in the Gulf of Mexico and the Mediterranean: The Importance of Pulsing Events to Sustainability." Estuaries 18: 636-647.

Day, J. W., Jr., J. F. Martin, L. Cardoch, and P. H. Templet. 1997. "System Functioning as a Basis for Sustainable Management of Deltaic Ecosystems." Coastal Management 25: 115-153. 
Day, J. W., Jr., J. Barras, E. Clairain, J. Johnston, D. Justic, G. P. Kemp, J. Y. Ko, R. Lane, W. J. Mitsch, G. Steyer, P. Templet, and A. Yanez-Arancibia. 2005. "Implications of Global Climatic Change and Energy Cost and Availability for the Restoration of the Mississippi Delta." Ecological Engineering 24: 253-265.

Day, J. W., D. F. Boesch, E. J. Clairain, G. P. Kemp, S. B. Laska, W. J. Mitsch, K. Orth, H. Mashriqui, D. J. Reed, L. Shabman, C. A. Simenstad, B. J. Streever, R. R. Twilley, C. C. Watson, J. T. Wells, and D. F. Whigham. 2007. "Restoration of the Mississippi Delta: Lessons from Hurricanes Katrina and Rita.” Science 315: $1,679-1,684$.

Day, J. W., R. R. Christian, D. M. Boesch, A. Yáñez-Arancibia, J. Morris, R. R. Twilley, L. Naylor, L. Schaffner, and C. Stevenson. 2008. "Consequences of Climate Change on the Ecogeomorphology of Coastal Wetlands." Estuaries and Coasts 31: 477491.

Day, J. W., G. P. Kemp, D. J. Reed, D. R. Cahoon, R. M. Boumans, J. M. Suhayda, and R. Gambrell. 2011. "Vegetation Death and Rapid Loss of Surface Elevation in Two Contrasting Mississippi Delta Salt Marshes: The Role of Sedimentation, Autocompaction, and Sea-Level Rise.” Ecological Engineering 37: 229-240.

Day, J. W., R. R. Lane, C. F. D’Elia, A. R. H. Wiegman, J. S. Rutherford, G. P. Shaffer, C. G. Brantley, and G. P. Kemp. 2016. "Large Infrequently Operated River Diversions for Mississippi Delta Restoration." Estuarine, Coastal and Shelf Science 183: 292-303.

DeLaune, R. D., S. R. Pezeshki, J. H. Pardue, J. H. Whitcomb, and W. H. Patrick, Jr. 1990. "Some Influences of Sediment Addition to a Deteriorating Salt Marsh in the Mississippi River Deltaic Plain: A Pilot Study.” Journal of Coastal Research 6: 181-188.

Deng, Z., S. An, C. Zhao, L. Chen, C. Zhou, Y. Zhi, and H. Li. 2008. "Sediment Burial Stimulates the Growth and Propagule Production of Spartina alterniflora Loisel." Estuarine, Coastal and Shelf Science 76: 818-826.

DiGennaro, B., D. Reed, C. Swanson, L. Hastings, Z. Hymanson, M. Healey, S. Siegel, S. Cantrell, and B. Herbold. 2012. "Using Conceptual Models in Ecosystem Restoration Decision Making: An Example from the Sacramento-San Joaquin River Delta, California.” San Francisco Estuary and Watershed Science 10: 1-15.

Donnelly, J. P., and M. D. Bertness. 2001. "Rapid Shoreward Encroachment of Salt Marsh Cordgrass in Response to Accelerated Sea-Level Rise.” PNAS 98: 14,218-14,223.

Eertman, R. H. M., B. A. Kornman, E. Stikvoort, and H. Verbeek. 2002. "Restoration of the Sieperda Tidal Marsh in the Scheldt Estuary, The Netherlands." Restoration Ecology 10: 438-449.

Elliott, M., D. Burdon, K. L. Hemingway, and S. E. Apitz. 2007. "Estuarine, Coastal and Marine Ecosystem Restoration: Confusing Management and Science-A Revision of Concepts." Estuarine Coastal and Shelf Science 74: 349-366.

El-Raey, M., K. R. Dewidar, and M. El-Hattab. 1999. "Adaptation to the Impacts of sea Level Rise in Egypt.” Mitigation and Adaptation Strategies for Global Change 4: 343-361. 
Engelhart, S. E., B. P. Horton, B. C. Douglas, W. R. Peltier, and T. E. Tornqvist. 2009. "Spatial Variability of Late Holocene and Early $20^{\text {th }}$ Century Sea-Level Rise along the Atlantic Coast of the United States." Geology 37: 1,115-1,118.

Ericson, J. P., C. J. Vorosmarty, S. L. Dingman, L. G. Ward, and M. Meybeck. 2006. "Effective Sea-Level Rise and Deltas: Causes of Change and Human Dimension Implications." Global and Planetary Change 50: 63-82.

Erwin, M. R., G. M. Sanders, and D. J. Prosser. 2004. "Changes in Lagoonal Marsh Morphology at Selected Northeastern Atlantic Coast Sites of Significance to Migratory Seabirds." Wetlands 24: 891-903.

Ewel, K. C., C. Cressa, R. T. Kneib, P. S. Lake, L. A. Levin, M. A. Palmer, P. Snelgrove, and D. H. Wall. 2001. "Managing Critical Transition Zones.” Ecosystems 4: 452-460.

Ezer, T., and L. P. Atkinson. 2014. "Accelerated Flooding along the U.S. East Coast: On the Impact of Sea-Level Rise, Tides, Storms, the Gulf Stream, and the North Atlantic Oscillations." Earth’s Future 2: 1-21.

Ezer, T., L. P. Atkinson, W. B. Corlett, and J. L. Blanco. 2013. "Gulf Stream's Induced Sea Level Rise and Variability along the U.S. Mid-Atlantic Coast.” Journal of Geophysical Research: Oceans 118: 1-13.

Fagherazzi, S., and A. M. Priestas. 2010. "Sediments and Water Fluxes in a Muddy Coastline: Interplay between Waves and Tidal Channel Hydrodynamics.” Earth Surface Processes and Landforms 35: 284-293.

Fagherazzi, S., M. L. Kirwan, S. M. Mudd, G. R. Guntenspergen, S. Temmerman, A. D'Alpaos, J. van de Koppel, J. M. Rybczyk, E. Reyes, C. Craft, and J. Clough. 2012. "Numerical Models of Salt Marsh Evolution: Ecological, Geomorphic, and Climatic Factors.” Rev. Geophys. 50: RG1002. doi:10.1029/2011RG000359.

Fagherazzi, S., G. Mariotti, P. Wiberg, and K. McGlathery. 2013. "Marsh Collapse Does Not Require Sea Level Rise.” Oceanography 26: 70-77.

Feagin, R. A., and X. B. Wu. 2006. "Spatial Pattern and Edge Characteristics in Restored Terrace Versus Reference Salt Marshes in Galveston Bay.” Wetlands 26: 1,0041,011 .

Feagin, R. A., S. M. Lozada-Bernard, T. M. Ravens, I. Moller, K. M. Yeager, and A. H. Baird. 2009. "Does Vegetation Prevent Wave Erosion of Salt Marsh Edges?" PNAS 106: 10,109-10,113.

Ferland, F. A. 1990. Holocene Depositional History of the Southern New Jersey Barrier and Backbarrier Regions. TR-CERC-90-2. Vicksburg, MS: U.S. Army Corps of Engineers, Coastal Engineering Research Center.

Fischenich, C. 2008. The Application of Conceptual Models to Ecosystem Restoration. EBA Technical Notes Collection. ERDC/EBA TN-08-1. Vicksburg, MS: U.S. Army Engineer Research and Development Center. www.wes.army.mil/el/emrrp.

FitzGerald, D., M. S. Fenster, B. A. Argow, and I. V. Buynevich. 2008. "Coastal Impacts Due to Sea-Level Rise.” Annual Reviews of Earth and Planetary Sciences 36: 601-647. 
Ford, M. A., D. R. Cahoon, and J. C. Lynch. 1999. "Restoring Marsh Elevation in a Rapidly Subsiding Salt Marsh by Thin-Layer Deposition of Dredged Material.” Ecological Engineering 12: 189-205.

French, J. R. 1993. "Numerical Simulation of Vertical Marsh Growth and Adjustment to Accelerated Sea-Level Rise, North Norfolk, U.K." Earth Surface Processes and Landforms 18: 63-81.

French, J. R. 2006. “Tidal Marsh Sedimentation and Resilience to Environmental Change: Exploratory Modelling of Tidal, Sea-Level, and Sediment Supply Forcing in Predominately Allochthonous Systems.” Marine Geology 235: 119-136.

French, J. R., and D. R. Stoddard 1992. "Hydrodynamics of Salt Marsh Creek Systems: Implications for Marsh Morphological Development and Material Exchange." Earth Surface Processes and Landforms 17: 235-252.

Friedrichs, C. T., and J. E. Perry. 2001. "Tidal Salt Marsh Morphodynamics: A Synthesis.” Journal of Coastal Research 27: 7-37.

Galbraith, H., R. Jones, R. Park, J. Clough, S. Herrod-Julius, B. Harrington, and G. Page. 2002. "Global Climate Change and Sea Level Rise: Potential Losses of Intertidal Habitat for Shorebirds." Waterbirds 25: 173-183.

Ganju, N. K., M. L. Kirwan, P. J. Dickhudt, G. R. Guntenspergen, D. R. Cahoon, and K. D. Kroeger. 2015. "Sediment Transport-Based Metrics of Wetland Stability." Geophysical Research Letters 42: 7,992-8,000.

Garster, J. G., M. W. Huber, and K. D. White. 2015. Screening-Level Assessment of Projects with Respect to Sea Level Change. Civil Works Technical Report, CWTS 2015-16. Washington, DC: U.S. Army Corps of Engineers.

Gedan, K. B., B. R. Silliman, and M. D. Bertness. 2009. "Centuries of Human-Driven Change in Salt Marsh Ecosystems.” Annual Review of Marine Science 1: 117-141.

Gesch, D. B. 2009. "Analysis of LiDAR Elevation Data for Improved Identification and Delineation of Lands Vulnerable to Sea-Level Rise.” Journal of Coastal Research 53: 49-58.

Glick, P., J. Clough, A. Polaczyk, B. Couvillion, and B. Nunley. 2013. "Potential Effects of Sea-Level Rise on Coastal Wetlands in Southeastern Louisiana." Journal of Coastal Research 63: 211-233.

Golet, F. C., D. H. A. Myshrall, L. R. Oliver, P. W. C. Paton, and B. C. Tefft. 2012. "Role of Science and Partnerships in Salt Marsh Restoration at the Galilee Bird Sanctuary, Narragansett, Rhode Island." In Tidal Marsh Restoration: A Synthesis of Science and Management, edited by C. T. Roman and D. M. Burdick. Washington, DC: Island Press.

Gornitz, V., S. Couch, and E. K. Hartig. 2002. "Impacts of Sea-Level Rise in the New York City Metropolitan Area." Global and Planetary Changes 32: 61-88.

Graham, S. A., and I. A. Mendelssohn. 2013. "Functional Assessment of Different Sediment Slurry Applications in a Deteriorating Brackish Marsh." Ecological Engineering 51: 264-274. 
Griggs, G., J. Árvai, D. Cayan, R. DeConto, J. Fox, H. A. Fricker, R. E. Kopp, C. Tebaldi, and E. A. Whiteman. 2017. Rising Seas in California: An Update on Sea-Level Rise Science. California Ocean Protection Council Science Advisory Team Working Group. California Ocean Science Trust, April 2017. http://www.opc.ca.gov/webmaster/ftp/pdf/docs/rising-seas-in-california-an-update-on-sealevel-rise-science.pdf.

Gulf Coast Ecosystem Restoration Council, Restore. n.d. Resources and Ecosystems Sustainability, Tourist Opportunities, and Revived Economies of the Gulf Coast States Act (RESTORE Act) Initial Funded Priorities List. https://www.restorethegulf.gov/sites/default/files/FPL_FINAL_Dec9Vote_EC_Library_Links.pdf

Hackney, C. T. 2000. "Restoration of Coastal Habitats: Expectation and Reality." Ecological Engineering 15: 165-170.

Hackney, C. T., and W. J. Cleary. 1987. "Saltmarsh Loss in Southeastern North Carolina: Importance of Sea-Level Rise and Inlet Dredging." Journal of Coastal Research 3: 93-97.

Hall, J. A., S. Gill, J. Obeysekera, W. Sweet, K. Knuuti, and J. Marburger. 2016. Regional Sea Level Scenarios for Coastal Risk Management: Managing the Uncertainty of Future Sea Level Change and Extreme Water Levels for Department of Defense Coastal Sites Worldwide. U.S. Department of Defense, Strategic Environmental Research and Development Program.

Haltiner, J., J. B. Zedler, G. D. Williams, and J. C. Callaway. 1997. “Influence of Physical Processes on the Design, Functioning, and Evolution of Restored Tidal Wetlands in California." Wetlands Ecology and Management 4: 73-91.

Hartig, E. K., V. Gornitz, A. Kolker, F. Mushacke, and D. Fallon. 2002. "Anthropogenic and Climate-Change Impacts on Salt Marshes of Jamaica Bay, New York City." Wetlands 22: 71-89.

Healey, M. C., P. L. Angermeier, K. W. Cummins, T. Dunne, W. J. Kimmerer, G. M. Kondolf, P. B. Moyle, D. D. Murphy, D. T. Patten, D. J. Reed, R. B. Spies, and R. H. Twiss. 2007. Conceptual Models and Adaptive Management in Ecological Restoration: The CALFED Bay-Delta Environmental Restoration Program. https://www.researchgate.net/publication/255653467_Conceptual_Models_and_Adaptive_M anagement_in_Ecological_Restoration_The_CALFED_Bay-

Delta_Environmental_Restoration_Program.

Heberger, M., H. Cooley, P. Herrera, P. H. Gleick, and E. Moore. 2009. The Impacts of Sea-Level Rise on the California Coast. California Climate Change Center, CEC500-2009-024-F.

Heilman, D. J., J. T. Darnell, and M. C. Perry. 2007. "Sediment Analysis for Habitat Restoration: Adaption of Open-Coast Beach Nourishment Principles.” Proceedings of the Sixth International Symposium on Coastal Engineering and Science of Coastal Sediment Process, 1-9.

Hine, S. K. 2015. Adapting to Rising Sea Levels in San Francisco Bay: The Potential for Thin Layer Sediment Application to Enhance Tidal Marsh Resiliency through This Century. Master's Projects. Paper 275. The University of San Francisco. 
Hinkle, R. L., and W. J. Mitsch. 2005. "Salt Marsh Vegetation Recovery at Salt Hay Farm Wetland Restoration Sites on Delaware Bay.” Ecological Engineering 25: 240251.

Hood, W. G. 2002. "Landscape Allometry: From Tidal Channel Hydraulic Geometry to Benthic Ecology." Canadian Journal of Fisheries and Aquatic Sciences 59: $1,418-1,427$.

Hughes, R. G. 2004. "Climate Change and Loss of Saltmarshes: Consequences for Birds." Ibis 146: 21-28.

Jarvis, J. C. 2010. Vertical Accretion Rates in Coastal Louisiana: A Review of the Scientific Literature. ERDC/EL TN-10-5. Vicksburg, MS: U.S. Army Engineer Research and Development Center.

Karamouz, M., Z. Zahmatkesh, and S. Nazif. 2013. Realization of Sea Level Rise Using Climate Variables Considering Climate Change Scenarios. World Environmental and Water Resources Congress 2013, 1,402-1,409. doi:10.1061/9780784412947.138.

Kentula, M. E. 2000. "Perspectives on Setting Success Criteria for Wetland Restoration.” Ecological Engineering 15: 199-209.

Kirwan, M. L., and G. R. Guntenspergen. 2012. "Feedbacks between Inundation, Root Production, and Shoot Growth in a Rapidly Submerging Brackish Marsh." Journal of Ecology 100: 764-770.

Kirwan, M. L., and J. P. Megonigal. 2013. "Tidal Wetland Stability in the Face of Human Impacts and Sea-Level Rise.” Nature 504: 53-60.

Kirwan, M. L., and A. B. Murray. 2007. "A Coupled Geomorphic and Ecological Model of Tidal Marsh Evolution.” PNAS 104: 6,118-6,122.

Kirwan, M., and S. Temmerman. 2009. "Coastal Marsh Response to Historical and Future Sea-Level Rise.” Quaternary Science Reviews 28: 1,801-1,808.

Kirwan, M. L., G. R. Guntenspergen, A. D’Alpaos, J. T. Morris, S. M. Mudd, and S. Temmerman. 2010. "Limits on the Adaptability of Coastal Marshes to Rising Sea Level.” Geophysical Research Letters 37: L23401.

Kolker, A. S., M. A. Allison, and S. Hameed. 2011. "An Evaluation of Subsidence Rates and Sea-Level Variability in the Northern Gulf of Mexico." Geophys. Res. Lett. 38: L21404.

Konisky, R. A., D. M. Burdick, M. Dionne, and H. A. Neckles. 2006. “A Regional Assessment of Salt Marsh Restoration and Monitoring in the Gulf of Maine." Restoration Ecology 14: 516-525.

Koo, B. J., J. G. Je, and H. J. Woo. 2011. "Experimental Restoration of a Salt Marsh with Some Comments on Ecological Restoration of Coastal Vegetated Ecosystems in Korea." Ocean Science Journal 46: 47-53. 
La Peyre, M. K., B. Gossman, and B. P. Piazza. 2009. "Short- and Long-Term Response of Deteriorating Brackish Marshes and Open-Water Ponds to Sediment Enhancement by Thin-Layer Dredge Disposal." Estuaries and Coasts 32: 390402.

Lawrence, D. S. L., J. R. L. Allen, and G. M. Havelock. 2004. "Salt Marsh Morphodynamics: An Investigation of Tidal Flows and Marsh Channel Equilibrium.” Journal of Coastal Research 20: 301-316.

Lewis, R. R. 2000. "Ecologically Based Goal Setting in Mangrove Forest and Tidal Marsh Restoration.” Ecological Engineering 15: 191-198.

Linthurst, R. A., and E. D. Seneca. 1979. "The Effects of Standing Water and Drainage Potential of the Spartina alterniflora-Substrate Complex in a North Carolina Salt Marsh." Estuarine and Coastal Marine Science 11: 41-52.

Little, C. M., R. M. Horton, R. E. Kopp, M. Oppenheimer, and S. Yip. 2015. "Uncertainty in Twenty-First Century CMIP5 Sea Level Projections." Journal of Climate 28: 838-852.

Lowe, J., and J. Bourgeois. 2015. "Science Foundation Chapter 2 - The Projected Evolution of Baylands Habitats.” In Baylands Ecosystem Habitat Goals Science Update 2015. Prepared by the San Francisco Bay Area Wetlands Ecosystem Goals Project. Oakland, CA: California State Coastal Conservancy.

MacBroom, J. G., and R. Schiff. 2012. "Predicting the Hydrologic Response of Salt Marshes to Tidal Restoration.” In Tidal Marsh Restoration: A Synthesis of Science and Management, edited by C. T. Roman and D. M. Burdick. Washington, DC: Island Press.

Mariotti, G., and S. Fagherazzi. 2013. "Critical Width of Tidal Flats Triggers Marsh Collapse in the Absence of Sea-Level Rise." PNAS 10(14): 5,353-5,356.

Martin, J. F., E. Reyes, G. P. Kemp, H. Mashriqui, and J. W. Day, Jr. 2002. "Landscape Modeling of the Mississippi Delta." BioScience 52: 356-365.

McCall, B. D., and S. C. Pennings. 2012. "Geographic Variation in Salt Marsh Structure and Function." Oecologia 170: 777-787.

Meehl, G. A., A. Hu, C. Tebaldi, J. M. Arblaster, W. M. Washington, H. Teng, B. M. Sanderson, T. Ault, W. G. Strand, and J. B. White III. 2012. "Relative Outcomes of Climate Change Mitigation Related to Global Temperatures versus Sea-Level Rise." Nature Climate Change 2: 576-580.

Mendelssohn, I. A., and N. L. Kuhn. 2003. "Sediment Subsidy: Effects on Soil-Plant Responses in a Rapidly Submerging Coastal Salt Marsh.” Ecological Engineering 21: $115-128$.

Mendelssohn, I. A., and K. L. McKee. 1988. "Spartina alterniflora Die-Back in Lousiana: Time-Course Investigation of Soil.” Journal of Ecology 76: 509-521.

Mendelssohn, I. A., and E. D. Seneca. 1980. "The Influences of Soil Drainage on the Growth of Salt Marsh Cordgrass Spartina alterniflora in North Carolina." Estuarine and Coastal Marine Science 11: 27-40. 
Meyssignac, B., and A. Cazenave. 2012. "Sea Level: A Review of Present-Day and RecentPast Changes and Variability." Journal of Geodynamics 58: 96-109.

Milne, G. A., W. R. Gehrels, C. W. Hughes, and M. E. Tamisiea. 2009. "Identifying the Causes of Sea-Level Change.” Nature Geoscience 2: 471-478.

Mitsch, W. J., and J. G. Gosselink. 2000. Wetlands. 3rd edition. New Jersey: John Wiley \& Sons, Inc.

Moorhead, K. K., and M. M. Brinson. 1995. "Response of Wetlands to Rising Sea Level in the Lower Coastal Plain of North Carolina.” Ecological Applications 5: 261-271.

Morris, J. T., P. V. Sundareshwar, C. T. Nietch, B. Kjerfve, and D. R. Cahoon. 2002.

"Response of Coastal Wetlands to Rising Sea Level." Ecology 83: 2,869-2,877.

Moser, S. 2005. "Impact Assessments and Policy Responses to Sea-Level Rise in Three US States: An Exploration of Human-Dimension Uncertainties." Global Environmental Change 15: 353-369.

Mote, P., A. Petersen, S. Reeder, H. Shipman, and L. W. Binder. 2008. Sea Level Rise in the Coastal Waters of Washington State. A report by University of Washington Climate Impact Group and Washington Department of Ecology. http://www.cses.washington.edu/db/pdf/moteetalslr579.pdf.

Mudd, S. 2011. "The Life and Death of Salt Marshes in Response to Anthropogenic Disturbance of Sediment Supply." Geology 39: 511-512.

Mudd, S. M., S. M. Howell, and J. T. Morris. 2009. "Impact of Dynamic Feedbacks between Sedimentation, Sea-Level Rise, and Biomass Production on NearSurface Marsh Stratigraphy and Carbon Accumulation." Estuarine, Coastal and Shelf Science 82: 377-389.

Neckles, H. A., M. Dionne, D. M. Burdick, C. T. Roman, R. Buchsbaum, and E. Hutchins. 2002. "A Monitoring Protocol to Assess Tidal Restoration of Salt Marshes on Local and Regional Scales.” Restoration Ecology 10: 556-563.

Neckles, H. A., G. R. Guntenspergen, W. G. Shriver, N. P. Danz, W. A. Wiest, J. L. Nagel, and J. H. Olker. 2013. Identification of Metrics to Monitor Salt Marsh Integrity on National Wildlife Refuges in Relation to Conservation and Management Objectives. Final Report to USFWS, Northeast Region. Laurel, MD: USGS Patuxent Wildlife Research Center.

Nicholls, R. J. 2003. "Case Study on Sea-Level Rise Impacts." OECD Workshop on the Benefits of Climate Policy: Improving Information for Policy Makers. Organization for Economic Co-operation and Development, ENV/EPOC/GSP(2003)9/FINAL.

Nicholls, R. J., and A. Cazenave. 2010. "Sea-Level Rise and Its Impact on Coastal Zones." Science 328: 517-1520.

Nicholls, R. J., and J. A. Lowe. 2006. "Climate Stabilization and Impacts of Sea-Level Rise.” In Avoiding Dangerous Climate Change, edited by H. J. Schellnhuber, 195-202. New York: Cambridge University Press. 
National Oceanic and Atmospheric Administration (NOAA). 2015. Guidance for Considering the Use of Living Shorelines. https://www.habitatblueprint.noaa.gov/wpcontent/uploads/2018/01/NOAA-Guidance-for-Considering-the-Use-of-LivingShorelines_2015.pdf.

National Park Service (NPS), U.S. Department of the Interior, Jamaica Bay Institute, Gateway National Recreational Area. 2004. "Jamaica Bay's Disappearing Marshes.” In Proceedings. New York Aquarium Scientific Symposium and Public Forum.

National Research Council (NRC). 1995. Science, Policy, and the Coast: Improving Decision-Making. Washington, DC: National Academic Press.

National Research Council (NRC). 2010. A Scientific Assessment of Alternatives for Reducing Water Management Effects on Threatened and Endangered Fishes in California's Bay Delta. Water Science and Technology Board \& Ocean Studies Board, National Academy of Sciences. Washington DC: National Academy Press.

New York City Department of Environmental Protection (NYC DEP). 2007. Jamaica Bay Watershed Protection Plan. Volume 2. http://www.nyc.gov/html/dep/html/dep_projects/jamaica_bay.shtml.

Olff, H., J. De Leeuw, J. P. Bakker, R. J. Platerink, and H. J. van Wijnen. 1997. "Vegetation Succession and Herbivory in a Salt Marsh: Changes Induced by Sea Level Rise and Silt Deposition along an Elevation Gradient.” Journal of Ecology 85: 799-814.

O’Neill, V. 2015. Long Island Sound Tidal Wetlands Loss Workshop. Workshop Proceedings and Recommendations to the Management Committee of the Long Island Sound Study. October 22-23, 2014. Port Jefferson, NY. http://longislandsoundstudy.net/our-vision-and-plan/thriving-habitats-and-abundantwildlife/2014-lis-twl-wksp/.

Orr, M., S. Crooks, and P. B. Williams. 2003. "Will Restored Tidal Marshes be Sustainable?” San Francisco Estuary and Watershed Science 1: 1-33.

Orson, R. A., R. S. Warren, and W. A. Niering. 1998. "Interpreting Sea-Level Rise and Rates of Vertical Marsh Accretion in a Southern New England Tidal Salt Marsh.” Estuarine, Coastal and Shelf Science 47: 19-429.

Palaima, A. 2012. Ecology, Conservation, and Restoration of Tidal Marshes: The San Francisco Estuary. Berkeley, CA: University of California Press..

Palermo, M. R., and E. A. Dardeau, Jr. 1994. "Guidance for Wetland Restoration with Dredged Material.” Dredging ‘94. Vicksburg, MS: U.S. Army Engineer Waterways Experiment Station.

Pennings, S. C., and M. D. Bertness. 2001. "Salt Marsh Communities." In Marine Community Ecology, edited by M. D. Bertness, S. D. Gaines, and M. Hay, 289316. Sunderland, MA: Sinauer Associates.

Pethick, J. 1993. "Shoreline Adjustments and Coastal Management: Physical and Biological Processes under Accelerated Sea-Level Rise.” The Geographical Journal 2: 162-168. 
Pethick, J. 2001. “Coastal Management and Sea-Level Rise.” Catena 42: 307-322.

Piazza, B. P., P. D. Banks, and M. K. La Peyre. 2005. "The Potential for Created Oyster Shell Reefs as a Sustainable Shoreline Protection Strategy in Louisiana.” Restoration Ecology 13: 499-506.

Rahmstorf, S. 2007. “A Semi-Empirical Approach to Projecting Future Sea-Level Rise.” Science 315: 368-370.

Ravens, T. M., R. C. Thomas, K. A. Roberts, and P. H. Santschi, 2009. "Causes of Salt Marsh Erosion in Galveston Bay, Texas.” Journal of Coastal Research 252: 265272.

Ray, G. L. 2007. Thin Layer Disposal of Dredged Material on Marshes: A Review of the Technical and Scientific Literature. ERDC/EL TN-07-1. Vicksburg, MS: U.S. Army Engineer Research and Development Center.

Redfield, A. C. 1972. "Development of a New England Salt Marsh.” Ecological Monographs 42: 201-237.

Redmond, A. M. 2000. "Dredge and Fill Regulatory Constraints in Meeting the Ecological Goals of Restoration Projects.” Ecological Engineering 15: 181-189.

Reed, D. J. 1989. "Patterns of Sediment Deposition in Subsiding Coastal Salt Marshes, Terrebonne Bay, Louisiana: The Role of Winter Storms.” Estuaries 12: 222-227.

Reed, D. J. 1995. "The Response of Coastal Marshes to Sea-Level Rise: Survival or Submergence." Earth Surface Processes and Landforms 20: 39-48.

Reed, D. J. 2002. "Sea-Level Rise and Coastal Marsh Sustainability: Geological and Ecological Factors in the Mississippi Delta Plain.” Geomorphology 48: 233-243.

Reed, D. J., T. Spencer, A. L. Murray, J. R. French, and L. Leonard. 1999. "Marsh Surface Sediment Deposition and the Role of Tidal Creeks: Implications for Created and Managed Coastal Marshes.” Journal of Coastal Conservation 5: 81-90.

Roman, C. T., J. A. Peck, J. R. Allen, J. W. King, and P. G. Appleby. 1997. “Accretion of a New England (U.S.A.) Salt Marsh in Response to Inlet Migration Storms and SeaLevel Rise." Estuarine, Coastal and Shelf Science 45: 717-727.

Rounds, R. A., R. M. Erwin, and J. H. Porter. 2004. "Nest-Site Selection and Hatching Success of Waterbirds in Coastal Virginia: Some Results of Habitat Manipulation.” Journal of Field Ornithology 75: 317-329.

Rozas, L. P., and T. J. Minello. 2001. "Marsh Terracing as a Wetland Restoration tool for Creating Fishery Habitat." Wetlands 3: 327-341.

Rozas, L. P., P. Caldwell, and T. J. Minello. 2005. "The Fishery Value of salt Marsh Restoration Projects.” Journal of Coastal Research 40: 37-50.

Sallenger, A. H., Jr., K. S. Doran, and P. A. Howd. 2012. "Hotspot of Accelerated SeaLevel Rise on the Atlantic Coast of North America." Nature Climate Change 2: 884-888. 
Scarton, F., J. W. Day, Jr, A. Rismondo, G. Cecconi, and D. Are. 2000. "Effects of an Intertidal Sediment Fence on Sediment Elevation and Vegetation Distribution in a Venice (Italy) Lagoon Salt Marsh.” Ecological Engineering 16: 223-233.

Schile, L. M., J. C. Callaway, J. T. Morris, D. Stralberg, V. T. Parker, and M. Kell. 2014. "Modeling Tidal Marsh Distribution with Sea-Level Rise: Evaluating the Role of Vegetation, Sediment, and Upland Habitat in Marsh Resiliency." PLoS ONE 9: e88760.

Schrift, A. M., I. A. Mendelssohn, and M. D. Materne. 2008. "Salt Marsh Restoration with Sediment-Slurry Amendments Following a Drought-Induced Large Scale Disturbance." Wetlands 28: 1071-1085.

Short, F. T., D. M. Burdick, C. A. Short, R. C. Davis, and P. A. Morgan. 2000. "Developing Success Criteria for Restored Eelgrass, Salt Marsh and Mud Flat Habitat." Ecological Engineering 15: 239-252.

Shreffler, D. K., R. M. Thom, M. J. Scott, K. F. Wellman, M. A. Walters, and M. Curran. 1995. National Review of Non-Corps Environmental Restoration Projects. IWR Report 95-R- 12. Pacific Northwest National Laboratory, Richland, Washington; final report prepared for U.S. Army Corps of Engineers, Institute for Water Resources, Alexandria, VA.

Simenstad, C., D. Reed, and M. Ford. 2006. "When is Restoration Not? Incorporating Landscape-Scale Processes to Restore Self-Sustaining Ecosystems in Coastal Wetland Restoration.” Ecological Engineering 26: 27-39.

Slocum, M. G., I. A. Mendelssohn, N. L. Kuhn. 2005. "Effects of Sediment Slurry Enrichment on Salt Marsh Rehabilitation: Plant and Soil Response over Seven Years." Estuaries 28: 519-528.

Stagg, C. L., and I. A. Mendelssohn. 2010. "Restoring Ecological Function to a Submerged Salt Marsh.” Restoration Ecology 18: 10-17.

Stevenson, J. C., L. G. Ward, and M. S. Kearney. 1986. "Vertical Accretion in Marshes with Varying Rates of Sea Level Rise.” Estuarine Variability, 241-26o. New York: Academic Press, Inc.

Steyer, G. D., C. E. Sasser, J. M. Visser, E. M. Swenson, J. A. Nyman, and R. C. Raynie. 2002. "A Proposed Coast-Wide Reference Monitoring System for Evaluating Wetland Restoration Trajectories in Louisiana.” Journal of Environmental Monitoring and Assessment 81: 107-117.

Stralberg, D., M. Brennan, J. C. Callaway, J. K. Wood, L. M. Schile, D. Jongsomjit, M. Kelly, V. T. Parker, and S. Crooks. 2011. "Evaluating Tidal Marsh Sustainability in the Face of Sea-Level Rise: A Hybrid Modeling Approach Applied to San Francisco Bay." PLoS One 6: e27388.

Stumpf, R. P. 1983. "The Process of Sedimentation on the Surface of a Salt Marsh." Estuarine, Coastal and Shelf Science 17: 495-508. 
Sweet, W., J. Park, J. Marra, C. Zervas, and S. Gill. 2014. Sea Level Rise and Nuisance Flood Frequency Changes around the United States. NOS CO-OPS 073. Silver Spring, MD: Center for Operational Oceanographic Products and Services, National Ocean Service, National Oceanic and Atmospheric Administration.

Teal, J. M., and M. P. Weinstein. 2002. "Ecological Engineering, Design, and Construction Considerations for Marsh Restorations in Delaware Bay, USA. Ecological Engineering 18: 607-618.

Teal, J. M., and L. Weishar. 2005. "Ecological Engineering, Adaptive Management, and Restoration Management in Delaware Bay Salt Marsh Restoration.” Ecological Engineering 25: 304-314.

Temmerman, S., G. Govers, S. Wartel, and P. Mere. 2003. "Spatial and Temporal Factors Controlling Short-Term Sedimentation in a Salt and Freshwater Tidal Marsh, Scheldt Estuary, Belgium, SW Netherlands." Earth Surface Processes and Landforms 28: 739-755.

Temmerman, S., G. Govers, S. Wartel, and P. Meire. 2004. "Modelling Estuarine Variations in Tidal Marsh Sedimentation: Response to Changing Sea Level and Suspended Sediment Concentrations." Marine Geology 212: 1-19.

Temmerman, S., P. Meire, T. J. Bouma, P. M. J. Herman, T. Ysebaert, and H. J. De Vriend. 2013. "Ecosystem-Based Coastal Defense in the Face of Global Change." Nature 504: 79-83.

Thayer, G. W., and M. E. Kentula. 2005. "Coastal Restoration: Where Have We Been, Where Are We Now, and Where Should We Be Going?” Journal of Coastal Research 40: 1-5.

Thom, R. M. 1997. "System-Development Matrix for Adaptive Management of Coastal Ecosystem Restoration Projects.” Ecological Engineering 8: 219-232

Thom, R. M. 2000. "Adaptive Management of Coastal Ecosystem Restoration Projects." Ecological Engineering 15: 365-372.

Thom, R. M., and K. F. Wellman. 1996. Planning Aquatic Ecosystem Restoration Monitoring Programs. IWR Report 96-R-23. Pacific Northwest National Laboratory, Richland, Washington; final report prepared for U.S. Army Corps of Engineers, Institute for Water Resources, Alexandria, VA.

Thorne, K. M., G. M. MacDonald, R. F. Ambrose, K. J. Buffington, C. M. Freeman, C. N. Janousek, L. N. Brown, J. R. Holmquist, G. R. Guntenspergen, K. W. Powelson, P. L. Barnard, and J. Y. Takekawa. 2016. Effects of Climate Change on Tidal Marshes along a Latitudinal Gradient in California. U.S. Geological Survey Open-File Report 2016-1125. http://dx.doi.org/10.3133/ofr20161125.

Titus, J. G. 1988. "Alternatives for Protecting Coastal Wetlands from the Rising Sea." Greenhouse Effect, Sea-Level Rise and Coastal Wetlands, 151-152. EPA 230-0586-013. Washington, DC: U.S. Environmental Protection Agency. 
Titus, J. G., R. A. Park, S. P. Leatherman, J. R. Weggel, M. S. Greene, P. W. Mausel, S. Brown, C. Gaunt, M. Trehan, and G. Yohe. 1991. "Greenhouse Effect and Sea Level Rise: The Coast of Holding Back the Sea." Coastal Management 19: 171204.

Tobias, V. D., J. A. Nyman, R. D. DaLaune, and J. D. Foret. 2010. “Improving Marsh Restoration: Leaf Tissue Chemistry Identifies Factors Limiting Production in Spartina patens." Plant Ecology 207: 141-148.

Tol, R. S. J., R. J. T. Klein, and R. J. Nicholls. 2008. "Towards Successful Adaptation to Sea-Level Rise along Europe's Coasts.” Journal of Coastal Research 24: 432442.

Turner, R. E. 1997. "Wetland Loss in the Northern Gulf of Mexico: Multiple Working Hypotheses." Estuaries 20: 1-13.

Turner, R. E., and D. R. Cahoon, editors. 1987. Causes of Wetland Loss in the Coastal Central Gulf of Mexico. Volume I: Executive Summary. Final report submitted to Minerals Management Service, New Orleans, LA. Contract No. 14-12-000130252. OCS Study/MNIS 87-0119. New Orleans, LA.

Turner, R. E., J. J. Baustian, E. M. Swenson, and J. S. Spicer. 2006. "Wetland Sedimentation from Hurricanes Katrina and Rita.” Science 314: 449-452.

Twohig, T. M., and M. H. Stolt. 2011. "Soils-Based Rapid Assessment for Quantifying Changes in Salt Marsh Condition as a Result of Hydrologic Alteration." Wetlands 31: $955-963$.

U.S. Department of Interior (US DOI). 2015. Recommendations for Assessing the Effects of the DOI Hurricane Sandy Mitigation and Resilience Program on Ecological System and Infrastructure Resilience in the Northeast Coastal Region. The Department of the Interior Metrics Expert Group. Washington, DC: U.S. Department of the Interior.

U.S. Department of Interior Fish and Wildlife Service (US FWS). 2014a. Environmental Assessment for the Narrow River Estuary Resilience Restoration Program. Rhode Island National Wildlife Refuge Complex, Charlestown, RI.

US FWS. 2014b. Final Initial Study/Environmental Assessment for the Seal Beach National Wildlife Refuge Thin-Layer Salt Marsh Sediment Augmentation Pilot Project Orange County, California. San Diego National Wildlife Refuge Complex, Chula Vista, CA.

US FWS. 2014c. Finding of No Significant Impact for the Seal Beach National Wildlife Refuge Thin-Layer Salt Marsh Sediment Augmentation Pilot Project Orange County, California. San Diego National Wildlife Refuge Complex, Chula Vista, CA.

U.S. Army Corps of Engineers (USACE). 2009. Water Resources Policies and Authorities Incorporating Sea-Level Change Considerations in Civil Works Programs. EC 1165-2-211. Washington, DC: U.S. Army Corps of Engineers.

USACE. 2011. Sea-Level Change Considerations for Civil Works Programs. EC 1165-2212. Washington, DC: U.S. Army Corps of Engineers. 
USACE. 2013. Incorporating Sea Level Change in Civil Works Programs. ER 1100-28162. Washington, DC: U.S. Army Corps of Engineers.

USACE. 2014. Procedures to Evaluate Sea-Level Change: Impacts, Responses, and Adaptation. Technical Letter ETL 1100-2-1. Washington, DC: U.S. Army Corps of Engineers.

USACE. 2015. Climate Change Adaptation Plan - Update to 2014 Plan. Prepared by the USACE Climate Preparedness and Resilience Steering Committee. Washington, DC: U.S. Army Corps of Engineers.

Van Wijnen, H. J., and J. P. Bakker. 2000. "Long-Term Surface Elevation Change in Salt Marshes: A Prediction of Marsh Response to Future Sea-Level Rise. Estuarine, Coastal and Shelf Science 52: 381-390.

Verhoeven, J. T. A., B. Beltman, R. Bobbink, and D. F. Whigham, eds. 2006. Wetlands and Natural Resource Management. Springer E-Books. Berlin: Springer.

Walker, R., B. Bendall, and L. Wallendorf. 2011. "Defining Engineering Guidance for Living Shoreline Projects.” Coastal Engineering Practice 1,064-1,077. https://ascelibrary.org/doi/10.1061/41190\%28422\%2986.

Warren, R. S., and W. A. Niering. 1993. "Vegetation Change on a Northeast Tidal Marsh: Interaction of Sea-Level Rise and Marsh Accretion.” Ecology 74: 96-103.

Warren, R. S., P. E. Fell, R. Rozsa, A. H. Brawley, A. C. Orsted, E. T. Olson, V. Swamy, and W. A. Niering. 2002. "Salt Marsh Restoration in Connecticut: 20 Years of Science and Management." Restoration Ecology 10: 497-513.

Water Resources Development Act of 2007 (WRDA 2007). Section 2039 - Monitoring Ecosystem Restoration. Public Law 110-114.

Webb, E. L., D. A. Friess, K. W. Krauss, D. R. Cahoon, G. R. Guntenspergen, and J. Phelps. 2013. "A Global Standard for Monitoring Coastal Wetland Vulnerability to Accelerated Sea-Level Rise." Nature Climate Change 3: 458-465.

Weinstein, M. P., J. M. Teal, J. H. Balletto, and K. A. Strait. 2001. "Restoration Principles Emerging from One of the World's Largest Tidal Marsh Restoration Projects." Wetlands Ecology and Management 9: 387-407.

Weishar, L. L, J. M. Teal, and R. Hinkle. 2005. "Designing Large-Scale Wetland Restoration for Delaware Bay.” Ecological Engineering 25: 231-239.

Weston, N. B. 2014. "Declining Sediments and Rising Seas: An Unfortunate Convergence for Tidal Wetlands." Estuaries and Coasts 37: 1-23.

Wigand, C., T. Ardito, C. Chaffee, W. Ferguson, S. Paton, K. Raposa, C. Vandemoer, and E. Watson. 2015. "A Climate Change Adaptation Strategy for Management of Coastal Marsh Systems.” Estuaries and Coasts 40(3): 682-693.

Wilber, P. 1993. Environmental Effects of Dredging Technical Notes: Managing Dredged Material via Thin-Layer Disposal in Coastal Marshes. EEDP-01-32. Vicksburg, MS: U.S. Army Engineer Research and Development Center. 
Williams, G. D., and J. B. Zedler. 1999. "Fish Assemblage Composition in Constructed and Natural Tidal Marshes of San Diego Bay: Relative Influence of Channel Morphology and Restoration History." Estuaries 22: 702-716.

Willows, R. I., and R. K. Connell, eds. 2003. Climate Adaptation: Risk, Uncertainty and Decision-Making. United Kingdom Climate Impacts Programme (UKCIP) Technical Report. Oxford: UKCIP.

Wilson, G. L., and T. L. Prickett. 1998. Planning Considerations for Nearshore Placement of Mixed Dredged Sediments. Technical Note DOER-N3. Vicksburg, MS: U.S. Army Engineers Waterways Experiment Station.

Wu W., K. M. Yeager, M. S. Peterson, and R. S. Fulford. 2015. "Neutral Models as a Way to Evaluate the Sea Level Affecting Marshes Model (SLAMM)." Ecological Modelling 303: 55-69.

Zedler, J.B. 1996. "Coastal Mitigation in Southern California: The Need for a Regional Restoration Strategy.” Ecological Applications, 6:84-93.

Zedler, J. B. 2000. "Progress in Wetland Restoration Ecology." Tree 15: 402-407.

Zedler, J. B., and S. Kercher. 2005. "Wetland Resources: Status, Trends, Ecosystem Services, and Restorability." Annual Review of Environment and Resources 30: 39-74.

Zervas, C. 2009. Sea Level Variations of the United States 1854-2006. NOS CO-OPS 053. Silver Spring, MD: Center for Operational Oceanographic Products and Services, National Ocean Service, National Oceanic and Atmospheric Administration.

Zhao, Q., J. Bai, L. Huang, B. Gu, Q. Lu, and Z. Gao. 2016. "A Review of Methodologies and Success Indicators for Coastal Wetland Restoration.” Ecological Indicators 60: $442-452$. 
Table 1. Summary of predominant models used for assessing salt marsh responses to sea level rise.

\begin{tabular}{|c|c|c|c|c|c|c|}
\hline Reference & Model Name & Geographic Location & Model Type & Description & Input & Output \\
\hline $\begin{array}{l}\text { Fagherazzi et al. } \\
2012\end{array}$ & $\begin{array}{l}\text { Multiple } \\
\text { models }\end{array}$ & Multiple & $\begin{array}{l}\text { Conceptual, } \\
\text { numerical, } \\
\text { empirical and } \\
\text { physical models }\end{array}$ & $\begin{array}{l}\text { Overview of numerical models of salt marsh } \\
\text { evolution. This publication includes modeling of } \\
\text { sediment fluxes on the marsh platform (empirical } \\
\text { and physical models of marsh sedimentation), } \\
\text { modeling marsh boundary evolution, modeling } \\
\text { dynamics of marsh channels, modeling } \\
\text { belowground organic production, salt marsh } \\
\text { landscape-scale ecosystem modeling. }\end{array}$ & - & - \\
\hline French 1993 & - & Norfolk coast, UK & $\begin{array}{l}\text { Numerical } \\
\text { model }\end{array}$ & $\begin{array}{l}\text { One-dimensional mass balance model designed to } \\
\text { simulate vertical adjustment od marsh surfaces to } \\
\text { various combinations of sediment supply, tidal } \\
\text { levels, and regional subsidence. The historical } \\
\text { marsh growth under a scenario of long-term } \\
\text { eustatic stability but slow regional subsidence and } \\
\text { marsh response to various non-linear eustatic rise } \\
\text { scenarios for the next century were examined. }\end{array}$ & $\begin{array}{l}\text { Initial elevation, } \\
\text { sediment supply } \\
\text { parameters, } \\
\text { age/elevation } \\
\text { data }\end{array}$ & $\begin{array}{l}\text { Elevations } \\
\text { relative to } \\
\text { tidal frame }\end{array}$ \\
\hline French 2006 & Marsh-OD & $\begin{array}{l}\text { North America and } \\
\text { Europe (based on } \\
\text { data availability). }\end{array}$ & $\begin{array}{l}\text { Numerical } \\
\text { model }\end{array}$ & $\begin{array}{l}\text { Numerical mass balance modeling of the equivalent } \\
\text { parameter space and sensitivity of marsh } \\
\text { hydroperiod and sedimentation to sea level and } \\
\text { sediment supply changes. }\end{array}$ & - & - \\
\hline $\begin{array}{l}\text { Kirwan and } \\
\text { Murray } 2007\end{array}$ & - & - & $\begin{array}{l}\text { Numerical } \\
\text { model }\end{array}$ & $\begin{array}{l}\text { 3D model of tidal marsh accretion and channel } \\
\text { network development that couples physical } \\
\text { sediment transport processes with vegetation } \\
\text { biomass productivity. }\end{array}$ & $\begin{array}{l}\text { Sea level rise } \\
\text { rate, suspended } \\
\text { sediment } \\
\text { concentration, } \\
\text { and presence or } \\
\text { absence of } \\
\text { vegetation }\end{array}$ & $\begin{array}{l}\text { Evolution of } \\
\text { the marsh } \\
\text { channel- } \\
\text { platform } \\
\text { morphology } \\
\text { until it } \\
\text { reaches a } \\
\text { dynamic } \\
\text { equilibrium }\end{array}$ \\
\hline
\end{tabular}




\begin{tabular}{|c|c|c|c|c|c|c|}
\hline Reference & Model Name & Geographic Location & Model Type & Description & Input & Output \\
\hline $\begin{array}{l}\text { MacBroom and } \\
\text { Schiff } 2012\end{array}$ & - & - & $\begin{array}{l}\text { Multiple analog, } \\
\text { empirical, } \\
\text { mathematical, } \\
\text { and physical } \\
\text { models }\end{array}$ & $\begin{array}{l}\text { Hydraulic modeling of salt marshes includes the } \\
\text { characterization of the tidal prism, tidal action, the } \\
\text { marsh water budget, and flow types. Analog and } \\
\text { empirical models are typically used for small } \\
\text { projects with limited site constraints and } \\
\text { environmental risks to initiate design. Mathematical } \\
\text { models are most commonly used for evaluating } \\
\text { marsh hydraulics. Physical models are typically } \\
\text { used for larger studies and applied projects. }\end{array}$ & $\begin{array}{l}\text { Tidal prism and } \\
\text { runoff }\end{array}$ & $\begin{array}{l}\text { Flow types, } \\
\text { hydraulics, } \\
\text { and water } \\
\text { budget }\end{array}$ \\
\hline $\begin{array}{l}\text { Martin et al. } \\
2002\end{array}$ & $\begin{array}{l}\text { Multiple } \\
\text { models }\end{array}$ & Mississippi Delta & $\begin{array}{l}\text { Landscape } \\
\text { model }\end{array}$ & $\begin{array}{l}\text { Multiple landscape models were employed } \\
\text { including: the Coastal Ecological Landscape Spatial } \\
\text { Simulation, the Barataria-Terrebone Ecological } \\
\text { Landscape Spatial Simulation, and the Mississippi } \\
\text { Delta Model. These models can simulate highly } \\
\text { dynamic deltaic landscapes. }\end{array}$ & - & - \\
\hline $\begin{array}{l}\text { Morris et al. } \\
2002\end{array}$ & - & $\begin{array}{l}\text { North Inlet marsh in } \\
\text { South Carolina }\end{array}$ & $\begin{array}{l}\text { Theoretical } \\
\text { model }\end{array}$ & $\begin{array}{l}\text { Model of marsh sediment accretion used to } \\
\text { determine the optimal rate of RSLR at which the } \\
\text { equilibrium elevation and depth of tidal flooding are } \\
\text { optimal for plant growth. }\end{array}$ & - & $\begin{array}{l}\text { Optimal rate } \\
\text { of RSLR }\end{array}$ \\
\hline $\begin{array}{l}\text { Stralberg et al. } \\
2011\end{array}$ & - & San Francisco Bay & Hybrid Model & $\begin{array}{l}\text { This hybrid model involves mechanistic treatment of } \\
\text { marsh accretion dynamics and incorporates spatial } \\
\text { variation. Marsh accretion was estimated using the } \\
\text { Marsh98 model, which is based on mass balance } \\
\text { calculation, and applied in GIS to evaluate spatial } \\
\text { variation projections of marsh response to SLR. }\end{array}$ & $\begin{array}{l}\text { Elevation data, } \\
\text { suspended } \\
\text { sediment } \\
\text { concentration, } \\
\text { and organic } \\
\text { matter accretion }\end{array}$ & $\begin{array}{l}\text { Suspended } \\
\text { sediment } \\
\text { deposited } \\
\text { during tidal } \\
\text { inundation }\end{array}$ \\
\hline
\end{tabular}




\begin{tabular}{|c|c|c|c|c|c|c|}
\hline Reference & Model Name & Geographic Location & Model Type & Description & Input & Output \\
\hline $\begin{array}{l}\text { Schile et al. } \\
2014\end{array}$ & $\begin{array}{l}\text { Marsh } \\
\text { Equilibrium } \\
\text { Model } \\
\text { version } 3.76 \\
\text { and LiDAR } \\
\text { based model }\end{array}$ & San Francisco Bay & $\begin{array}{l}\text { Mechanistic } \\
\text { elevation based } \\
\text { model }\end{array}$ & $\begin{array}{l}\text { The mechanistic elevation based model was } \\
\text { incorporated using a rich dataset of plant } \\
\text { productivity and physical characteristics across tidal } \\
\text { marshes spanning a salinity gradient. The model } \\
\text { results were applied to a high spatial resolution } \\
\text { LiDAR-based digital elevation model to project } \\
\text { changes in marsh elevation and extent. The } \\
\text { combination of both models projects upland } \\
\text { migration under various SLR rates and suspended } \\
\text { sediment concentration scenarios. }\end{array}$ & $\begin{array}{l}\text { Initial rate of } \\
\text { SLR, mean sea } \\
\text { level, future sea } \\
\text { level, mean } \\
\text { higher high } \\
\text { water, } \\
\text { suspended } \\
\text { sediment } \\
\text { concentration, } \\
\text { and starting } \\
\text { marsh elevation }\end{array}$ & $\begin{array}{l}\text { Marsh } \\
\text { accretion }\end{array}$ \\
\hline $\begin{array}{l}\text { Temmerman et } \\
\text { al. } 2004\end{array}$ & MARSED & $\begin{array}{l}\text { Scheldt estuary, NW } \\
\text { Europe }\end{array}$ & $\begin{array}{l}\text { Zero- } \\
\text { dimensional } \\
\text { time-stepping } \\
\text { physically based } \\
\text { model }\end{array}$ & $\begin{array}{l}\text { The zero-dimensional time-stepping physically } \\
\text { based model called MARSED is used to simulate } \\
\text { varying rates of long-term tidal marsh accumulation } \\
\text { within an estuary in response to changes in SLR } \\
\text { rates and suspended sediment concentrations. }\end{array}$ & $\begin{array}{l}\text { Tidal regime, } \\
\text { suspended } \\
\text { sediment } \\
\text { concentration, } \\
\text { settling velocity }\end{array}$ & $\begin{array}{l}\text { Marsh } \\
\text { accumulation } \\
\text { rates }\end{array}$ \\
\hline $\begin{array}{l}\text { Van Wijnen and } \\
\text { Bakker } 2000\end{array}$ & - & $\begin{array}{l}\text { Salt Marsh } \\
\text { Schiermonnikoog, } \\
\text { The Netherlands }\end{array}$ & - & $\begin{array}{l}\text { This model describes changes in surface elevation } \\
\text { for long term salt marsh development using various } \\
\text { sea level rise scenarios. The model basis is that } \\
\text { changes in surface elevation depend on accretion } \\
\text { rate and shrinkage of the clay layer during the } \\
\text { summer. }\end{array}$ & - & $\begin{array}{l}\text { Surface } \\
\text { elevation }\end{array}$ \\
\hline
\end{tabular}


Table 2. Categorization of references by restoration technique, initial assessment, metrics, monitoring, or adaptive management. Relative sea level rates and location are reported if included. Abstracts for each reference can be found in Appendix B, in addition to general information references cited in the introduction, general sea level rise, salt marsh impacts, restoration strategy, and discussion sections.

\begin{tabular}{|c|c|c|c|c|c|c|c|c|c|c|c|c|c|c|c|}
\hline \multirow[b]{2}{*}{ Reference } & \multirow[b]{2}{*}{$\begin{array}{l}\text { Relative SLR } \\
\left(\mathrm{mm} \mathrm{y}^{-1}\right)\end{array}$} & \multirow[b]{2}{*}{$\begin{array}{l}\text { Location (U.S. State } \\
\text { or Country) }\end{array}$} & \multicolumn{9}{|c|}{ Restoration Techniques } & \multicolumn{4}{|c|}{ Measurements and Tools } \\
\hline & & & 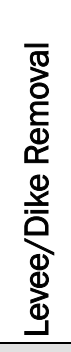 & 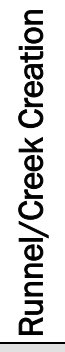 & 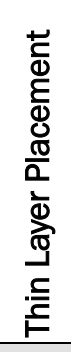 & 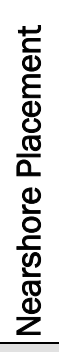 & 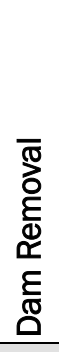 & 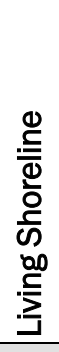 & 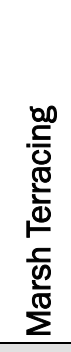 & 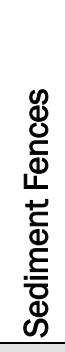 & 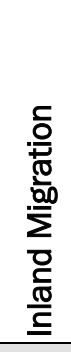 & 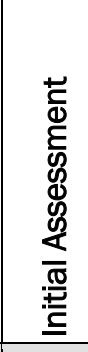 & $\begin{array}{l}\mathscr{O} \\
\frac{0}{5} \\
\sum\end{array}$ & 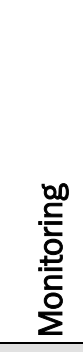 & 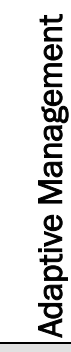 \\
\hline Adam 2009 & & & & & & & & & & & & & $x$ & $x$ & $X$ \\
\hline Armitage et al 2014 & & $\mathrm{TX}$ & & & & & & & $X$ & & & & $X$ & $X$ & \\
\hline Ayyub \& Kearney 2012 & & & & & & & & & & & & & & & $x$ \\
\hline Barber 2014 & 2 & WA & & & & & & & & & & & $x$ & $x$ & \\
\hline Bayard \& Elphick 2011 & & CT & & & & & & & & & & & $x$ & & \\
\hline Blum \& Roberts 2009 & & LA & & & & & & & & & & $x$ & & & \\
\hline Boere \& Taylor 2004 & & & & & & & & & & & & & & & $x$ \\
\hline Boesch et al 1994 & 10.4 & LA & & & & & & & & & & $X$ & & & \\
\hline Borde et al. 2004 & & Various & & & $x$ & & & & $x$ & & & $X$ & $X$ & $x$ & $X$ \\
\hline Boumans \& Day 1993 & & $\mathrm{LA}, \mathrm{GA}$ & & & & & & & & & & $x$ & & & \\
\hline Boumans et al. 1997 & $5-20$ & LA & & & & & & & & $x$ & & & & & \\
\hline Buchsbaum \& Wigand 2012 & & & & & & & & & & & & & $X$ & & $X$ \\
\hline Burkett \& Kusler 2000 & & & & & & & & & & & $X$ & & & & \\
\hline Cahoon 2006 & & FL, Hondorus & & & & & & & & & & & $x$ & & \\
\hline
\end{tabular}




\begin{tabular}{|c|c|c|c|c|c|c|c|c|c|c|c|c|c|c|c|}
\hline \multirow[b]{2}{*}{ Reference } & \multirow[b]{2}{*}{$\begin{array}{l}\text { Relative SLR } \\
\left(m m y^{-1}\right)\end{array}$} & \multirow[b]{2}{*}{$\begin{array}{l}\text { Location (U.S. State } \\
\text { or Country) }\end{array}$} & \multicolumn{9}{|c|}{ Restoration Techniques } & \multicolumn{4}{|c|}{ Measurements and Tools } \\
\hline & & & 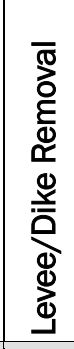 & 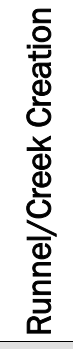 & 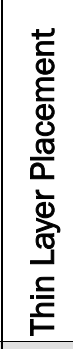 & 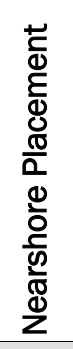 & 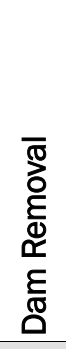 & 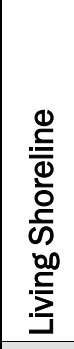 & 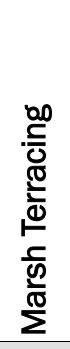 & 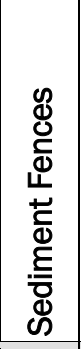 & 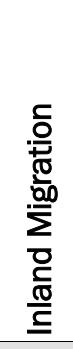 & 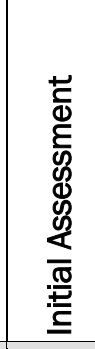 & $\begin{array}{l}\frac{3}{2} \\
\frac{0}{20}\end{array}$ & 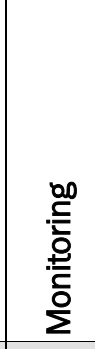 & 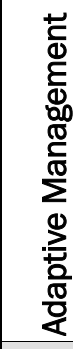 \\
\hline Cahoon \& Cowan 1987 & & LA & & & $x$ & & & & & & & & & $x$ & \\
\hline Cahoon \& Turner 1989 & & LA & & & & & & & & & & $x$ & & & \\
\hline Cahoon et al. 1995 & $13,2,2$ & LA, FL, NC & & & & & & & & & & $x$ & $x$ & & \\
\hline Cahoon et al. 2002a & & & & & & & & & & & & $x$ & & & \\
\hline Cahoon et al. 2002b & & & & & & & & & & & & $x$ & & & \\
\hline Clausen et al. 2013 & & Denmark & & & & & & & & & $x$ & & & & \\
\hline Convertino et al. 2011 & & $\mathrm{FL}$ & & & & & & & & & & & & & $x$ \\
\hline Cornu \& Sadro 2002 & & OR & & & $x$ & & & & & & & & & & \\
\hline Craft et al. 1999 & & NC & & & & & & & & & & & & $x$ & \\
\hline Craft et al. 2008 & & GA & & & & & & & & & $x$ & $x$ & & & \\
\hline Croft et al. 2006 & & NC & & & $x$ & & & & & & & & & & \\
\hline Currin et al. 2010 & & NC & & & & & & $x$ & & & & & & & \\
\hline Dale 2007 & & Australia & & $x$ & & & & & & & & & & & \\
\hline
\end{tabular}




\begin{tabular}{|c|c|c|c|c|c|c|c|c|c|c|c|c|c|c|c|}
\hline \multirow[b]{2}{*}{ Reference } & \multirow[b]{2}{*}{$\begin{array}{l}\text { Relative SLR } \\
\left(\mathrm{mm} \mathrm{y}^{-1}\right)\end{array}$} & \multirow[b]{2}{*}{$\begin{array}{l}\text { Location (U.S. State } \\
\text { or Country) }\end{array}$} & \multicolumn{9}{|c|}{ Restoration Techniques } & \multicolumn{4}{|c|}{ Measurements and Tools } \\
\hline & & & 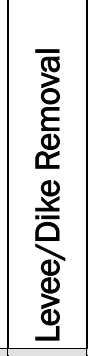 & 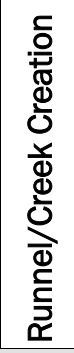 & 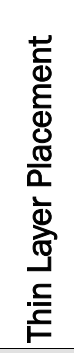 & 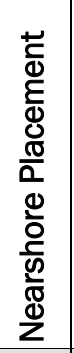 & 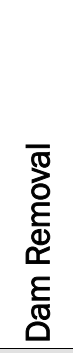 & 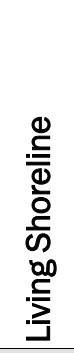 & 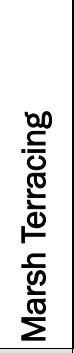 & 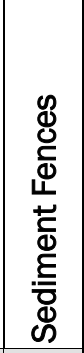 & 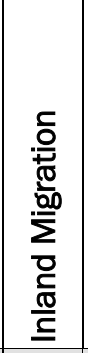 & 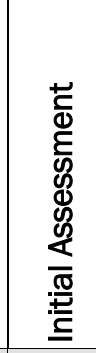 & $\frac{3}{3}$ & 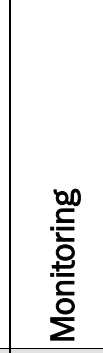 & 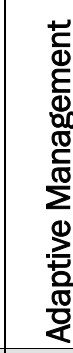 \\
\hline Day Templet 1989 & $11-13$ & LA & & & & & & & & & & $x$ & & & \\
\hline Day et al. 1995 & $>10$ & LA & & & & & & & & $x$ & & $x$ & & & \\
\hline Day et al. 1997 & & & & & & & & & & & & $x$ & & & \\
\hline Day et al. 2005 & $13-17$ & LA & $x$ & & & & & & & & & & & & \\
\hline Day et al. 2007 & 10 & LA & & & & & & & & & & & & & $x$ \\
\hline Day et al. 2016 & & & $x$ & & & & & & & & & & & & \\
\hline DeLaune et al. 1990 & & LA & & & $x$ & & & & & & & & & & \\
\hline Deng et al. 2008 & & China & & & $x$ & & & & & & & & & & \\
\hline DiGennaro et al. 2012 & & CA & & & & & & & & & & & & $x$ & $x$ \\
\hline Donnelly \& Bertness 2001 & 2.7 & $\mathrm{RI}$ & & & & & & & & & & $x$ & $x$ & $x$ & \\
\hline Eertman et al. 2002 & & The Netherlands & & $x$ & & & & & & & & & $x$ & $x$ & \\
\hline Elliott et al. 2007 & & & & & & & & & & & & & & $x$ & \\
\hline Erwin et al. 2004 & & MA, NJ, VA & & & & & & & & & & $x$ & & & \\
\hline
\end{tabular}




\begin{tabular}{|c|c|c|c|c|c|c|c|c|c|c|c|c|c|c|c|}
\hline \multirow[b]{2}{*}{ Reference } & \multirow[b]{2}{*}{$\begin{array}{l}\text { Relative SLR } \\
\left(m m y^{-1}\right)\end{array}$} & \multirow[b]{2}{*}{$\begin{array}{l}\text { Location (U.S. State } \\
\text { or Country) }\end{array}$} & \multicolumn{9}{|c|}{ Restoration Techniques } & \multicolumn{4}{|c|}{ Measurements and Tools } \\
\hline & & & 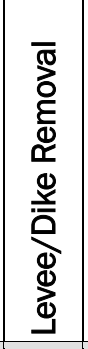 & 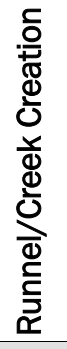 & 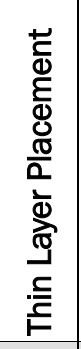 & 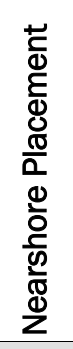 & 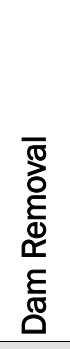 & 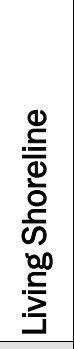 & 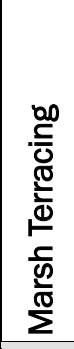 & 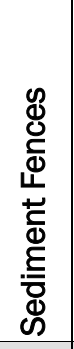 & 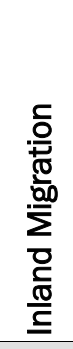 & 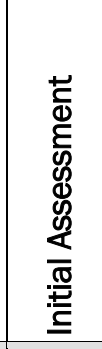 & 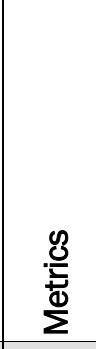 & 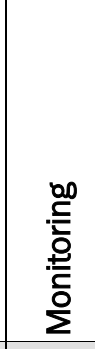 & 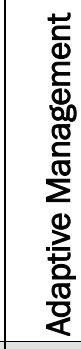 \\
\hline Ewel et al. 2001 & & & & & & & & & & & & & & $x$ & $x$ \\
\hline Fagherazzi et al. 2012 & & & & & & & & & & & & $x$ & & & \\
\hline Feagin \& Wu 2006 & & TX & & & & & & & $x$ & & & & $x$ & & \\
\hline Fischenich 2008 & & & & & & & & & & & & & & $x$ & $x$ \\
\hline FitzGerald et al. 2008 & & Various & & & & & & & & & $x$ & & & & \\
\hline Friedrichs \& Perry 2001 & & & & & & & & & & & & $x$ & & & \\
\hline Galbraith et al. 2002 & & WA, CA, TX & & & & & & & & & $x$ & & & & \\
\hline Ganju et al. 2015 & 3.48 & MD & & & & & & & & & & $x$ & & & \\
\hline Gedan et al. 2009 & & & & & & & & & & & $x$ & & & & \\
\hline Gesch 2009 & & NC & & & & & & & & & & $x$ & & & \\
\hline Glick et al. 2013 & & LA & & & & & & & & & $x$ & $\mathrm{x}$ & & $x$ & $x$ \\
\hline Gulf Coast n.d & & & & & & & & & & & & & $x$ & & \\
\hline Hackney 2000 & & & & & & & & & & & & & & $x$ & $x$ \\
\hline
\end{tabular}




\begin{tabular}{|c|c|c|c|c|c|c|c|c|c|c|c|c|c|c|c|}
\hline \multirow[b]{2}{*}{ Reference } & \multirow[b]{2}{*}{$\begin{array}{l}\text { Relative SLR } \\
\left(\mathrm{mm} \mathrm{y}^{-1}\right)\end{array}$} & \multirow[b]{2}{*}{$\begin{array}{l}\text { Location (U.S. State } \\
\text { or Country) }\end{array}$} & \multicolumn{9}{|c|}{ Restoration Techniques } & \multicolumn{4}{|c|}{ Measurements and Tools } \\
\hline & & & 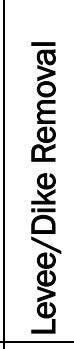 & 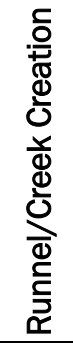 & 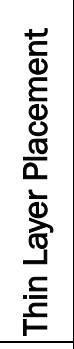 & 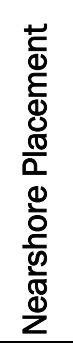 & 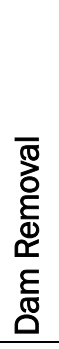 & 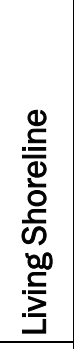 & 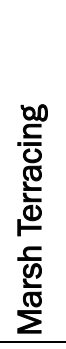 & 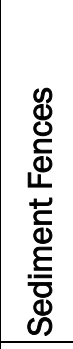 & 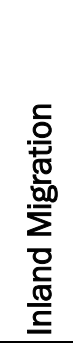 & 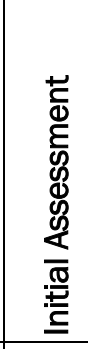 & 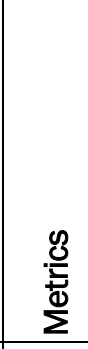 & 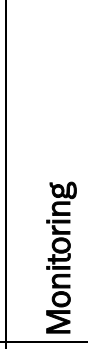 & 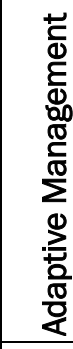 \\
\hline Haltiner et al. 1997 & & $\mathrm{CA}$ & & $x$ & & & & & & & & & $x$ & $x$ & \\
\hline Hartig et al. 2002 & 2.7 & NY & & & $x$ & & & & & & $x$ & $\mathrm{x}$ & & & \\
\hline Healey et al. 2007 & & $\mathrm{CA}$ & & & & & & & & & & & & & $x$ \\
\hline Heberger et al. 2009 & 2.01 & CA & & & & & & & & & & $x$ & & & \\
\hline Heilman et al. 2007 & & & & & & $x$ & & & & & & & & & \\
\hline Hughes 2004 & 1.5 & England & & & & & & & & & $x$ & & & & \\
\hline Kentula 2000 & & & & & & & & & & & & & $x$ & $x$ & $x$ \\
\hline Kirwan \& Murray 2007 & & & & & & & & & & & & $x$ & & & \\
\hline Konisky et al. 2006 & & $\begin{array}{l}\text { ME, NH, MA, Nova } \\
\text { Scotia }\end{array}$ & $\mathrm{x}$ & & & & & & & & & & $x$ & $x$ & \\
\hline Koo et al. 2011 & & Korea & & $x$ & & & & & & $x$ & & & & & \\
\hline La Peyre et al. 2009 & 3.6-17.7 & LA & & & & & & & & & & & & & $x$ \\
\hline Lewis 2000 & & $\mathrm{FL}$ & & & & & & & & & & & & $\mathrm{x}$ & $\mathrm{x}$ \\
\hline
\end{tabular}




\begin{tabular}{|c|c|c|c|c|c|c|c|c|c|c|c|c|c|c|c|}
\hline \multirow[b]{2}{*}{ Reference } & \multirow[b]{2}{*}{$\begin{array}{l}\text { Relative SLR } \\
\left(\mathrm{mm} \mathrm{y}^{-1}\right)\end{array}$} & \multirow[b]{2}{*}{$\begin{array}{l}\text { Location (U.S. State } \\
\text { or Country) }\end{array}$} & \multicolumn{9}{|c|}{ Restoration Techniques } & \multicolumn{4}{|c|}{ Measurements and Tools } \\
\hline & & & 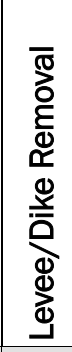 & 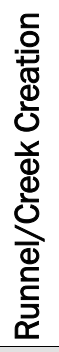 & 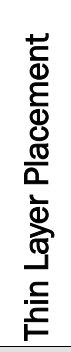 & 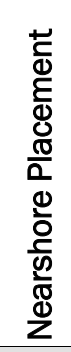 & 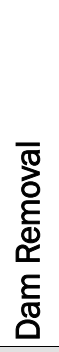 & 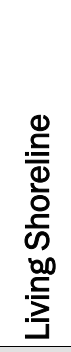 & 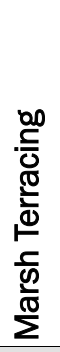 & 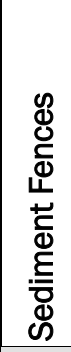 & 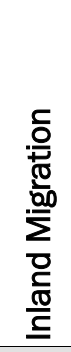 & 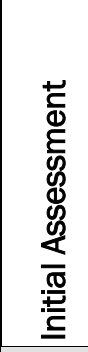 & 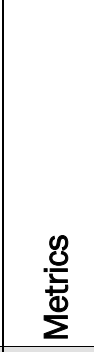 & 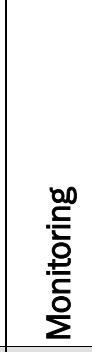 & 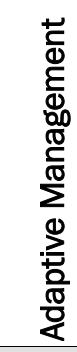 \\
\hline Lowe \& Bourgeois 2015 & & $\mathrm{CA}$ & & & & $x$ & & $x$ & & $x$ & $x$ & & & & \\
\hline MacBroom \& Schiff 2012 & & & & & & & & & & & & $X$ & & & \\
\hline Mariotti \& Fagherazzi 2013 & & & & & & & & & & & & $x$ & & & \\
\hline Martin et al. 2002 & $5-12$ & LA & & & & & & & & & & $x$ & & & \\
\hline Mendelssohn \& Kuhn 2003 & 3.6-17.7 & LA & & & $x$ & & & & & & & & & & \\
\hline Moorhead \& Brinson 1995 & & NC & & & & & & & & & $x$ & & & & \\
\hline Morris et al. 2002 & 3.4 & SC & & & & & & & & & & $x$ & & & \\
\hline Neckles et al. 2002 & & & & & & & & & & & & & $x$ & $x$ & $x$ \\
\hline Neckles et al. 2013 & & & & & & & & & & & & & & $x$ & \\
\hline Nicholls 2003 & & & & & & & & & & & & & & $x$ & $x$ \\
\hline NOAA 2015 & & & & & & & & $x$ & & & & & & & \\
\hline NPS 2004 & 3 & NY & & & & & & & & & & $X$ & & & \\
\hline NRC 1995 & & & & & & & & & & & & & & & $x$ \\
\hline NRC 2010 & & $\mathrm{CA}$ & & & & & & & & & & & & & $x$ \\
\hline NYC DEP 2007 & & NY & & & & & & & & & & & & & $x$ \\
\hline O'Neill 2015 & & NY & & & & & & & & & & $X$ & & & \\
\hline
\end{tabular}




\begin{tabular}{|c|c|c|c|c|c|c|c|c|c|c|c|c|c|c|c|}
\hline \multirow[b]{2}{*}{ Reference } & \multirow[b]{2}{*}{$\begin{array}{l}\text { Relative SLR } \\
\left(\mathrm{mm} \mathrm{y}^{-1}\right)\end{array}$} & \multirow[b]{2}{*}{$\begin{array}{l}\text { Location (U.S. State } \\
\text { or Country) }\end{array}$} & \multicolumn{9}{|c|}{ Restoration Techniques } & \multicolumn{4}{|c|}{ Measurements and Tools } \\
\hline & & & 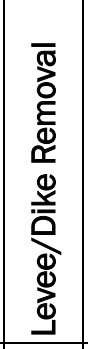 & 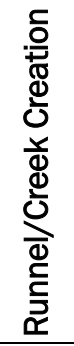 & 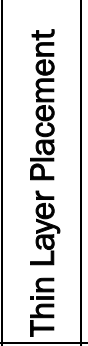 & 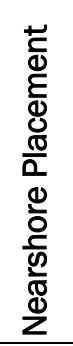 & 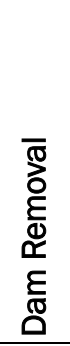 & 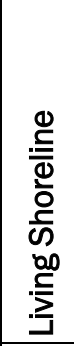 & 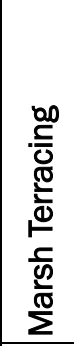 & 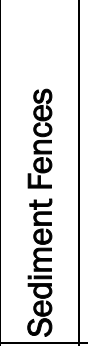 & 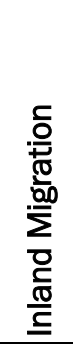 & 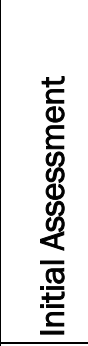 & 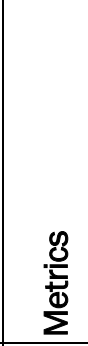 & 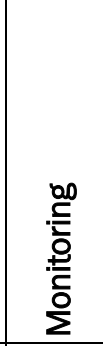 & 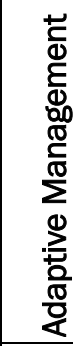 \\
\hline Orson et al. 1998 & 2.21 & $\mathrm{CT}, \mathrm{RI}$ & & & & & & & & & & $x$ & $x$ & & \\
\hline Palermo \& Dardeau 1994 & & & & & $x$ & & & & & & & & & $x$ & \\
\hline Pethick 1993 & $4-5$ & England & & & & & & & & & $x$ & & & & \\
\hline Pethick 2001 & 6 & England & & & & & & & & & $x$ & & & & \\
\hline Piazza et al. 2005 & & LA & & & & & & $x$ & & & & & & & \\
\hline Reed et al. 1999 & & England & & $x$ & & & & & & & & $x$ & & & \\
\hline Roman et al. 1997 & 2.4 & MA & & & & & & & & & & $x$ & $x$ & & \\
\hline Rozas \& Minello 2001 & & LA & & & & & & & $x$ & & & & & & \\
\hline Rozas et al. 2005 & & TX & & & & & & & $x$ & & & & & & \\
\hline Scarton et al. 2000 & & Italy & & & & & & & & $x$ & & & & $x$ & \\
\hline Schile et al. 2014 & & $\mathrm{CA}$ & & & & & & & & & & $x$ & & & \\
\hline Schrift et al. 2008 & 11.1 & LA & & & $x$ & & & & & & & & & & \\
\hline Short et al. 2000 & & & & & & & & & & & & & $x$ & & \\
\hline
\end{tabular}




\begin{tabular}{|c|c|c|c|c|c|c|c|c|c|c|c|c|c|c|c|}
\hline \multirow[b]{2}{*}{ Reference } & \multirow[b]{2}{*}{$\begin{array}{l}\text { Relative SLR } \\
\left(\mathrm{mm} \mathrm{y}^{-1}\right)\end{array}$} & \multirow[b]{2}{*}{$\begin{array}{l}\text { Location (U.S. State } \\
\text { or Country) }\end{array}$} & \multicolumn{9}{|c|}{ Restoration Techniques } & \multicolumn{4}{|c|}{ Measurements and Tools } \\
\hline & & & 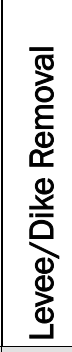 & 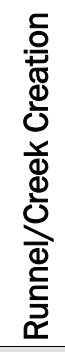 & 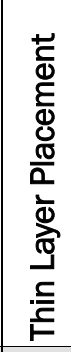 & 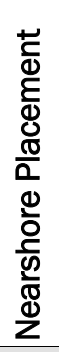 & 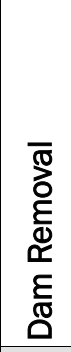 & 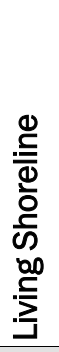 & 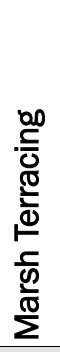 & 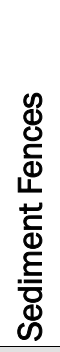 & 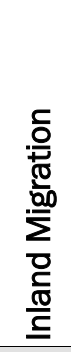 & 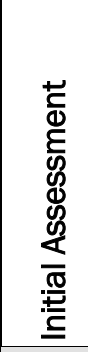 & 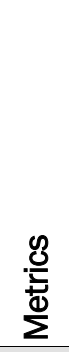 & 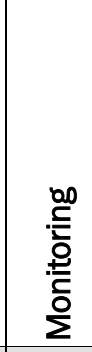 & 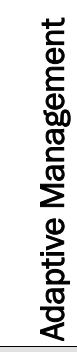 \\
\hline Simenstad et al. 2006 & & & & & & & $x$ & & & & & & & $x$ & $x$ \\
\hline Steyer et al. 2002 & & LA & & & & & & & & & & & & $x$ & \\
\hline Stralberg et al. 2011 & & $\mathrm{CA}$ & & & & & & & & & $x$ & $x$ & & & \\
\hline Teal \& Weinstein 2002 & & NJ & & $x$ & & & & & & & & & & & $x$ \\
\hline Teal \& Weishar 2005 & $2-3$ & NJ & $x$ & $x$ & & & & & & & & & & $x$ & $x$ \\
\hline Temmerman et al. 2004 & & The Netherlands & & & & & & & & & & $x$ & & & \\
\hline Thayer \& Kentula 2005 & & & & & & & & & & & & & & $x$ & $x$ \\
\hline Thom 1997 & & & & & & & & & & & & & & & $x$ \\
\hline Thom 2000 & & & & & & & & & & & & & & $x$ & $x$ \\
\hline Thom \& Wellman 1996 & & & & & & & & & & & & & & $x$ & \\
\hline Thorne et al. 2016 & & & & & & & & & & & & $x$ & & & \\
\hline Titus 1988 & & & & & $x$ & & & & & & & & & & \\
\hline Tobias et al. 2010 & & LA & & & & & & & & & & $x$ & & & \\
\hline Turner \& Cahoon 1987 & & TX, LA, MS & & & & & & & & & & $x$ & & & \\
\hline Twohig \& Stolt 2011 & & RI, MA & & & & & & & & & & $x$ & & & \\
\hline US DOI 2015 & & US Northeast & & & & & & & & & & & & $x$ & \\
\hline
\end{tabular}




\begin{tabular}{|c|c|c|c|c|c|c|c|c|c|c|c|c|c|c|c|}
\hline \multirow[b]{2}{*}{ Reference } & \multirow[b]{2}{*}{$\begin{array}{l}\text { Relative SLR } \\
\left(m m y^{-1}\right)\end{array}$} & \multirow[b]{2}{*}{$\begin{array}{l}\text { Location (U.S. State } \\
\text { or Country) }\end{array}$} & \multicolumn{9}{|c|}{ Restoration Techniques } & \multicolumn{4}{|c|}{ Measurements and Tools } \\
\hline & & & 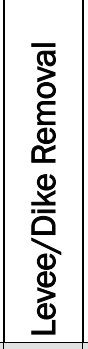 & 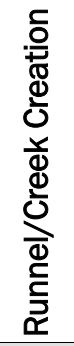 & 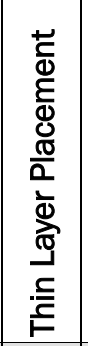 & 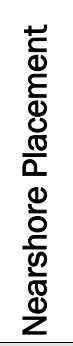 & 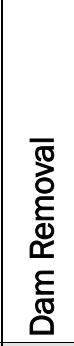 & 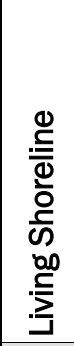 & 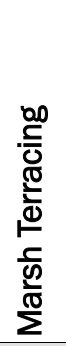 & 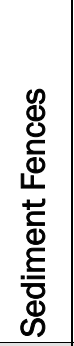 & 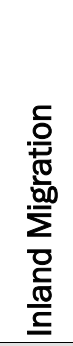 & 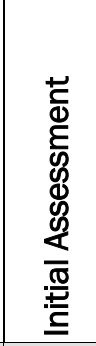 & $\frac{3}{2}$ & 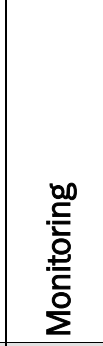 & 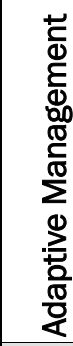 \\
\hline US FWS $2014 a$ & & $\mathrm{RI}$ & & & & & & & & & & $x$ & & $x$ & $x$ \\
\hline US FWS 2014b & & $\mathrm{CA}$ & & & & & & & & & & $x$ & & $x$ & \\
\hline US FWS 2014c & & $\mathrm{CA}$ & & & & & & & & & & & & & $x$ \\
\hline USACE 2014 & & & & & & & & & & & & & & & $x$ \\
\hline \multicolumn{16}{|l|}{ USACE 2015} \\
\hline Warren et al. 2002 & & CT & $x$ & & & & & & & & & & & & $x$ \\
\hline WRDA 2007 & & & & & & & & & & & & & & $x$ & $x$ \\
\hline Webb et al. 2013 & & & & & & & & & & & & $x$ & & & \\
\hline Weinstein et al. 2001 & & NJ & $x$ & $x$ & & & & & & & & $x$ & $x$ & $x$ & $x$ \\
\hline Weishar et al. 2005 & & NJ & & $x$ & & & & & & & & & & & \\
\hline Wigand et al. 2015 & & CT & & $x$ & $x$ & & $x$ & $x$ & & & $x$ & $x$ & $x$ & $x$ & $x$ \\
\hline Wilber 1993 & & Various & & & $x$ & & & & & & & & & $x$ & \\
\hline Williams \& Zedler 1999 & & $\mathrm{CA}$ & & & & & & & & & & & $x$ & & \\
\hline
\end{tabular}




\begin{tabular}{|c|c|c|c|c|c|c|c|c|c|c|c|c|c|c|c|}
\hline \multirow[b]{2}{*}{ Reference } & \multirow[b]{2}{*}{$\begin{array}{l}\text { Relative SLR } \\
\left(\mathrm{mm} \mathrm{y}^{-1}\right)\end{array}$} & \multirow[b]{2}{*}{$\begin{array}{l}\text { Location (U.S. State } \\
\text { or Country) }\end{array}$} & \multicolumn{9}{|c|}{ Restoration Techniques } & \multicolumn{4}{|c|}{ Measurements and Tools } \\
\hline & & & 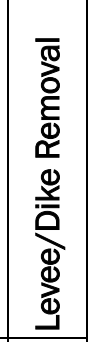 & 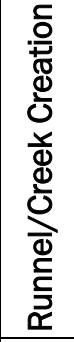 & 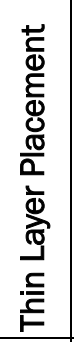 & 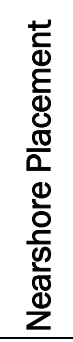 & 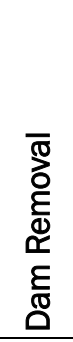 & 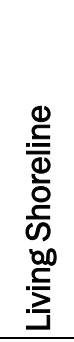 & 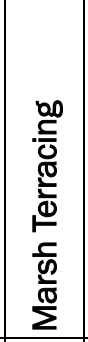 & 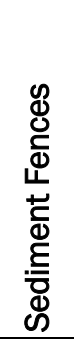 & 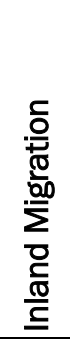 & 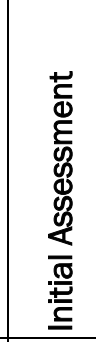 & $\frac{\mathscr{3}}{2}$ & 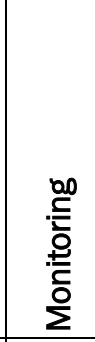 & 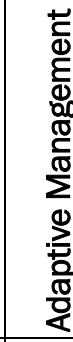 \\
\hline Willows \& Connell 2003 & & United Kingdom & & & & & & & & & & & & & $x$ \\
\hline Wilson \& Prickett 1998 & & FL, LA & & & & $x$ & & & & & & & & & \\
\hline Wu et al. 2015 & $2.03-2.54$ & MS & & & & & & & & & & $x$ & & & \\
\hline Zedler 1996 & & $\mathrm{CA}$ & & & & & & & & & & & & $x$ & \\
\hline Zedler 2000 & & & & $x$ & & & & & & & & & & $x$ & \\
\hline
\end{tabular}


Figure 1. Linking stressors, restoration strategies, and salt marsh response to restoration strategies (modified from Allen [2000]). SOM, soil organic matter.

\begin{tabular}{|c|c|c|c|c|}
\hline Stressors & & $\begin{array}{l}\text { Environmental Change } \\
\quad \text { (Eustatic SLR) }\end{array}$ & $\begin{array}{c}\text { Subsidence } \\
\text { (Compaction, dewatering, } \\
\text { extraction, SOM oxidation) }\end{array}$ & \\
\hline \multirow[t]{2}{*}{$\begin{array}{l}\text { Restoration } \\
\text { Strategies }\end{array}$} & $\begin{array}{c}\text { Hydrology } \\
\text { (Inundation, frequency) }\end{array}$ & $\begin{array}{l}\text { Sediment Supply } \\
\text { (Concentration) }\end{array}$ & $\begin{array}{l}\text { Vertical \& Horizontal Accretion } \\
\text { (wave, tidal energy) }\end{array}$ & Landward Migration \\
\hline & $\begin{array}{l}\text { - Engineer creeks/runnels } \\
\text { - Breach/remove dikes }\end{array}$ & $\begin{array}{l}\text { - Thin layer placement } \\
\text { - Nearshore placement } \\
\text { Remove upstream dams }\end{array}$ & $\begin{array}{l}\text { - } \quad \text { Living Shoreline } \\
\text { - } \quad \text { Sediment fencing }\end{array}$ & $\begin{array}{l}\text { Prioritizing areas for } \\
\text { land preservation or } \\
\text { marsh restoration }\end{array}$ \\
\hline Response & \multicolumn{4}{|c|}{$\begin{array}{l}\text { Optimum elevation and duration of tidal flooding increases } \\
\text { primary productivity }\end{array}$} \\
\hline
\end{tabular}




\section{Appendix A: List of Keywords Searched with Sea Level Rise}

The list of keywords that were searched in conjunction with sea-level rise is provided below. These keywords were searched between January to December 2016 in Google Scholar and the U.S. Army Engineer Research and Development Center Library. Additional papers and reference materials were obtained by reaching out to professionals in these fields and engaging in personal communication with professionals currently working on restoration strategies described in the text.

\begin{tabular}{|ccc|}
\hline Adaptive management & Leading edge erosion & Sediment deposition \\
Coastal & Levee breach & Sediment fences \\
Dike breach & Levee removal & Sediment placement \\
Dike removal & Living shoreline & Shorebirds \\
Dredged material & Marsh restoration & Southern United States \\
Dredged material placement & Marsh terracing & Storm surge \\
East coast & Monitoring & Tide gate \\
Ecological impacts & Nearshore placement & Tidal marsh \\
Ecosystem restoration & Northeast & Thin layer augmentation \\
Flooded marsh & Northwest & Thin layer deposition \\
Gulf Coast & Runnels & Thin layer placement \\
Inland migration & Restoration & United States \\
Impacts & Salt marsh & Waterfowl \\
& Salt marsh channels & West coast \\
\hline
\end{tabular}




\section{Appendix B: List of Abstracts Related to Salt Marsh Restoration}

Presented here is a complete list of abstracts related to salt marsh restoration and sea level rise collected during this literature review. Abstracts are listed alphabetically under each category identified in Table 2. Abstracts may appear in multiple categories if more than one category was identified in the article. Included in the additional references category are references with general information pertaining to salt marsh ecology, salt marsh restoration, or sea level rise. References are current up to December 2016.

\section{Levee/Dike Breach or Removal}

Day, J. W., Jr., J. Barras, E. Clairain, J. Johnston, D. Justic, G. P. Kemp, J. Y. Ko, R. Lane, W. J. Mitsch, G. Steyer, P. Templet, and A. YanezArancibia. 2005. "Implications of Global Climatic Change and Energy Cost and Availability for the Restoration of the Mississippi Delta." Ecological Engineering 24: 253-265.

https://doi.org/10.1016/i.ecoleng.2004.11.015

Day, J. W., R. R. Lane, C. F. D’Elia, A. R. H. Wiegman, J. S. Rutherford, G. P. Shaffer, C. G. Brantley, and G. P. Kemp. 2016. "Large Infrequently Operated River Diversions for Mississippi Delta Restoration.” Estuarine, Coastal and Shelf Science 183: 292-303. https://doi.org/10.1016/i.ecss.2016.05.001

Konisky, R. A., D. M. Burdick, M. Dionne, and H. A. Neckles. 2006. “A Regional Assessment of Salt Marsh Restoration and Monitoring in the Gulf of Maine." Restoration Ecology 14: 516-525. https://doi.org/10.1111/j.1526-100X.2006.00163.x

Warren, R. S., P. E. Fell, R. Rozsa, A. H. Brawley, A. C. Orsted, E. T. Olson, V. Swamy, and W. A. Niering. 2002. "Salt Marsh Restoration in Connecticut: 20 Years of Science and Management." Restoration Ecology 10: 497-513. https://doi.org/10.1046/j.1526-100X.2002.01031.x 
Weinstein, M. P., J. M. Teal, J. H. Balletto, and K. A. Strait. 2001. "Restoration Principles Emerging from One of the World's Largest Tidal Marsh Restoration Projects.” Wetlands Ecology and Management 9: 387-407.

https://doi.org/10.1023/A\%3A1012058713910

Zedler, J. B., and S. Kercher. 2005. "Wetland Resources: Status, Trends, Ecosystem Services, and Restorability." Annual Review of Environment and Resources 30: 39-74.

https://doi.org/10.1146/annurev.energy.30.050504.144248

\section{Runnel/Creek Creation}

Dale, P. E. R. 2007. "Assessing Impacts of Habitat Modification on a Subtropical Salt Marsh: 20 Years of Monitoring." Wetlands Ecology and Management 16: 77-87. https://doi.org/10.1007/s11273-007-9058-2

Eertman, R. H. M., B. A. Kornman, E. Stikvoort, and H. Verbeek. 2002. "Restoration of the Sieperda Tidal Marsh in the Scheldt Estuary, The Netherlands." Restoration Ecology 10: 438-449.

https://doi.org/10.1046/j.1526-100X.2002.01034.X

Haltiner, J., J. B. Zedler, G. D. Williams, and J. C. Callaway. 1997. "Influence of Physical Processes on the Design, Functioning, and Evolution of Restored Tidal Wetlands in California." Wetlands Ecology and Management 4: 73-91.

https://doi.org/10.1007/BF01876230

Koo, B. J., J. G. Je, and H. J. Woo. 2011. "Experimental Restoration of a Salt Marsh with Some Comments on Ecological Restoration of Coastal Vegetated Ecosystems in Korea." Ocean Science Journal 46: 47-53.

https://doi.org/10.1007/s12601-011-0004-0 
Reed, D. J., T. Spencer, A. L. Murray, J. R. French, and L. Leonard. 1999. "Marsh Surface Sediment Deposition and the Role of Tidal Creeks: Implications for Created and Managed Coastal Marshes." Journal of Coastal Conservation 5: 81-90.

https://doi.org/10.1007/BF02802742

Teal, J. M., and M. P. Weinstein. 2002. "Ecological Engineering, Design, and Construction Considerations for Marsh Restorations in Delaware Bay, USA.” Ecological Engineering 18: 607-618. https://doi.org/10.1016/S0925-8574(02)00023-X

Teal, J. M., and L. Weishar. 2005. "Ecological Engineering, Adaptive Management, and Restoration Management in Delaware Bay Salt Marsh Restoration." Ecological Engineering 25: 304-314. https://doi.org/10.1016/j.ecoleng.2005.04.009

Weinstein, M. P., J. M. Teal, J. H. Balletto, and K. A. Strait. 2001. "Restoration Principles Emerging from One of the World's Largest Tidal Marsh Restoration Projects." Wetlands Ecology and Management 9: 387-407. https://doi.org/10.1023/A:1012058713910

Weishar, L. L, J. M. Teal, and R. Hinkle. 2005. "Designing Large-Scale Wetland Restoration for Delaware Bay.” Ecological Engineering 25: 231-239.

https://doi.org/10.1016/j.ecoleng.2005.04.012

Wigand, C., T. Ardito, C. Chaffee, W. Ferguson, S. Paton, K. Raposa, C. Vandemoer, and E. Watson. 2015. "A Climate Change Adaptation Strategy for Management of Coastal Marsh Systems.” Estuaries and Coasts 40(3): 682-693. https://doi.org/10.1007/s12237-015-0003-y

Zedler, J. B. 2000. "Progress in Wetland Restoration Ecology." Tree 15: 402-407. https://doi.org/10.1016/S0169-5347(00)01959-5 
Zedler, J. B., and S. Kercher. 2005. "Wetland Resources: Status, Trends, Ecosystem Services, and Restorability." Annual Review of Environment and Resources 30: 39-74. https://doi.org/10.1146/annurev.energy.30.050504.144248

\section{Thin Layer Placement}

Borde, A. B., L.K. O'Rourke, R. M. Thom, G. W. Williams, and H. L. Diefenderfer. 2004. National Review of Innovative and Successful Coastal Habitat Restoration. Prepared for National Oceanic and Atmospheric Administration Coastal Services Center. Battelle Memorial Institute, Contract 44188. Sequim, WA.

"Coastal habitat restoration is a burgeoning science, with numerous organizations participating in an increasing number of projects and programs across the country. Examples of innovative and successful components of these efforts are summarized in this review. The information on projects and programs was collected through expert interviews and through a nationwide review of scientific literature, restoration plans, and Internet sources. The examples provided cover many coastal habitat types from the four coasts of the United States. The review provides information on restoration research and the innovative and successful components of funding, partnerships, planning, restoration methods and techniques, monitoring, adaptive management, information dissemination, and community involvement. The lessons learned from the experiences of the many sources noted in this review are summarized at the end of the paper. Through this work we hope to contribute toward the success of future restoration efforts." https://repository.library.noaa.gov/view/noaa/2555

Cahoon, D. R., and J. H. Cowan, Jr. 1987. Spray Disposal of Dredged Material in Coastal Louisiana: Habitat Impacts and Regulatory Policy Implications. Louisiana Sea Grant College Program, Louisiana State University, Baton Rouge, LA.

"Dredging canals for navigation, pipelines, and access to drilling sites is a common activity in the Louisiana coastal zone. Traditionally, the spoil dredged during construction is banked alongside the canal at elevations significantly higher than the 
surrounding marsh (Cahoon et al. 1986). In Louisiana marshes, spoil banks accommodate upland vegetation that was not present before the canals were dredged and often provide habitat for birds, waterfowl, and wildlife not found previously within the coastal area (Olson 1975; Bettinger and Hamilton 1985). It has been suggested that canals and their associated spoil banks contribute to land loss in the Louisiana coastal zone by (1) directly converting marsh habitat to open water and upland (spoil bank) habitat; and (2) altering the local hydrologic regime, i.e., sheetflow over the marsh, subsurface flow, and saltwater intrusion (Turner 1985; Swenson and Turner 1987). The cumulative effects of canals and their spoil banks on ecosystem hydrology and wetland loss may also be important (Turner 1985; Cowan et al. 1986). Minimizing the impacts associated with spoil banks is a major concern of state and federal agencies regulating development in wetlands. Current regulatory practices of the Louisiana Department of Natural Resources' Coastal Management Division (LDNR/CMD) require that access canals must be plugged and spoil either gapped or backfilled when wells are abandoned. The regulatory requirements of federal agencies such as the U.S. Fish and Wildlife Service (USFWS), the National Marine Fisheries Service (NMFS), and the U.S. Army Corps of Engineers (COE) are similar in intent and scope. Therefore, any new technology that minimizes spoil bank impacts would be of great interest to the regulatory agencies as a resource management tool. Industry, which must pay for mitigating the impacts of current dredging methods, also would be interested in any technology that speeds up the permitting process and reduces mitigation expenses, provided that it is not prohibitively expensive."

https://eos.ucs.uri.edu/seagrant_Linked_Documents/Isu/Isut87006.pdf

Cornu, C. E., and S. Sadro. 2002. "Physical and Functional Responses to Experimental Marsh Surface Elevation Manipulation in Coos Bay's South Slough." Restoration Ecology 10: 474-486.

https://doi.org/10.1046/j.1526-100X.2002.01035.x 
Croft, A. L., L. A. Leonard, T. D. Alphin, L. B. Cahoon, and M. H. Posey. 2006. "The Effects of Thin Layer Sand Renourishment on Tidal Marsh Processes: Masonboro Island, North Carolina." Estuaries and Coasts 29: 737-750. https://doi.org/10.1007/BF02786525

DeLaune, R. D., S. R. Pezeshki, J. H. Pardue, J. H. Whitcomb, and W. H. Patrick, Jr. 1990. "Some Influences of Sediment Addition to a Deteriorating Salt Marsh in the Mississippi River Deltaic Plain: A Pilot Study." Journal of Coastal Research 6: 181-188.

https://www.jstor.org/stable/4297655

Deng, Z., S. An, C. Zhao, L. Chen, C. Zhou, Y. Zhi, and H. Li. 2008. "Sediment Burial Stimulates the Growth and Propagule Production of Spartina alterniflora Loisel." Estuarine, Coastal and Shelf Science 76: 818-826. https://doi.org/10.1016/j.ecss.2007.08.008

Ford, M. A., D. R. Cahoon, and J. C. Lynch. 1999. "Restoring Marsh Elevation in a Rapidly Subsiding Salt Marsh by Thin-Layer Deposition of Dredged Material." Ecological Engineering 12: 189205 .

https://doi.org/10.1016/S0925-8574(98)00061-5

Hartig, E. K., V. Gornitz, A. Kolker, F. Mushacke, and D. Fallon. 2002. "Anthropogenic and Climate-Change Impacts on Salt Marshes of Jamaica Bay, New York City.” Wetlands 22: 71-89. https://doi.org/10.1672/0277-5212(2002)022[0071:AACCI0]2.0.C0;2

Mendelssohn, I. A., and N. L. Kuhn. 2003. "Sediment Subsidy: Effects on Soil-Plant Responses in a Rapidly Submerging Coastal Salt Marsh.” Ecological Engineering 21: 115-128.

https://doi.org/10.1016/j.ecoleng.2003.09.006

Palermo, M. R., and E. A. Dardeau, Jr. 1994. "Guidance for Wetland Restoration with Dredged Material.” Dredging ‘94. Vicksburg, MS: U.S. Army Engineer Waterways Experiment Station. 
"Wetlands can be restored or created using dredged material that currently presents a disposal challenge. At several US Army Corps of Engineers sites around the country, dredged material has been used to create new wetlands and to restore degraded wetlands to a more productive state. Varying levels of restoration or creation -success $\bullet$ have been achieved for these projects due in part to a lack of definitive guidelines for site preparation, structure selection and siting, placement of dredged material, vegetation selection and installation and operation and maintenance. The US Army Engineer Waterways Experiment Station (WES) is in the process of developing a handbook for wetland restoration and establishment. The handbook encapsulates the experience gained under the Wetlands Research Program. The Dredged Material Research Program, and other research conducted at the WES. This paper summarizes the design sequence and design guidelines presented within the handbook and other general considerations that relate to the restoration and creation of wetlands using dredged material."

Ray, G. L. 2007. Thin Layer Disposal of Dredged Material on Marshes: A Review of the Technical and Scientific Literature. ERDC/EL TN07-1. Vicksburg, MS: U.S. Army Engineer Research and Development Center.

"Coastal wetlands in many areas are deteriorating due, in part, to sediment depletion, subsidence, and sea level rise. The purpose of this technical note is to review and synthesize the available scientific and technical literature concerning thin layer placement of dredged materials in wetlands to ameliorate these effects."

http://hdl.handle.net/11681/3795

Schrift, A. M., I. A. Mendelssohn, and M. D. Materne. 2008. "Salt Marsh Restoration with Sediment-Slurry Amendments Following a Drought-Induced Large Scale Disturbance.” Wetlands 28: 10711085 .

https://doi.org/10.1672/07-78.1 
Titus, J. G. 1988. "Alternatives for Protecting Coastal Wetlands from the Rising Sea." Greenhouse Effect, Sea-Level Rise and Coastal Wetlands, 151-152. EPA 230-05-86-013. Washington, DC: U.S. Environmental Protection Agency.

"Recognizing the numerous benefits and values accrued to society from wetlands, there are several options available for minimizing potential future losses of wetlands from predicted sea level rise. These protection alternatives focus on methods available to local planners and decision-makers who can influence regional efforts to ameliorate the impacts on coastal resources associated with sea level rise."

http://papers.risingsea.net/federal_reports/sea-level-rise-and-wetlands-chap5.pdf

Wigand, C., T. Ardito, C. Chaffee, W. Ferguson, S. Paton, K. Raposa, C. Vandemoer, and E. Watson. 2015. "A Climate Change Adaptation Strategy for Management of Coastal Marsh Systems." Estuaries and Coasts 4O(3): 682-693.

https://doi.org/10.1007/s12237-015-0003-y

Wilber, P. 1993. Environmental Effects of Dredging Technical Notes: Managing Dredged Material via Thin-Layer Disposal in Coastal Marshes. EEDP-01-32. Vicksburg, MS: U.S. Army Engineer Research and Development Center.

"This technical note describes how dredged material can be successfully managed in an environmentally sound manner in marshes by placing it in layers of 5 to $15 \mathrm{~cm}$. (Unless otherwise indicated, all layer thicknesses indicated in this report refer to material that has undergone post-disposal consolidation.) Environmental studies of this process and of the regulatory history of thin-layer disposal in marshes are summarized. General planning and monitoring considerations are described, including descriptions of the types of equipment used to place dredged material in thin layers in marshes.

This note complements Environmental Effects of Dredging Information Exchange Bulletins, Volumes D-92-1, D-92-3, and D92-5, which describe case histories of thin-layer disposal, and an upcoming Environmental Effects of Dredging technical note, which 
will provide additional detail on engineering aspects of managing dredged material by thin-layer disposal. Together, these documents provide guidance for the planning, execution, and monitoring of thin-layer disposal in marshes."

http://hdl.handle.net/11681/8802

\section{Nearshore Placement}

Heilman, D. J., J. T. Darnell, and M. C. Perry. 2007. "Sediment Analysis for Habitat Restoration: Adaption of Open-Coast Beach Nourishment Principles." Proceedings of the Sixth International Symposium on Coastal Engineering and Science of Coastal Sediment Process, 1-9.

https://doi.org/10.1061/40926(239)59

Lowe, J., and J. Bourgeois. 2015. "Science Foundation Chapter 2 - The Projected Evolution of Baylands Habitats." In Baylands Ecosystem Habitat Goals Science Update 2015. Prepared by the San Francisco Bay Area Wetlands Ecosystem Goals Project. Oakland, CA: California State Coastal Conservancy.

"The projected drivers for change, in particular climate and sea level, will likely affect the evolution of baylands habitats over the next century. We understand the baylands to be evolving in three major directions; vertical accretion based on sediment supply and organic accumulation, landward migration (also called transgression) based on availability of terrestrial transition zone space, and lateral movement of the bayward marsh edge. Because tidal marshes are highly sensitive to elevation, their sustainability in San Francisco Bay (and elsewhere) will depend on the balance between sea-level rise and marsh sediment accretion (Michener et al. 1997, Morris et al. 2002). As discussed in Science Foundation Chapter 1, the existing marshes have a range of elevations covering low to high marsh; the higher parts of the marshes give substantial "elevation capital" (Cahoon and Guntenspergen 2010), i.e., they have elevation to lose before they convert to unvegetated mudflat.

This raises two key questions: firstly, how are baylands habitats (e.g., marshes, mudflats and managed ponds) likely to evolve over the next century? To answer this question we need to understand the present evolution and then make projections of future 
evolution. Once we understand the future evolution we can address the second key question: what management actions can we take to guide the evolution of baylands habitat in the short- and long-term? The decision about when to implement each of these measures will depend on the rate of sea-level rise, and in particular when certain threshold elevations will be crossed that trigger the need for intervention."

https://baylandsgoals.org/wp-content/uploads/2015/10/BEHGU_SFC2.pdf

Williams, G. L., and T. L. Prickett. 1998. Planning Considerations for Nearshore Placement of Mixed Dredged Sediments. Technical Note DOER-N3. Vicksburg, MS: U.S. Army Engineers Waterways Experiment Station.

"Dredging planning and management decisions are based on a combination of engineering and economic factors tempered by environmental considerations. The purpose of this technical note is to address primary considerations (although not all-inclusive) for planning and managing near-shore placement of mixed sediment from dredging projects."

http://hdl.handle.net/11681/8645

\section{Dam Removal}

Simenstad, C., D. Reed, and M. Ford. 2006. "When is Restoration Not? Incorporating Landscape-Scale Processes to Restore SelfSustaining Ecosystems in Coastal Wetland Restoration." Ecological Engineering 26: 27-39.

https://doi.org/10.1016/j.ecoleng.2005.09.007

Wigand, C., T. Ardito, C. Chaffee, W. Ferguson, S. Paton, K. Raposa, C. Vandemoer, and E. Watson. 2015. "A Climate Change Adaptation Strategy for Management of Coastal Marsh Systems." Estuaries and Coasts 40(3): 682-693. https://doi.org/10.1007/s12237-015-0003-y

Zhao, Q., J. Bai, L. Huang, B. Gu, Q. Lu, and Z. Gao. 2016. "A Review of Methodologies and Success Indicators for Coastal Wetland Restoration." Ecological Indicators 60: 442-452. 


\section{Living Shoreline}

Currin, C. A., W. S. Chappell, and A. Deaton. 2010. "Developing Alternative Shoreline Armoring Strategies: The Living Shoreline Approach in North Carolina." In Puget Sound Shorelines and the Impacts of Armoring-Proceedings of a State of the Science Workshop, edited by H. Shipman, M. N. Dethier, G. Gelfenbaum, K. L. Fresh, and R. S. Dinicola, 91-102, May 2009. U.S. Geological Survey Scientific Investigations Report 2010-5254. Washington, DC: U.S. Department of the Interior.

"This paper reviews the scientific data on the ecosystem services provided by shoreline habitats, the evidence for adverse impacts from bulk-heading on those habitats and services, and describes alternative approaches to shoreline stabilization, which minimize adverse impacts to the shoreline ecosystem. Alternative shoreline stabilization structures that incorporate natural habitats, also known as living shorelines, have been popularized by environmental groups and state regulatory agencies in the midAtlantic. Recent data on living shoreline projects in North Carolina that include a stone sill demonstrate that the sills increase sedimentation rates, that after 3 years marshes behind the sills have slightly reduced biomass, and that the living shoreline projects exhibit similar rates of fishery utilization as nearby natural fringing marshes. Although the current emphasis on shoreline armoring in Puget Sound is on steeper, higher-energy shorelines, armoring of lower-energy shorelines may become an issue in the future with expansion of residential development and projected rates of sea level rise. The implementation of regulatory policy on estuarine shoreline stabilization in North Carolina and elsewhere is presented. The regulatory and public education issues experienced in North Carolina, which have made changes in estuarine shoreline stabilization policy difficult, may inform efforts to adopt a sustainable shoreline armoring strategy in Puget Sound. A necessary foundation for regulatory change in shoreline armoring policy, and public support for that change, is rigorous scientific assessment of the variety of services that natural shoreline habitats provide both to the ecosystem and to coastal communities, and evidence demonstrating that shoreline armoring can adversely impact the provision of those services." 
Lowe, J., and J. Bourgeois. 2015. "Science Foundation Chapter 2 - The Projected Evolution of Baylands Habitats.” In Baylands Ecosystem Habitat Goals Science Update 2015. Prepared by the San Francisco Bay Area Wetlands Ecosystem Goals Project. Oakland, CA: California State Coastal Conservancy.

"The projected drivers for change, in particular climate and sea level, will likely affect the evolution of baylands habitats over the next century. We understand the baylands to be evolving in three major directions; vertical accretion based on sediment supply and organic accumulation, landward migration (also called transgression) based on availability of terrestrial transition zone space, and lateral movement of the bayward marsh edge. Because tidal marshes are highly sensitive to elevation, their sustainability in San Francisco Bay (and elsewhere) will depend on the balance between sea-level rise and marsh sediment accretion (Michener et al. 1997, Morris et al. 2002). As discussed in Science Foundation Chapter 1, the existing marshes have a range of elevations covering low to high marsh; the higher parts of the marshes give substantial "elevation capital" (Cahoon and Guntenspergen 2010), i.e., they have elevation to lose before they convert to unvegetated mudflat.

This raises two key questions: firstly, how are baylands habitats (e.g., marshes, mudflats and managed ponds) likely to evolve over the next century? To answer this question we need to understand the present evolution and then make projections of future evolution. Once we understand the future evolution we can address the second key question: what management actions can we take to guide the evolution of baylands habitat in the short- and long-term? The decision about when to implement each of these measures will depend on the rate of sea-level rise, and in particular when certain threshold elevations will be crossed that trigger the need for intervention."

https://baylandsgoals.org/wp-content/uploads/2015/10/BEHGU_SFC2.pdf

National Oceanic and Atmospheric Administration (NOAA). 2015. Guidance for Considering the Use of Living Shorelines. https://www.habitatblueprint.noaa.gov/wp-content/uploads/2018/01/NOAA-Guidance-forConsidering-the-Use-of-Living-Shorelines_2015.pdf.

"Coastal communities face constant challenges from shoreline erosion. Although erosion is a natural coastal process, many valuable 
resources border the nation's coastline. Shorelines need protection from damage caused by intense storms, wave erosion, and sea level rise. Shoreline stabilization does not need to create a barrier between land and water, as happens with hard shoreline stabilization structures like seawalls and bulkheads. New stabilization options, like living shorelines, are gaining attention as an alternative to traditional shoreline stabilization techniques. Living shorelines can reduce damage and erosion while simultaneously providing ecosystem services to society, including food production, nutrient and sediment removal, and water quality improvement. Living shoreline is a broad term that encompasses a range of shoreline stabilization techniques along estuarine coasts, bays, sheltered coastlines, and tributaries. A living shoreline has a footprint that is made up mostly of native material. It incorporates vegetation or other living, natural "soft" elements alone or in combination with some type of harder shoreline structure (e.g., oyster reefs or rock sills) for added stability. Living shorelines maintain continuity of the natural land-water interface and reduce erosion while providing habitat value and enhancing coastal resilience. NOAA encourages the use of living shorelines as a shoreline stabilization technique along sheltered coasts (i.e., coasts not exposed to open ocean wave energy) to preserve and improve habitats and their ecosystem services at the land-water interface. Toward this end, NOAA encourages early coordination across multiple scales of government and with other entities outside the government to develop shoreline management approaches that lead to the best shoreline stabilization options for a particular site. While this document focuses on sheltered coasts, NOAA has a broad interest in maintaining existing natural habitats that provide shoreline protection, like coral reefs, oyster reefs, mangroves, seagrass beds and marshes, along all coasts. This guidance is intended to provide information on NOAA's perspective and roles regarding living shorelines implementation. It starts by describing NOAA living shorelines guiding principles, then highlights NOAA's role in providing science, tools, and training to help inform the selection of appropriate techniques. It also discusses the agency's role in reviewing living shoreline projects, depending on their location and potential effect on habitats of concern to NOAA, such as critical habitat, essential fish habitat, or protected areas. This guidance also provides a conceptual framework of 12 questions to 
help NOAA and our partners when planning a shoreline stabilization effort."

https://www.habitatblueprint.noaa.gov/wp-content/uploads/2018/01/NOAA-Guidance-forConsidering-the-Use-of-Living-Shorelines_2015.pdf.

Piazza, B. P., P. D. Banks, and M. K. La Peyre. 2005. "The Potential for Created Oyster Shell Reefs as a Sustainable Shoreline Protection Strategy in Louisiana." Restoration Ecology 13: 499-506. https://doi.org/10.1111/j.1526-100X.2005.00062.x

Walker, R., B. Bendall, and L. Wallendorf. 2011. "Defining Engineering Guidance for Living Shoreline Projects.” Coastal Engineering Practice 1,064-1,077. https://ascelibrary.org/doi/10.1061/41190\%28422\%2986.

Wigand, C., T. Ardito, C. Chaffee, W. Ferguson, S. Paton, K. Raposa, C. Vandemoer, and E. Watson. 2015. "A Climate Change Adaptation Strategy for Management of Coastal Marsh Systems.” Estuaries and Coasts 40(3): 682-693.

https://doi.org/10.1007/s12237-015-0003-y

\section{Marsh Terracing}

Armitage, A. R., C. Ho, E. N. Madrid, M. T. Bell, and A. Quigg. 2014. "The Influence of Habitat Construction Technique on the Ecological Characteristics of a Restored Brackish Marsh." Ecological Engineering 62: 33-42. https://doi.org/10.1016/i.ecoleng.2013.10.021

Borde, A. B., L.K. O'Rourke, R. M. Thom, G. W. Williams, and H. L. Diefenderfer. 2004. National Review of Innovative and Successful Coastal Habitat Restoration. Prepared for National Oceanic and Atmospheric Administration Coastal Services Center. Battelle Memorial Institute, Contract 44188. Sequim, WA.

"Coastal habitat restoration is a burgeoning science, with numerous organizations participating in an increasing number of projects and programs across the country. Examples of innovative and successful components of these efforts are summarized in this review. The 
information on projects and programs was collected through expert interviews and through a nationwide review of scientific literature, restoration plans, and Internet sources. The examples provided cover many coastal habitat types from the four coasts of the United States. The review provides information on restoration research and the innovative and successful components of funding, partnerships, planning, restoration methods and techniques, monitoring, adaptive management, information dissemination, and community involvement. The lessons learned from the experiences of the many sources noted in this review are summarized at the end of the paper. Through this work we hope to contribute toward the success of future restoration efforts."

https://repository.library.noaa.gov/view/noaa/2555

Feagin, R. A., and X. B. Wu. 2006. "Spatial Pattern and Edge Characteristics in Restored Terrace Versus Reference Salt Marshes in Galveston Bay." Wetlands 26: 1,004-1,011. https://doi.org/10.1672/0277-5212(2006)26[1004:SPAECI]2.0.C0;2

Ravens, T. M., R. C. Thomas, K. A. Roberts, and P. H. Santschi, 2009. "Causes of Salt Marsh Erosion in Galveston Bay, Texas." Journal of Coastal Research 252: 265-272.

https://doi.org/10.2112/07-0942.1

Rozas, L. P., and T. J. Minello. 2001. "Marsh Terracing as a Wetland Restoration Tool for Creating Fishery Habitat.” Wetlands 3: 327341.

https://doi.org/10.1672/0277-5212(2001)021[0327:MTAAWR]2.0.C0;2

Rozas, L. P., P. Caldwell, and T. J. Minello. 2005. "The Fishery Value of Salt Marsh Restoration Projects." Journal of Coastal Research 40: 37-50.

https://www.jstor.org/stable/25736614

Zedler, J. B., and S. Kercher. 2005. "Wetland Resources: Status, Trends, Ecosystem Services, and Restorability." Annual Review of Environment and Resources 30: 39-74. 


\section{Sediment Fences}

Boumans, R. M. J., J. W. Day, G. P. Kemp, and K. Kilgen. 1997. "The Effect of Intertidal Sediment Fences on Wetland Surface Elevation, Wave Energy and Vegetation Establishment in Two Louisiana Coastal Marshes." Ecological Engineering 9: 37-50.

https://doi.org/10.1016/S0925-8574(97)00028-1

Callaway, J. C., V. T. Parker, M. C. Vasey, and L. M. Schile. 2007.

"Emerging Issues for the Restoration of Tidal Marsh Ecosystems in the Context of Predicted Climate Change.” Madroño 54: 234-248. https://doi.org/10.3120/0024-9637(2007)54|234:EIFTR0|2.0.C0;2

Day, J. W., Jr., D. Pont, P. F. Hensel, and C. Ibanez. 1995. "Impacts of SeaLevel Rise on Deltas in the Gulf of Mexico and the Mediterranean: The Importance of Pulsing Events to Sustainability." Estuaries 18: 636-647.

https://doi.org/10.2307/1352382

Koo, B. J., J. G. Je, and H. J. Woo. 2011. "Experimental Restoration of a Salt Marsh with Some Comments on Ecological Restoration of Coastal Vegetated Ecosystems in Korea." Ocean Science Journal 46: 47-53.

https://doi.org/10.1007/s12601-011-0004-0

Lowe, J., and J. Bourgeois. 2015. "Science Foundation Chapter 2 - The Projected Evolution of Baylands Habitats." In Baylands Ecosystem Habitat Goals Science Update 2015. Prepared by the San Francisco Bay Area Wetlands Ecosystem Goals Project. Oakland, CA: California State Coastal Conservancy.

"The projected drivers for change, in particular climate and sea level, will likely affect the evolution of baylands habitats over the next century. We understand the baylands to be evolving in three major directions; vertical accretion based on sediment supply and organic accumulation, landward migration (also called transgression) based on availability of terrestrial transition zone space, and lateral movement of the bayward marsh edge. Because tidal marshes are highly sensitive to elevation, their sustainability in San Francisco Bay (and elsewhere) will depend on the balance 
between sea-level rise and marsh sediment accretion (Michener et al. 1997, Morris et al. 2002). As discussed in Science Foundation Chapter 1, the existing marshes have a range of elevations covering low to high marsh; the higher parts of the marshes give substantial "elevation capital" (Cahoon and Guntenspergen 2010), i.e., they have elevation to lose before they convert to unvegetated mudflat.

This raises two key questions: firstly, how are baylands habitats (e.g., marshes, mudflats and managed ponds) likely to evolve over the next century? To answer this question we need to understand the present evolution and then make projections of future evolution. Once we understand the future evolution we can address the second key question: what management actions can we take to guide the evolution of baylands habitat in the short- and long-term? The decision about when to implement each of these measures will depend on the rate of sea-level rise, and in particular when certain threshold elevations will be crossed that trigger the need for intervention."

https://baylandsgoals.org/wp-content/uploads/2015/10/BEHGU_SFC2.pdf

Scarton, F., J. W. Day, Jr, A. Rismondo, G. Cecconi, and D. Are. 2000. "Effects of an Intertidal Sediment Fence on Sediment Elevation and Vegetation Distribution in a Venice (Italy) Lagoon Salt Marsh.” Ecological Engineering 16: 223-233. https://doi.org/10.1016/S0925-8574(00)00045-8

\section{Inland Migration}

Burkett, V., and J. Kusler. 2000. "Climate Change: Potential Impacts and Interactions in Wetlands of the United States." Journal of the American Water Resources Association 36: 313-320. https://doi.org/10.1111/i.1752-1688.2000.tb04270.x

Callaway, J. C., V. T. Parker, M. C. Vasey, and L. M. Schile. 2007. "Emerging Issues for the Restoration of Tidal Marsh Ecosystems in the Context of Predicted Climate Change." Madroño 54: 234-248. https://doi.org/10.3120/0024-9637(2007)54[234:EIFTR0]2.0.C0;2 
Clausen, K. K., M. Stjernholm, and P. Clausen. 2013. "Grazing Management Can Counteract the Impacts of Climate ChangeInduced Sea Level Rise on Salt Marsh-Dependent Waterbirds.” Journal of Applied Ecology 50: 528-537.

https://doi.org/10.1111/1365-2664.12043

Craft, C., J. Clough, J. Ehman, S. Joye, R. Park, S. Pennings, H. Guo, and M. Machmuller. 2008. "Forecasting the Effects of Accelerated SeaLevel Rise on Tidal Marsh Ecosystem Services." Frontiers in Ecology and the Environment 7: 73-78.

https://doi.org/10.1890/070219

Day, J. W., R. R. Christian, D. M. Boesch, A. Yáñez-Arancibia, J. Morris, R. R. Twilley, L. Naylor, L. Schaffner, and C. Stevenson. 2008. "Consequences of Climate Change on the Ecogeomorphology of Coastal Wetlands." Estuaries and Coasts 31: 477-491. https://doi.org/10.1007/s12237-008-9047-6

FitzGerald, D., M. S. Fenster, B. A. Argow, and I. V. Buynevich. 2008. "Coastal Impacts Due to Sea-Level Rise." Annual Reviews of Earth and Planetary Sciences 36: 601-647. https://doi.org/10.1146/annurev.earth.35.031306.140139

Galbraith, H., R. Jones, R. Park, J. Clough, S. Herrod-Julius, B. Harrington, and G. Page. 2002. "Global Climate Change and Sea Level Rise: Potential Losses of Intertidal Habitat for Shorebirds.” Waterbirds 25: 173-183.

https://doi.org/10.1675/1524-4695(2002)025[0173:GCCASLI2.0.C0;2

Gedan, K. B., B. R. Silliman, and M. D. Bertness. 2009. "Centuries of Human-Driven Change in Salt Marsh Ecosystems.” Annual Review of Marine Science 1: 117-141.

https://doi.org/10.1146/annurev.marine.010908.163930

Glick, P., J. Clough, A. Polaczyk, B. Couvillion, and B. Nunley. 2013. "Potential Effects of Sea-Level Rise on Coastal Wetlands in Southeastern Louisiana." Journal of Coastal Research 63: 211-233. https://doi.org/10.2112/SI63-0017.1 
Hartig, E. K., V. Gornitz, A. Kolker, F. Mushacke, and D. Fallon. 2002. "Anthropogenic and Climate-Change Impacts on Salt Marshes of Jamaica Bay, New York City.” Wetlands 22: 71-89. https://doi.org/10.1672/0277-5212(2002)022[0071:AACCI0]2.0.C0;2

Hughes, R. G. 2004. "Climate Change and Loss of Saltmarshes: Consequences for Birds.” Ibis 146: 21-28. https://doi.org/10.1111/i.1474-919X.2004.00324.x

Lowe, J., and J. Bourgeois. 2015. "Science Foundation Chapter 2 - The Projected Evolution of Baylands Habitats." In Baylands Ecosystem Habitat Goals Science Update 2015. Prepared by the San Francisco Bay Area Wetlands Ecosystem Goals Project. Oakland, CA: California State Coastal Conservancy.

"The projected drivers for change, in particular climate and sea level, will likely affect the evolution of baylands habitats over the next century. We understand the baylands to be evolving in three major directions; vertical accretion based on sediment supply and organic accumulation, landward migration (also called transgression) based on availability of terrestrial transition zone space, and lateral movement of the bayward marsh edge. Because tidal marshes are highly sensitive to elevation, their sustainability in San Francisco Bay (and elsewhere) will depend on the balance between sea-level rise and marsh sediment accretion (Michener et al. 1997, Morris et al. 2002). As discussed in Science Foundation Chapter 1, the existing marshes have a range of elevations covering low to high marsh; the higher parts of the marshes give substantial "elevation capital" (Cahoon and Guntenspergen 2010), i.e., they have elevation to lose before they convert to unvegetated mudflat.

This raises two key questions: firstly, how are baylands habitats (e.g., marshes, mudflats and managed ponds) likely to evolve over the next century? To answer this question we need to understand the present evolution and then make projections of future evolution. Once we understand the future evolution we can address the second key question: what management actions can we take to guide the evolution of baylands habitat in the short- and long-term? The decision about when to implement each of these measures will depend on the rate of sea-level rise, and in particular when certain 
threshold elevations will be crossed that trigger the need for intervention."

https://baylandsgoals.org/wp-content/uploads/2015/10/BEHGU_SFC2.pdf

Moorhead, K. K., and M. M. Brinson. 1995. "Response of Wetlands to Rising Sea Level in the Lower Coastal Plain of North Carolina." Ecological Applications 5: 261-271.

https://doi.org/10.2307/1942068

Pethick, J. 1993. "Shoreline Adjustments and Coastal Management: Physical and Biological Processes under Accelerated Sea-Level Rise." The Geographical Journal 2: 162-168.

https://doi.org/10.2307/3451406

Pethick, J. 2001. "Coastal Management and Sea-Level Rise." Catena 42: 307-322.

https://doi.org/10.1016/S0341-8162(00)00143-0

Stralberg, D., M. Brennan, J. C. Callaway, J. K. Wood, L. M. Schile, D. Jongsomjit, M. Kelly, V. T. Parker, and S. Crooks. 2011. "Evaluating Tidal Marsh Sustainability in the Face of Sea-Level Rise: A Hybrid Modeling Approach Applied to San Francisco Bay.” PLoS One 6: e27388.

https://doi.org/10.1371/journal.pone.0027388

Wigand, C., T. Ardito, C. Chaffee, W. Ferguson, S. Paton, K. Raposa, C. Vandemoer, and E. Watson. 2015. "A Climate Change Adaptation Strategy for Management of Coastal Marsh Systems.” Estuaries and Coasts 40(3): 682-693.

https://doi.org/10.1007/s12237-015-0003-y

\section{Initial Assessments}

Blum, M. D., and H. H. Roberts. 2009. "Drowning of the Mississippi Delta Due to Insufficient Sediment Supply and Global Sea-Level Rise.” Nature Geoscience 2: 488-491. https://doi.org/10.1038/nge0553 
Boesch, D. E., M. N. Josselyn, A. J. Mehta, J. T. Morris, W. K. Nuttle, C. A. Simenstad, and D. J. P. Swift. 1994. "Scientific Assessment of Coastal Wetland Loss, Restoration and Management in Louisiana." Journal of Coastal Research 20: 103.

https://www.jstor.org/stable/25735693

Borde, A. B., L.K. O'Rourke, R. M. Thom, G. W. Williams, and H. L. Diefenderfer. 2004. National Review of Innovative and Successful Coastal Habitat Restoration. Prepared for National Oceanic and Atmospheric Administration Coastal Services Center. Battelle Memorial Institute, Contract 44188. Sequim, WA.

"Coastal habitat restoration is a burgeoning science, with numerous organizations participating in an increasing number of projects and programs across the country. Examples of innovative and successful components of these efforts are summarized in this review. The information on projects and programs was collected through expert interviews and through a nationwide review of scientific literature, restoration plans, and Internet sources. The examples provided cover many coastal habitat types from the four coasts of the United States. The review provides information on restoration research and the innovative and successful components of funding, partnerships, planning, restoration methods and techniques, monitoring, adaptive management, information dissemination, and community involvement. The lessons learned from the experiences of the many sources noted in this review are summarized at the end of the paper. Through this work we hope to contribute toward the success of future restoration efforts."

https://repository.library.noaa.gov/view/noaa/2555

Boumans, R., and J. W. Day, Jr. 1993. "High Precision Measurements of Sediment Elevation in Shallow Coastal Areas Using a Sedimentation-Erosion Table." Estuaries 16: 375-380. https://doi.org/10.2307/1352509

Cahoon, D. R., and R. E. Turner. 1989. "Accretion and Canal Impacts in a Rapidly Subsiding Wetland II: Feldspar Marker Horizon Technique." Estuaries 12: 260-268. 
Cahoon, D. R., D. J. Reed, and J. W. Day, Jr. 1995. "Estimating Shallow Subsidence in Microtidal Salt Marshes of the Southeastern United States: Kaye and Barghoon revisited.” Marine Geology 128: 1-9. https://doi.org/10.1016/0025-3227(95)00087-F

Cahoon, D. R., J. C. Lynch, P. F. Hensel, R. Boumans, B. C. Perez, B. Segura, and J. W. Day, Jr. 2002a. "High Precision Measurement of Wetland Sediment Elevation: I. Recent Improvements to the Sedimentation-Erosion Table." Journal of Sediment Research 72: 730-733.

\section{https://doi.org/10.1306/020702720730}

Cahoon, D. R., J. C. Lynch, B. C. Perez, B. Segura, R. Holland, C. Stelly, G. Stephenson, and P. Hensel. 2002b. "High Precision Measurement of Wetland Sediment Elevation: II. The Rod Surface Elevation Table.” Journal of Sediment Research 72: 734-739.

https://doi.org/10.1306/020702720734

Cahoon, D. R., P. F. Hensel, T. Spencer, D. J. Reed, K. L. McKee, and N. Saintilan. 2006. "Coastal Wetland Vulnerability to Relative SeaLevel Rise: Wetland Elevation Trends and Process Controls." Ecological Studies 190: 271-292. https://doi.org/10.1007/978-3-540-33187-2_12

Craft, C., J. Clough, J. Ehman, S. Joye, R. Park, S. Pennings, H. Guo, and M. Machmuller. 2008. "Forecasting the Effects of Accelerated SeaLevel Rise on Tidal Marsh Ecosystem Services." Frontiers in Ecology and the Environment 7: 73-78.

https://doi.org/10.1890/070219

Day, J. W., Jr., and P. H. Templet. 1989. "Consequences of Sea Level Rise: Implications from the Mississippi Delta.” Coastal Management 17: 241-257. https://doi.org/10.1007/978-94-009-2003-3_19 
Day, J. W., Jr., D. Pont, P. F. Hensel, and C. Ibanez. 1995. "Impacts of SeaLevel Rise on Deltas in the Gulf of Mexico and the Mediterranean: The Importance of Pulsing Events to Sustainability.” Estuaries 18: 636-647.

https://doi.org/10.2307/1352382

Day, J. W., Jr., J. F. Martin, L. Cardoch, and P. H. Templet. 1997. "System Functioning as a Basis for Sustainable Management of Deltaic Ecosystems." Coastal Management 25: 115-153. https://doi.org/10.1080/08920759709362315

Day, J. W., G. P. Kemp, D. J. Reed, D. R. Cahoon, R. M. Boumans, J. M. Suhayda, and R. Gambrell. 2011. "Vegetation Death and Rapid Loss of Surface Elevation in Two Contrasting Mississippi Delta Salt Marshes: The Role of Sedimentation, Autocompaction, and SeaLevel Rise.” Ecological Engineering 37: 229-240.

https://doi.org/10.1016/j.ecoleng.2010.11.021

Donnelly, J. P., and M. D. Bertness. 2001. "Rapid Shoreward Encroachment of Salt Marsh Cordgrass in Response to Accelerated Sea-Level Rise." PNAS 98: 14,218-14,223.

https://doi.org/10.1073/pnas.251209298

Erwin, M. R., G. M. Sanders, and D. J. Prosser. 2004. "Changes in Lagoonal Marsh Morphology at Selected Northeastern Atlantic Coast Sites of Significance to Migratory Seabirds.” Wetlands 24: 891-903.

https://doi.org/10.1672/0277-5212(2004)024[0891:CILMMA]2.0.C0;2

Fagherazzi, S., M. L. Kirwan, S. M. Mudd, G. R. Guntenspergen, S. Temmerman, A. D'Alpaos, J. van de Koppel, J. M. Rybczyk, E. Reyes, C. Craft, and J. Clough. 2012. "Numerical Models of Salt Marsh Evolution: Ecological, Geomorphic, and Climatic Factors." Rev. Geophys. 50: RG1002. doi:10.1029/2011RG000359.

https://doi.org/10.1029/2011RG000359

French, J. R. 1993. "Numerical Simulation of Vertical Marsh Growth and Adjustment to Accelerated Sea-Level Rise, North Norfolk, U.K." Earth Surface Processes and Landforms 18: 63-81. 
French, J. R. 2006. "Tidal Marsh Sedimentation and Resilience to Environmental Change: Exploratory Modelling of Tidal, Sea-Level, and Sediment Supply Forcing in Predominately Allochthonous Systems." Marine Geology 235: 119-136.

https://doi.org/10.1016/i.marge0.2006.10.009

Friedrichs, C. T., and J. E. Perry. 2001. "Tidal Salt Marsh Morphodynamics: A Synthesis.” Journal of Coastal Research 27: 7-37.

http://www.jstor.org/stable/25736162

Ganju, N. K., M. L. Kirwan, P. J. Dickhudt, G. R. Guntenspergen, D. R. Cahoon, and K. D. Kroeger. 2015. "Sediment Transport-Based Metrics of Wetland Stability." Geophysical Research Letters 42: 7,992-8,000. https://doi.org/10.1002/2015GL065980

Gesch, D. B. 2009. "Analysis of LiDAR Elevation Data for Improved Identification and Delineation of Lands Vulnerable to Sea-Level Rise." Journal of Coastal Research 53: 49-58.

https://doi.org/10.2112/SI53-006.1

Glick, P., J. Clough, A. Polaczyk, B. Couvillion, and B. Nunley. 2013. "Potential Effects of Sea-Level Rise on Coastal Wetlands in Southeastern Louisiana." Journal of Coastal Research 63: 211-233. https://doi.org/10.2112/SI63-0017.1

Hartig, E. K., V. Gornitz, A. Kolker, F. Mushacke, and D. Fallon. 2002. "Anthropogenic and Climate-Change Impacts on Salt Marshes of Jamaica Bay, New York City.” Wetlands 22: 71-89. https://doi.org/10.1672/0277-5212(2002)022[0071:AACCI0]2.0.C0;2

Heberger, M., H. Cooley, P. Herrera, P. H. Gleick, and E. Moore. 2009. The Impacts of Sea-Level Rise on the California Coast. California Climate Change Center, CEC-500-2009-024-F.

"Over the past century, sea level has risen nearly eight inches along the California coast, and general circulation model scenarios suggest very substantial increases in sea level as a significant impact of climate change over the coming century. This study includes a 
detailed analysis of the current population, infrastructure, and property at risk from projected sea-level rise if no actions are taken to protect the coast. The sea-level rise scenario was developed by the State of California from medium to high greenhouse gas emissions scenarios from the Intergovernmental Panel on Climate Change (IPCC) but does not reflect the worst-case sea-level rise that could occur. We also evaluate the cost of building structural measures to reduce that risk. If development continues in the areas at risk, all of these estimates will rise. No matter what policies are implemented in the future, sea-level rise will inevitably change the character of the California coast. We estimate that a 1.4 meter sealevel rise will put 480,000 people at risk of a 100-year flood event, given today's population. Among those affected are large numbers of low-income people and communities of color, which are especially vulnerable. Critical infrastructure, such as roads, hospitals, schools, emergency facilities, wastewater treatment plants, power plants, and more will also be at increased risk of inundation, as are vast areas of wetlands and other natural ecosystems. In addition, the cost of replacing property at risk of coastal flooding under this sea-level rise scenario is estimated to be nearly $\$ 100$ billion (in year 2000 dollars). A number of structural and non-structural policies and actions could be implemented to reduce these risks. For example, we estimate that protecting some vulnerable areas from flooding by building seawalls and levees will cost at least $\$ 14$ billion (in year 2000 dollars), with added maintenance costs of another $\$ 1.4$ billion per year. Continued development in vulnerable areas will put additional areas at risk and raise protection costs. Large sections of the Pacific coast are not vulnerable to flooding, but are highly susceptible to erosion. We estimate that a 1.4 meter sea-level rise will accelerate erosion, resulting in a loss of 41 square miles (over 26,000 acres) of California's coast by 2100 . A total of 14,000 people currently live in the area at risk of future erosion. Additionally, significant transportation related infrastructure and property are vulnerable to erosion. Statewide flood risk exceeds erosion risk, but in some counties and localities, coastal erosion poses a greater risk. This report also provides a comprehensive set of recommendations and strategies for adapting to sea-level rise." 
Hine, S. K. 2015. Adapting to Rising Sea Levels in San Francisco Bay: The Potential for Thin Layer Sediment Application to Enhance Tidal Marsh Resiliency through This Century. Master's Projects. Paper 275. The University of San Francisco.

https://repository.usfca.edu/capstone/275

Hinkle, R. L., and W. J. Mitsch. 2005. "Salt Marsh Vegetation Recovery at Salt Hay Farm Wetland Restoration Sites on Delaware Bay." Ecological Engineering 25: 240-251.

https://doi.org/10.1016/j.ecoleng.2005.04.011

Kirwan, M. L., and A. B. Murray. 2007. "A Coupled Geomorphic and Ecological Model of Tidal Marsh Evolution.” PNAS 104: 6,1186,122 .

https://doi.org/10.1073/pnas.0700958104

MacBroom, J. G., and R. Schiff. 2012. "Predicting the Hydrologic Response of Salt Marshes to Tidal Restoration." In Tidal Marsh Restoration: A Synthesis of Science and Management, edited by C. T. Roman and D. M. Burdick. Washington, DC: Island Press. https://doi.org/10.5822/978-1-61091-229-7_2

Mariotti, G., and S. Fagherazzi. 2013. "Critical Width of Tidal Flats Triggers Marsh Collapse in the Absence of Sea-Level Rise.” PNAS 10(14): 5,353-5,356.

https://doi.org/10.1073/pnas.1219600110

Martin, J. F., E. Reyes, G. P. Kemp, H. Mashriqui, and J. W. Day, Jr. 2002. "Landscape Modeling of the Mississippi Delta." BioScience 52: $356-365$.

https://doi.org/10.1641/0006-3568(2002)052[0357:LMOTMD]2.0.C0;2

Morris, J. T., P. V. Sundareshwar, C. T. Nietch, B. Kjerfve, and D. R. Cahoon. 2002. "Response of Coastal Wetlands to Rising Sea Level." Ecology 83: 2,869-2,877. https://doi.org/10.1890/0012-9658(2002)083[2869:ROCWTR]2.0.C0;2 
National Park Service (NPS), U.S. Department of the Interior, Jamaica Bay Institute, Gateway National Recreational Area. 2004. "Jamaica Bay's Disappearing Marshes.” In Proceedings. New York Aquarium Scientific Symposium and Public Forum.

This is a proceedings document for a symposium on Jamaica Bay's disappearing marshes that took place in New York in 2004.

https://seagrant.sunysb.edu/Images/Uploads/PDFs/themeareas/CComm-Habitat/MarshLossProc0304.pdf

O’Neill, V. 2015. Long Island Sound Tidal Wetlands Loss Workshop. Workshop Proceedings and Recommendations to the Management Committee of the Long Island Sound Study. October 22-23, 2014. Port Jefferson, NY.

"Tidal wetlands, particularly salt marshes, are primarily composed of smooth cordgrass (Spartina alterniflora) and saltmeadow cordgrass (Spartina patens) and can be found throughout Long Island Sound (LIS) in protected bays and harbors. These wetland habitats serve as the interface between the marine and the terrestrial environment, providing buffers to storm surge, filtering the water of pollutants to improve water quality, and serving as spawning, nursery, and feeding grounds for fish, invertebrates, waterfowl, and wading birds.

Despite their benefits, tidal wetland ecosystems were not fully understood or appreciated until the mid-2oth century and until this time suffered from years of dredging and filling related to land and port development. By the 1970s, legislation was initiated in New York and Connecticut to protect tidal wetlands from destruction. Despite these protections, in 1999 the New York State Department of Environmental Conservation (NYSDEC) staff identified significant losses in intertidal marshes in Jamaica Bay, Queens, NY, and documented similar intertidal marsh losses in other New York estuaries. At the same time, Connecticut Department of Environmental Protection (today, the Connecticut Department of Energy and Environmental Protection (CTDEEP)) noted consistent and continued wetland loss in the tidal portions of the rivers that drain into LIS. As a result of these findings, the Long Island Sound Study (LISS) Management Committee funded a Long Island Sound 
Tidal Wetland Loss Workshop in 2003 to bring together experts and investigate this phenomenon. Ultimately, the workshop determined that the causative factors of marsh loss were largely unknown and that more research, monitoring, restoration, and man.

http://longislandsoundstudy.net/wp-content/uploads/2015/07/LIS-TWL-Workshop-2014Proceedings_FINAL.pdf

Orson, R. A., R. S. Warren, and W. A. Niering. 1998. "Interpreting SeaLevel Rise and Rates of Vertical Marsh Accretion in a Southern New England Tidal Salt Marsh." Estuarine, Coastal and Shelf Science 47: 19-429.

https://doi.org/10.1006/ecss.1998.0363

Reed, D. J., T. Spencer, A. L. Murray, J. R. French, and L. Leonard. 1999. "Marsh Surface Sediment Deposition and the Role of Tidal Creeks: Implications for Created and Managed Coastal Marshes.” Journal of Coastal Conservation 5: 81-90.

https://doi.org/10.1007/BF02802742

Roman, C. T., J. A. Peck, J. R. Allen, J. W. King, and P. G. Appleby. 1997. "Accretion of a New England (U.S.A.) Salt Marsh in Response to Inlet Migration Storms and Sea-Level Rise." Estuarine, Coastal and Shelf Science 45: 717-727. https://doi.org/10.1006/ecss.1997.0236

Schile, L. M., J. C. Callaway, J. T. Morris, D. Stralberg, V. T. Parker, and M. Kell. 2014. "Modeling Tidal Marsh Distribution with Sea-Level Rise: Evaluating the Role of Vegetation, Sediment, and Upland Habitat in Marsh Resiliency." PLoS ONE 9: e88760.

https://doi.org/10.1371/journal.pone.0088760

Stralberg, D., M. Brennan, J. C. Callaway, J. K. Wood, L. M. Schile, D. Jongsomjit, M. Kelly, V. T. Parker, and S. Crooks. 2011. "Evaluating Tidal Marsh Sustainability in the Face of Sea-Level Rise: A Hybrid Modeling Approach Applied to San Francisco Bay." PLoS One 6: e27388.

https://doi.org/10.1371/journal.pone.0027388 
Temmerman, S., G. Govers, S. Wartel, and P. Meire. 2004. "Modelling Estuarine Variations in Tidal Marsh Sedimentation: Response to Changing Sea Level and Suspended Sediment Concentrations.” Marine Geology 212: 1-19. https://doi.org/10.1016/i.marge0.2004.10.021

Thorne, K. M., G. M. MacDonald, R. F. Ambrose, K. J. Buffington, C. M. Freeman, C. N. Janousek, L. N. Brown, J. R. Holmquist, G. R. Guntenspergen, K. W. Powelson, P. L. Barnard, and J. Y. Takekawa. 2016. Effects of Climate Change on Tidal Marshes along a Latitudinal Gradient in California. U.S. Geological Survey OpenFile Report 2016-1125.

"The coastal region of California supports a wealth of ecosystem services including habitat provision for wildlife and fisheries. Tidal marshes, mudflats, and shallow bays within coastal estuaries link marine, freshwater and terrestrial habitats, and provide economic and recreational benefits to local communities. Climate change effects such as sea-level rise (SLR) are altering these habitats, but we know little about how these areas will change over the next 50100 years. Our study examined the projected effects of three recent SLR scenarios produced for the West Coast of North America on tidal marshes in California. We compiled physical and biological data, including coastal topography, tidal inundation, plant composition, and sediment accretion to project how SLR may alter these ecosystems in the future. The goal of our research was to provide results that support coastal management and conservation efforts across California. Under a low SLR scenario, all study sites remained vegetated tidal wetlands, with most sites showing little elevation and vegetation change relative to sea level. At most sites, mid SLR projections led to increases in low marsh habitat at the expense of middle and high marsh habitat. Marshes at Morro Bay and Tijuana River Estuary were the most vulnerable to mid SLR with many areas becoming intertidal mudflat. Under a high SLR scenario, most sites were projected to lose vegetated habitat, eventually converting to intertidal mudflats. Our results suggest that California marshes are vulnerable to major habitat shifts under mid or high rates of SLR, especially in the latter part of the century. Loss of vegetated tidal marshes in California due to SLR is expected to impact ecosystem services that are dependent on coastal 
wetlands such as wildlife habitat, carbon sequestration, improved water quality, and coastal protection from storms."

https://doi.org/10.3133/ofr20161125

Tobias, V. D., J. A. Nyman, R. D. DaLaune, and J. D. Foret. 2010.

"Improving Marsh Restoration: Leaf Tissue Chemistry Identifies Factors Limiting Production in Spartina patens." Plant Ecology 207: 141-148.

https://doi.org/10.1007/s11258-009-9660-x

Turner, R. E., and D. R. Cahoon, editors. 1987. Causes of Wetland Loss in the Coastal Central Gulf of Mexico. Volume I: Executive Summary. Final report submitted to Minerals Management Service, New Orleans, LA. Contract No. 14-12-0001-30252. OCS Study/MNIS 870119. New Orleans, LA.

"The purpose of this study was to determine the extent to which the most extensive offshore oil and gas activity in the U. S. is contributing to the well documented and dramatic alteration of Louisiana, Texas and Mississippi onshore wetland habitats (from East Bay, Texas to Waveland, Mississippi; Figure 1). These coastal wetlands converted to open water at an average annual rate of 12,700 ha ( 1 ha $=2.47$ acres) or $0.86 \%$ from $1955 / 6^{*}$ to 1978 , thereby continuing a geometric increase this century (Figure 2). There is, naturally, concern about these habitat changes because of the enormous economic, social, geopolitical, and environmental values involved in such massive and rapid landscape alterations (Table 1). These wetlands directly support $28 \%$ of the national fisheries harvest, the largest fur harvest in the U.S., the largest concentration of overwintering waterfowl in the U.S., a majority of the marine recreational fishing landings, and a variety of wildlife." https://www.boem.gov/ESPIS/3/3778.pdf

Twohig, T. M., and M. H. Stolt. 2011. "Soils-Based Rapid Assessment for Quantifying Changes in Salt Marsh Condition as a Result of Hydrologic Alteration." Wetlands 31: 955-963.

https://doi.org/10.1007/s13157-011-0210-7 
U.S. Department of Interior Fish and Wildlife Service (US FWS). 2014a. Environmental Assessment for the Narrow River Estuary Resilience Restoration Program. Rhode Island National Wildlife Refuge Complex, Charlestown, RI.

This is a regulatory document for a thin layer placement project in Rhode Island that was initiated in 2016.

US FWS. 2014b. Final Initial Study/Environmental Assessment for the Seal Beach National Wildlife Refuge Thin-Layer Salt Marsh Sediment Augmentation Pilot Project Orange County, California. San Diego National Wildlife Refuge Complex, Chula Vista, CA.

This is a regulatory document for a thin layer placement project in California that was initiated in 2016. http://scc.ca.gov/webmaster/ftp/pdf/sccbb/2014/1410/20141002Board11_Seal_Beach_Se diment_Augmentation_Ex4.pdf

Van Wijnen, H. J., and J. P. Bakker. 2000. “Long-Term Surface Elevation Change in Salt Marshes: A Prediction of Marsh Response to Future Sea-Level Rise. Estuarine, Coastal and Shelf Science 52: 381-390.

https://doi.org/10.1006/ecss.2000.0744

Webb, E. L., D. A. Friess, K. W. Krauss, D. R. Cahoon, G. R. Guntenspergen, and J. Phelps. 2013. "A Global Standard for Monitoring Coastal Wetland Vulnerability to Accelerated Sea-Level Rise." Nature Climate Change 3: 458-465.

https://doi.org/10.1038/nclimate1756

Weinstein, M. P., J. M. Teal, J. H. Balletto, and K. A. Strait. 2001. "Restoration Principles Emerging from One of the World's Largest Tidal Marsh Restoration Projects." Wetlands Ecology and Management 9: 387-407.

https://doi.org/10.1023/A:1012058713910

Wigand, C., T. Ardito, C. Chaffee, W. Ferguson, S. Paton, K. Raposa, C. Vandemoer, and E. Watson. 2015. "A Climate Change Adaptation Strategy for Management of Coastal Marsh Systems." Estuaries and Coasts 40(3): 682-693.

https://doi.org/10.1007/s12237-015-0003-y 
Wu W., K. M. Yeager, M. S. Peterson, and R. S. Fulford. 2015. "Neutral Models as a Way to Evaluate the Sea Level Affecting Marshes Model (SLAMM).” Ecological Modelling 303: 55-69.

https://doi.org/10.1016/j.ecolmodel.2015.02.008

\section{Metrics}

Adam, P. 2009. "Salt Marsh Restoration." In Coastal Wetlands: An Integrated Ecosystem Approach, edited by G. Perillo, E. Wolanski, D. Cahoon, and M. Brinson, 737-761. New York: Elsevier. This book chapter summarizes salt marsh restoration strategies including specifying objectives, planning for future conditions, addressing the cause of marsh degradation, and managing disturbances.

Armitage, A. R., C. Ho, E. N. Madrid, M. T. Bell, and A. Quigg. 2014. "The Influence of Habitat Construction Technique on the Ecological Characteristics of a Restored Brackish Marsh." Ecological Engineering 62: 33-42.

https://doi.org/10.1016/i.ecoleng.2013.10.021

Barber, A. 2014. Sediment and Vegetation Monitoring during a Levee Removal Project on the Stillaguamish River Delta at Port Susan Bay, WA. MS thesis, Western Washington University, Bellingham, WA.

https://cedar.wwu.edu/wwuet/379/

Bayard, T. S., and C. S. Elphick. 2011. "Planning for Sea-Level Rise: Quantifying Patterns of Saltmarsh Sparrow (Ammodramus caudacutus) Nest Flooding under Current Sea-Level Conditions." The Auk 128: 393-403.

https://doi.org/10.1525/auk.2011.10178

Borde, A. B., L.K. O'Rourke, R. M. Thom, G. W. Williams, and H. L. Diefenderfer. 2004. National Review of Innovative and Successful Coastal Habitat Restoration. Prepared for National Oceanic and Atmospheric Administration Coastal Services Center. Battelle Memorial Institute, Contract 44188. Sequim, WA. 
"Coastal habitat restoration is a burgeoning science, with numerous organizations participating in an increasing number of projects and programs across the country. Examples of innovative and successful components of these efforts are summarized in this review. The information on projects and programs was collected through expert interviews and through a nationwide review of scientific literature, restoration plans, and Internet sources. The examples provided cover many coastal habitat types from the four coasts of the United States. The review provides information on restoration research and the innovative and successful components of funding, partnerships, planning, restoration methods and techniques, monitoring, adaptive management, information dissemination, and community involvement. The lessons learned from the experiences of the many sources noted in this review are summarized at the end of the paper. Through this work we hope to contribute toward the success of future restoration efforts."

https://repository.library.noaa.gov/view/noaa/2555

Buchsbaum, R. N., and C. Wigand. 2012. "Adaptive Management and Monitoring as Fundamental Tools to Effective Salt Marsh Restoration.” In Tidal Marsh Restoration: A Synthesis of Science and Management, edited by C. T. Roman and D. M. Burdick. Washington, DC: Island Press. https://doi.org/10.5822/978-1-61091-229-7_14

Cahoon, D. 2006. "A Review of Major Storm Impacts on Coastal Wetland Elevations." Estuaries and Coasts 29: 889-898. https://doi.org/10.1007/BF02798648

Cahoon, D. R., D. J. Reed, and J. W. Day, Jr. 1995 “Estimating Shallow Subsidence in Microtidal Salt Marshes of the Southeastern United States: Kaye and Barghoon revisited." Marine Geology 128: 1-9. https://doi.org/10.1016/0025-3227(95)00087-F

Donnelly, J. P., and M. D. Bertness. 2001. "Rapid Shoreward Encroachment of Salt Marsh Cordgrass in Response to Accelerated Sea-Level Rise.” PNAS 98: 14,218-14,223.

https://doi.org/10.1073/pnas.251209298 
Eertman, R. H. M., B. A. Kornman, E. Stikvoort, and H. Verbeek. 2002. "Restoration of the Sieperda Tidal Marsh in the Scheldt Estuary, The Netherlands.” Restoration Ecology 10: 438-449.

https://doi.org/10.1046/j.1526-100X.2002.01034.X

Feagin, R. A., and X. B. Wu. 2006. "Spatial Pattern and Edge

Characteristics in Restored Terrace Versus Reference Salt Marshes in Galveston Bay." Wetlands 26: 1,004-1,011.

https://doi.org/10.1672/0277-5212(2006)26[1004:SPAEC||2.0.C0;2

Gulf Coast Ecosystem Restoration Council, Restore. n.d. Resources and Ecosystems Sustainability, Tourist Opportunities, and Revived Economies of the Gulf Coast States Act (RESTORE Act) Initial Funded Priorities List.

"The Gulf Coast region is vital to our nation and our economy, providing valuable energy resources, abundant seafood, extraordinary beaches and recreational activities, and a rich natural and cultural heritage. Its waters and coasts are home to one of the most diverse natural environments in the world - including over 15,000 species of sea life and millions of migratory birds. The Gulf has endured catastrophic events over the years, including major hurricanes such as Katrina, Rita, Gustav and Ike in the last 10 years alone. The region has also experienced the loss of critical wetland habitats, erosion of barrier islands, imperiled fisheries, water quality degradation and significant coastal land loss. More recently, the Deepwater Horizon oil spill significantly affected the health of the region's ecosystem. As a result of the oil spill, the Council has been given the great responsibility of helping to address ecosystem challenges across the Gulf."

Haltiner, J., J. B. Zedler, G. D. Williams, and J. C. Callaway. 1997. "Influence of Physical Processes on the Design, Functioning, and Evolution of Restored Tidal Wetlands in California." Wetlands Ecology and Management 4: 73-91.

https://doi.org/10.1007/BF01876230 
Hinkle, R. L., and W. J. Mitsch. 2005. "Salt Marsh Vegetation Recovery at Salt Hay Farm Wetland Restoration Sites on Delaware Bay." Ecological Engineering 25: 240-251.

https://doi.org/10.1016/j.ecoleng.2005.04.011

Hood, W. G. 2002. "Landscape Allometry: From Tidal Channel Hydraulic Geometry to Benthic Ecology." Canadian Journal of Fisheries and Aquatic Sciences 59: 1,418-1,427.

https://doi.org/10.1139/f02-109

Kentula, M. E. 2000. "Perspectives on Setting Success Criteria for Wetland Restoration.” Ecological Engineering 15: 199-209. https://doi.org/10.1016/S0925-8574(00)00076-8

Konisky, R. A., D. M. Burdick, M. Dionne, and H. A. Neckles. 2006. “A Regional Assessment of Salt Marsh Restoration and Monitoring in the Gulf of Maine." Restoration Ecology 14: 516-525.

https://doi.org/10.1111/j.1526-100X.2006.00163.x

Neckles, H. A., M. Dionne, D. M. Burdick, C. T. Roman, R. Buchsbaum, and E. Hutchins. 2002. "A Monitoring Protocol to Assess Tidal Restoration of Salt Marshes on Local and Regional Scales." Restoration Ecology 10: 556-563. https://doi.org/10.1046/i.1526-100X.2002.02033.x

Orson, R. A., R. S. Warren, and W. A. Niering. 1998. "Interpreting SeaLevel Rise and Rates of Vertical Marsh Accretion in a Southern New England Tidal Salt Marsh.” Estuarine, Coastal and Shelf Science 47: 19-429.

https://doi.org/10.1006/ecss.1998.0363

Roman, C. T., J. A. Peck, J. R. Allen, J. W. King, and P. G. Appleby. 1997. "Accretion of a New England (U.S.A.) Salt Marsh in Response to Inlet Migration Storms and Sea-Level Rise." Estuarine, Coastal and Shelf Science 45: 717-727.

https://doi.org/10.1006/ecss.1997.0236 
Short, F. T., D. M. Burdick, C. A. Short, R. C. Davis, and P. A. Morgan. 2000. "Developing Success Criteria for Restored Eelgrass, Salt Marsh and Mud Flat Habitat.” Ecological Engineering 15: 239252.

https://doi.org/10.1016/S0925-8574(00)00079-3

Weinstein, M. P., J. M. Teal, J. H. Balletto, and K. A. Strait. 2001.

"Restoration Principles Emerging from One of the World's Largest

Tidal Marsh Restoration Projects." Wetlands Ecology and

Management 9: 387-407.

https://doi.org/10.1023/A\%3A1012058713910

Wigand, C., T. Ardito, C. Chaffee, W. Ferguson, S. Paton, K. Raposa, C. Vandemoer, and E. Watson. 2015. "A Climate Change Adaptation Strategy for Management of Coastal Marsh Systems." Estuaries and Coasts 40(3): 682-693.

https://doi.org/10.1007/s12237-015-0003-y

Williams, G. D., and J. B. Zedler. 1999. "Fish Assemblage Composition in Constructed and Natural Tidal Marshes of San Diego Bay: Relative Influence of Channel Morphology and Restoration History."

Estuaries 22: 702-716.

https://doi.org/10.2307/1353057

Zhao, Q., J. Bai, L. Huang, B. Gu, Q. Lu, and Z. Gao. 2016. "A Review of Methodologies and Success Indicators for Coastal Wetland Restoration." Ecological Indicators 60: 442-452.

https://doi.org/10.1016/i.ecolind.2015.07.003

\section{Monitoring}

Adam, P. 2009. "Salt Marsh Restoration." In Coastal Wetlands: An Integrated Ecosystem Approach, edited by G. Perillo, E. Wolanski, D. Cahoon, and M. Brinson, 737-761. New York: Elsevier.

This book chapter summarizes salt marsh restoration strategies including specifying objectives, planning for future conditions, addressing the cause of marsh degradation, and managing disturbances. 
Armitage, A. R., C. Ho, E. N. Madrid, M. T. Bell, and A. Quigg. 2014. "The Influence of Habitat Construction Technique on the Ecological Characteristics of a Restored Brackish Marsh.” Ecological Engineering 62: 33-42.

https://doi.org/10.1016/i.ecoleng.2013.10.021

Barber, A. 2014. Sediment and Vegetation Monitoring during a Levee Removal Project on the Stillaguamish River Delta at Port Susan Bay, WA. MS thesis, Western Washington University, Bellingham, WA.

https://cedar.wwu.edu/wwuet/379/

Borde, A. B., L.K. O'Rourke, R. M. Thom, G. W. Williams, and H. L. Diefenderfer. 2004. National Review of Innovative and Successful Coastal Habitat Restoration. Prepared for National Oceanic and Atmospheric Administration Coastal Services Center. Battelle Memorial Institute, Contract 44188. Sequim, WA.

"Coastal habitat restoration is a burgeoning science, with numerous organizations participating in an increasing number of projects and programs across the country. Examples of innovative and successful components of these efforts are summarized in this review. The information on projects and programs was collected through expert interviews and through a nationwide review of scientific literature, restoration plans, and Internet sources. The examples provided cover many coastal habitat types from the four coasts of the United States. The review provides information on restoration research and the innovative and successful components of funding, partnerships, planning, restoration methods and techniques, monitoring, adaptive management, information dissemination, and community involvement. The lessons learned from the experiences of the many sources noted in this review are summarized at the end of the paper. Through this work we hope to contribute toward the success of future restoration efforts." 
Cahoon, D. R., and J. H. Cowan, Jr. 1987. Spray Disposal of Dredged Material in Coastal Louisiana: Habitat Impacts and Regulatory Policy Implications. Louisiana Sea Grant College Program, Louisiana State University, Baton Rouge, LA.

"Dredging canals for navigation, pipelines, and access to drilling sites is a common activity in the Louisiana coastal zone. Traditionally, the spoil dredged during construction is banked alongside the canal at elevations significantly higher than the surrounding marsh (Cahoon et al. 1986). In Louisiana marshes, spoil banks accommodate upland vegetation that was not present before the canals were dredged and often provide habitat for birds, waterfowl, and wildlife not found previously within the coastal area (Olson 1975; Bettinger and Hamilton 1985). It has been suggested that canals and their associated spoil banks contribute to land loss in the Louisiana coastal zone by (1) directly converting marsh habitat to open water and upland (spoil bank) habitat; and (2) altering the local hydrologic regime, i.e., sheetflow over the marsh, subsurface flow, and saltwater intrusion (Turner 1985; Swenson and Turner 1987). The cumulative effects of canals and their spoil banks on ecosystem hydrology and wetland loss may also be important (Turner 1985; Cowan et al. 1986). Minimizing the impacts associated with spoil banks is a major concern of state and federal agencies regulating development in wetlands. Current regulatory practices of the Louisiana Department of Natural Resources' Coastal Management Division (LDNR/CMD) require that access canals must be plugged and spoil either gapped or backfilled when wells are abandoned. The regulatory requirements of federal agencies such as the U.S. Fish and Wildlife Service (USFWS), the National Marine Fisheries Service (NMFS), and the U.S. Army Corps of Engineers (COE) are similar in intent and scope. Therefore, any new technology that minimizes spoil bank impacts would be of great interest to the regulatory agencies as a resource management tool. Industry, which must pay for mitigating the impacts of current dredging methods, also would be interested in any technology that speeds up the permitting process and reduces mitigation expenses, provided that it is not prohibitively expensive." 
Callaway, J. C., V. T. Parker, M. C. Vasey, and L. M. Schile. 2007.

"Emerging Issues for the Restoration of Tidal Marsh Ecosystems in the Context of Predicted Climate Change.” Madroño 54: 234-248.

https://doi.org/10.3120/0024-9637(2007)54[234:EIFTR0]2.0.C0;2

Callaway, J. C., G. Sullivan, J. S. Desmond, G. D. Williams, and J. B. Zedler. 2001. "Assessment and Monitoring." In Handbook for Restoring Tidal Wetlands. Boca Raton, FL: CRC Press LLS.

This book chapter synthesizes assessment, monitoring, and adaptive management of restored wetlands. Specific topics covered include hydrology, topography, water quality, soils, elevation, vegetation, invertebrates, and fish.

Craft, C., J. Reader, J. N. Sacco, and S. W. Broome. 1999. "Twenty-Five Years of Ecosystem Development of Constructed Spartina alterniflora (Loisel) Marshes.” Ecological Applications 9: 1,4051,419 .

https://doi.org/10.1890/1051-0761(1999)009[1405:TFYOED]2.0.C0;2

Day, J. W., G. P. Kemp, D. J. Reed, D. R. Cahoon, R. M. Boumans, J. M. Suhayda, and R. Gambrell. 2011. "Vegetation Death and Rapid Loss of Surface Elevation in Two Contrasting Mississippi Delta Salt Marshes: The Role of Sedimentation, Autocompaction, and SeaLevel Rise." Ecological Engineering 37: 229-240.

https://doi.org/10.1016/i.ecoleng.2010.11.021

DiGennaro, B., D. Reed, C. Swanson, L. Hastings, Z. Hymanson, M. Healey, S. Siegel, S. Cantrell, and B. Herbold. 2012. "Using Conceptual Models in Ecosystem Restoration Decision Making: An Example from the Sacramento-San Joaquin River Delta, California." San Francisco Estuary and Watershed Science 10: 115 .

https://doi.org/10.15447/sfews.2012v10iss3art1

Donnelly, J. P., and M. D. Bertness. 2001. "Rapid Shoreward Encroachment of Salt Marsh Cordgrass in Response to Accelerated Sea-Level Rise." PNAS 98: 14,218-14,223. 
Eertman, R. H. M., B. A. Kornman, E. Stikvoort, and H. Verbeek. 2002. "Restoration of the Sieperda Tidal Marsh in the Scheldt Estuary, The Netherlands." Restoration Ecology 10: 438-449.

https://doi.org/10.1046/j.1526-100X.2002.01034.x

Elliott, M., D. Burdon, K. L. Hemingway, and S. E. Apitz. 2007. "Estuarine, Coastal and Marine Ecosystem Restoration: Confusing Management and Science-A Revision of Concepts.” Estuarine Coastal and Shelf Science 74: 349-366.

https://doi.org/10.1016/j.ecss.2007.05.034

Ewel, K. C., C. Cressa, R. T. Kneib, P. S. Lake, L. A. Levin, M. A. Palmer, P. Snelgrove, and D. H. Wall. 2001. "Managing Critical Transition Zones." Ecosystems 4: 452-460. https://doi.org/10.1007/s10021-001-0106-0

Fischenich, C. 2008. The Application of Conceptual Models to Ecosystem Restoration. EBA Technical Notes Collection. ERDC/EBA TN-o8-1. Vicksburg, MS: U.S. Army Engineer Research and Development Center. www.wes.army.mil/el/emrrp.

"In its report to the Chief of Engineers, the U.S. Army Corps of Engineers (USACE) Environmental Advisory Board (EAB) recommended that (USACE, EAB 2006):

The Corps should encourage the explicit use of conceptual models to guide eco-system restoration planning and implementation. Conceptual models should be required as a first step in the planning process, as they provide a key link between early planning (e.g., an effective statement of problem, need, opportunity, and constraint) and later evaluation and implementation.

Conceptual models are descriptions of the general functional relationships among essential com-ponents of an ecosystem. They tell the story of "how the system works" and, in the case of ecosystem restoration, how restoration actions aim to alter those processes or attributes for the betterment of the system. As such, conceptual models can provide the Ecosystem Restoration Team with:

- a synthesis of the current understanding of how a system works 
- help in understanding and diagnosing the underlying problem

- a basis for isolating cause and effect and simplifying complex systems

- a common framework or "mental picture" from which to develop alternatives

- a tool for making qualitative predictions of ecosystem response

- a way to flag potential thresholds, from which system responses may accelerate or follow potentially unexpected or divergent paths

- a means by which to outline further restoration, $\mathrm{R} \& \mathrm{D}$, and computational efforts

- a supplement to numerical models for assessing project benefits and impacts

- a means of identifying appropriate monitoring indicators and metrics, and

- a basis for implementing adaptive management strategies

Most professionals rely heavily upon conceptual models, but few explicitly formulate and express the models such that they provide broad utility for ecosystem restoration. Model building consists of determining system parts, choosing the relationships that link these parts, specifying the mechanisms by which the parts interact, identifying missing information, and exploring the model behavior (Heemskerk et al. 2003). The model building process can be as enlightening as the model itself, because it reveals what is known and what is unknown about the connections and causalities in the systems under study."

http://hdl.handle.net/11681/4060

Glick, P., J. Clough, A. Polaczyk, B. Couvillion, and B. Nunley. 2013. "Potential Effects of Sea-Level Rise on Coastal Wetlands in Southeastern Louisiana." Journal of Coastal Research 63: 211-233. https://doi.org/10.2112/SI63-0017.1

Hackney, C. T. 2000. "Restoration of Coastal Habitats: Expectation and Reality.” Ecological Engineering 15: 165-170. 
Haltiner, J., J. B. Zedler, G. D. Williams, and J. C. Callaway. 1997. "Influence of Physical Processes on the Design, Functioning, and Evolution of Restored Tidal Wetlands in California." Wetlands Ecology and Management 4: 73-91.

https://doi.org/10.1007/BF01876230

Kentula, M. E. 2000. "Perspectives on Setting Success Criteria for Wetland Restoration.” Ecological Engineering 15: 199-209. https://doi.org/10.1016/S0925-8574(00)00076-8

Konisky, R. A., D. M. Burdick, M. Dionne, and H. A. Neckles. 2006. "A Regional Assessment of Salt Marsh Restoration and Monitoring in the Gulf of Maine." Restoration Ecology 14: 516-525.

https://doi.org/10.1111/j.1526-100X.2006.00163.x

Lewis, R. R. 2000. "Ecologically Based Goal Setting in Mangrove Forest and Tidal Marsh Restoration." Ecological Engineering 15: 191-198. https://doi.org/10.1016/S0925-8574(00)00070-7

Neckles, H. A., M. Dionne, D. M. Burdick, C. T. Roman, R. Buchsbaum, and E. Hutchins. 2002. "A Monitoring Protocol to Assess Tidal Restoration of Salt Marshes on Local and Regional Scales." Restoration Ecology 10: 556-563. https://doi.org/10.1046/i.1526-100X.2002.02033.x

Neckles, H. A., G. R. Guntenspergen, W. G. Shriver, N. P. Danz, W. A. Wiest, J. L. Nagel, and J. H. Olker. 2013. Identification of Metrics to Monitor Salt Marsh Integrity on National Wildlife Refuges in Relation to Conservation and Management Objectives. Final Report to USFWS, Northeast Region. Laurel, MD: USGS Patuxent Wildlife Research Center.

"Most salt marshes in the US have been degraded by human activities, and threats from physical alterations, surrounding landuse, species invasions, and global climate change persist. Salt marshes are unique and highly productive ecosystems with high intrinsic value to wildlife, and many National Wildlife Refuges (NWRs) have been established in coastal areas to protect large tracts of salt marsh and wetland-dependent species. Various management 
practices are employed routinely on coastal NWRs to restore and enhance marsh integrity and ensure ecosystem sustainability. Prioritizing NWR salt marshes for application of management actions and choosing among multiple management options requires scientifically-based methods for assessing marsh condition.

Monitoring is integral to structured decision-making (SDM), a formal process for decomposing a decision into its essential elements. Within a natural resource context, SDM involves identifying management objectives, alternative management actions, and expected management outcomes. The core of SDM is a set of criteria for measuring system performance and evaluating management responses. Therefore, use of SDM to frame natural resource decisions leads to logical selection of monitoring attributes that are linked explicitly to management needs."

https://www.pwrc.usgs.gov/prodabs/pubpdfs/7828_Neckles.pdf

Nicholls, R. J. 2003. "Case Study on Sea-Level Rise Impacts." OECD Workshop on the Benefits of Climate Policy: Improving Information for Policy Makers. Organization for Economic Cooperation and Development, ENV/EPOC/GSP(2003)9/FINAL.

"Global-mean sea-level rise occurred through the 2oth Century, and continued rise is one of the more certain impacts of global warming. This is resulting in a range of impacts including increased flood risk and submergence, salinisation of surface and ground waters, and morphological change, such as erosion and wetland loss. The potential human and ecosystem impacts in the 21st Century are significant but uncertain. Actual impacts will depend on a range of change factors in addition to the amount of sea-level rise and climate change, including a number of factors which are humancontrolled such as coastal land use and management approaches. Importantly, there is a strong 'commitment to sea-level rise' due to the long thermal lags of the ocean system and hence the response of sea-level rise to mitigation is slower than for other climate factors. Therefore, the main benefits of mitigation of climate change in terms of sea-level rise occur beyond the 21st Century. This means that the best response to sea-level rise and climate change in the coastal zone is an appropriate mixture of mitigation and adaptation. Hence, joint evaluation of mitigation and adaptation is required in the coastal zone as these policies are intertwined. Such assessments 
must continue beyond 2100 to provide the full implications of the different policy choices. Further, policymakers should note that the results of any assessment of sea-level rise and climate change depends on the scale of assessment and the detailed methods utilised. For instance, choices on adaptation are sensitive to spatial scale. Hence, there is a critical need to match policy questions and formulation to the appropriate level of assessment. Despite the concerns about sea-level rise, most countries appear to be ignoring changes in sea level in coastal planning at the present time. There is a need to develop adaptive capacity of vulnerable coastal areas such as small island states. The following research would assist in identifying such areas and improve climate policy formulation for coastal areas:

- More complete assessment of the range of possible impacts in the 21st Century and beyond, including the consequences of low probability/high impact events such as the collapse of the West Antarctic Ice Shelf;

- Improved regional and global integrated models to quantify and explore the impacts of sea-level rise and other changes, conducted in conjunction with more detailed local and national assessments which will provide more detailed information and allow for validation. This would assist identification of vulnerable coastal areas (or 'hotspots');

Continued assessment of the adaptation process in coastal zones as the actual impacts depend on the potential to adapt, which remains a major gap in our understanding."

https://www.oecd.org/env/cc/2483213.pdf

Palermo, M. R., and E. A. Dardeau, Jr. 1994. "Guidance for Wetland Restoration with Dredged Material.” Dredging '94. Vicksburg, MS: U.S. Army Engineer Waterways Experiment Station.

"Wetlands can be restored or created using dredged material that currently presents a disposal challenge. At several US Army Corps of Engineers sites around the country, dredged material has been used to create new wetlands and to restore degraded wetlands to a more productive state. Varying levels of restoration or creation -success $\bullet$ have been achieved for these projects due in part to a lack of definitive guidelines for site preparation, structure selection and 
siting, placement of dredged material, vegetation selection and installation and operation and maintenance. The US Army Engineer Waterways Experiment Station (WES) is in the process of developing a handbook for wetland restoration and establishment. The handbook encapsulates the experience gained under the Wetlands Research Program. The Dredged Material Research Program, and other research conducted at the WES. This paper summarizes the design sequence and design guidelines presented within the handbook and other general considerations that relate to the restoration and creation of wetlands using dredged material."

Redmond, A. M. 2000. "Dredge and Fill Regulatory Constraints in Meeting the Ecological Goals of Restoration Projects." Ecological Engineering 15: 181-189.

https://doi.org/10.1016/S0925-8574(00)00069-0

Scarton, F., J. W. Day, Jr, A. Rismondo, G. Cecconi, and D. Are. 2000. "Effects of an Intertidal Sediment Fence on Sediment Elevation and Vegetation Distribution in a Venice (Italy) Lagoon Salt Marsh.” Ecological Engineering 16: 223-233.

https://doi.org/10.1016/S0925-8574(00)00045-8

Simenstad, C., D. Reed, and M. Ford. 2006. "When is Restoration Not? Incorporating Landscape-Scale Processes to Restore SelfSustaining Ecosystems in Coastal Wetland Restoration." Ecological Engineering 26: 27-39.

https://doi.org/10.1016/j.ecoleng.2005.09.007

Steyer, G. D., C. E. Sasser, J. M. Visser, E. M. Swenson, J. A. Nyman, and R. C. Raynie. 2002. "A Proposed Coast-Wide Reference Monitoring System for Evaluating Wetland Restoration Trajectories in Louisiana." Journal of Environmental Monitoring and Assessment 81: 107-117.

https://doi.org/10.1023/A:1021368722681

Teal, J. M., and L. Weishar. 2005. "Ecological Engineering, Adaptive Management, and Restoration Management in Delaware Bay Salt Marsh Restoration." Ecological Engineering 25: 304-314. 
Thayer, G. W., and M. E. Kentula. 2005. "Coastal Restoration: Where Have We Been, Where Are We Now, and Where Should We Be Going?” Journal of Coastal Research 40: 1-5.

https://www.jstor.org/stable/25736611

Thom, R. M. 2000. "Adaptive Management of Coastal Ecosystem Restoration Projects.” Ecological Engineering 15: 365-372. https://doi.org/10.1016/S0925-8574(00)00086-0

Thom, R. M., and K. F. Wellman. 1996. Planning Aquatic Ecosystem Restoration Monitoring Programs. IWR Report 96-R-23. Pacific Northwest National Laboratory, Richland, Washington; final report prepared for U.S. Army Corps of Engineers, Institute for Water Resources, Alexandria, VA.

"The monitoring program is a valuable tool to determine restoration project success. U.S. Army Corps of Engineers (Corps) Circular No. 1105-2-210 (Corps 1995) provides guidance for ecosystem restoration activities. In that document, adaptive management is put forth as the technique to be employed in restoration projects because "success can vary due to a variety of technical and site specific factors." The document further specifies that a carefully designed monitoring program lies at the heart of adaptive management. The present report was written to facilitate the design of a restoration project monitoring program. The purpose of this report is to provide a systematic approach to planning, implementing, and interpreting monitoring programs for restoration projects.

Monitoring programs vary widely in level of effort and cost from small, simple programs to large and complex programs. The process defined below can be used to design a program at most levels, because the basic aspects (e.g., performance criteria, parameter selection, sampling intensity) of a monitoring program should be considered at any level."

https://www.iwr.usace.army.mil/Portals/70/docs/iwrreports/96r23.pdf 
U.S. Department of Interior (US DOI). 2015. Recommendations for Assessing the Effects of the DOI Hurricane Sandy Mitigation and Resilience Program on Ecological System and Infrastructure Resilience in the Northeast Coastal Region. The Department of the Interior Metrics Expert Group. Washington, DC: U.S. Department of the Interior.

This document includes recommendations intended to provide the DOI with a strategy for conducting an effective assessment of coastal resilience change enabled by the DOI-sponsored projects, and a road-map to best practices for improving coastal resilience into the future.

https://www.doi.gov/sites/doi.gov/files/migrated/news/upload/Hurricane-Sandy-projectmetrics-report.pdf

U.S. Department of Interior Fish and Wildlife Service (US FWS). 2014a. Environmental Assessment for the Narrow River Estuary Resilience Restoration Program. Rhode Island National Wildlife Refuge Complex, Charlestown, RI.

This is a regulatory document for a thin layer placement project in Rhode Island that was initiated in 2016.

US FWS. 2014b. Final Initial Study/Environmental Assessment for the Seal Beach National Wildlife Refuge Thin-Layer Salt Marsh Sediment Augmentation Pilot Project Orange County, California. San Diego National Wildlife Refuge Complex, Chula Vista, CA.

This is a regulatory document for a thin layer placement project in California that was initiated in 2016.

http://scc.ca.gov/webmaster/ftp/pdf/sccbb/2014/1410/20141002Board11_Seal_Beach_Se diment_Augmentation_Ex4.pdf

Water Resources Development Act of 2007 (WRDA 2007). Section 2039 Monitoring Ecosystem Restoration. Public Law 110-114.

"SEC. 2039. MONITORING ECOSYSTEM RESTORATION.

(a) In General- In conducting a feasibility study for a project (or a component of a project) for ecosystem restoration, the Secretary shall ensure that the recommended project includes, as an integral 
part of the project, a plan for monitoring the success of the ecosystem restoration.

(b) Monitoring Plan- The monitoring plan shall-

(1) include a description of the monitoring activities to be carried out, the criteria for ecosystem restoration success, and the estimated cost and duration of the monitoring; and (2) specify that the monitoring shall continue until such time as the Secretary determines that the criteria for ecosystem restoration success will be met.

(c) Cost Share- For a period of 10 years from completion of construction of a project (or a component of a project) for ecosystem restoration, the Secretary shall consider the cost of carrying out the monitoring as a project cost. If the monitoring plan under subsection (b) requires monitoring beyond the 10-year period, the cost of monitoring shall be a non-Federal responsibility."

Weinstein, M. P., J. M. Teal, J. H. Balletto, and K. A. Strait. 2001. "Restoration Principles Emerging from One of the World's Largest Tidal Marsh Restoration Projects." Wetlands Ecology and Management 9: 387-407. https://doi.org/10.1023/A\%3A1012058713910

Wigand, C., T. Ardito, C. Chaffee, W. Ferguson, S. Paton, K. Raposa, C. Vandemoer, and E. Watson. 2015. "A Climate Change Adaptation Strategy for Management of Coastal Marsh Systems.” Estuaries and Coasts 40(3): 682-693.

https://doi.org/10.1007/s12237-015-0003-y

Wilber, P. 1993. Environmental Effects of Dredging Technical Notes: Managing Dredged Material via Thin-Layer Disposal in Coastal Marshes. EEDP-01-32. Vicksburg, MS: U.S. Army Engineer Research and Development Center.

"This technical note describes how dredged material can be successfully managed in an environmentally sound manner in 
marshes by placing it in layers of 5 to $15 \mathrm{~cm}$. (Unless otherwise indicated, all layer thicknesses indicated in this report refer to material that has undergone post-disposal consolidation.) Environmental studies of this process and of the regulatory history of thin-layer disposal in marshes are summarized. General planning and monitoring considerations are described, including descriptions of the types of equipment used to place dredged material in thin layers in marshes.

This note complements Environmental Effects of Dredging Information Exchange Bulletins, Volumes D-92-1, D-92-3, and D92-5, which describe case histories of thin-layer disposal, and an upcoming Environmental Effects of Dredging technical note, which will provide additional detail on engineering aspects of managing dredged material by thin-layer disposal. Together, these documents provide guidance for the planning, execution, and monitoring of thin-layer disposal in marshes."

http://hdl.handle.net/11681/8802

Zedler, J. B. 1996. "Coastal Mitigation in Southern California: The Need for a Regional Restoration Strategy.” Ecological Applications 6: 84-93.

https://doi.org/10.2307/2269555

Zedler, J. B. 2000. "Progress in Wetland Restoration Ecology." Tree 15: $402-407$. https://doi.org/10.1016/S0169-5347(00)01959-5

Zhao, Q., J. Bai, L. Huang, B. Gu, Q. Lu, and Z. Gao. 2016. "A Review of Methodologies and Success Indicators for Coastal Wetland Restoration." Ecological Indicators 60: 442-452. https://doi.org/10.1016/j.ecolind.2015.07.003

\section{Adaptive Management}

Adam, P. 2009. "Salt Marsh Restoration." In Coastal Wetlands: An Integrated Ecosystem Approach, edited by G. Perillo, E. Wolanski, D. Cahoon, and M. Brinson, 737-761. New York: Elsevier. 
This book chapter summarizes salt marsh restoration strategies including specifying objectives, planning for future conditions, addressing the cause of marsh degradation, and managing disturbances.

Ayyub, B. M., and M. S. Kearney. 2012. Sea Level Rise and Coastal Infrastructure Prediction, Risks, and Solutions. Reston, VA: American Society of Civil Engineers. https://ascelibrary.org/doi/pdf/10.1061/9780784412008

Boere, G. C., and D. Taylor. 2004. "Global and Regional Governmental Policy and Treaties as Tools towards the Mitigation of the Effect of Climate Change on Waterbirds." Ibis 146: 111-119. https://doi.org/10.1111/i.1474-919X.2004.00335.x

Borde, A. B., L.K. O'Rourke, R. M. Thom, G. W. Williams, and H. L. Diefenderfer. 2004. National Review of Innovative and Successful Coastal Habitat Restoration. Prepared for National Oceanic and Atmospheric Administration Coastal Services Center. Battelle Memorial Institute, Contract 44188. Sequim, WA.

"Coastal habitat restoration is a burgeoning science, with numerous organizations participating in an increasing number of projects and programs across the country. Examples of innovative and successful components of these efforts are summarized in this review. The information on projects and programs was collected through expert interviews and through a nationwide review of scientific literature, restoration plans, and Internet sources. The examples provided cover many coastal habitat types from the four coasts of the United States. The review provides information on restoration research and the innovative and successful components of funding, partnerships, planning, restoration methods and techniques, monitoring, adaptive management, information dissemination, and community involvement. The lessons learned from the experiences of the many sources noted in this review are summarized at the end of the paper. Through this work we hope to contribute toward the success of future restoration efforts."

https://repository.library.noaa.gov/view/noaa/2555 
Buchsbaum, R. N., and C. Wigand. 2012. "Adaptive Management and Monitoring as Fundamental Tools to Effective Salt Marsh Restoration." In Tidal Marsh Restoration: A Synthesis of Science and Management, edited by C. T. Roman and D. M. Burdick. Washington, DC: Island Press.

https://doi.org/10.5822/978-1-61091-229-7_14

Callaway, J. C., V. T. Parker, M. C. Vasey, and L. M. Schile. 2007. "Emerging Issues for the Restoration of Tidal Marsh Ecosystems in the Context of Predicted Climate Change." Madroño 54: 234-248. https://doi.org/10.3120/0024-9637(2007)54[234:EIFTR0]2.0.C0;2

Convertino, M., G. A. Kiker, M. L. Chu-Agor, R. Muñoz-Carpena, C. J. Martinez, M. Aiello-Lammens, H. R. Akçakaya, R. A. Fischer, and I. Linkov. 2011. Chapter 23: "Integrated Modeling to Mitigate Climate Change Risk Due to Sea Level Rise, Imperiled Shorebirds on Florida Coastal Military Installations." NATO Science for Peace and Security Series C: Environmental Security.

"Climate change is expected to significantly alter low-lying coastal and intertidal areas, which provide significant seasonal habitats for a variety of shoreline- dependent organisms. Many coastal military installations in Florida have significant coastal habitats and shoreline-dependent bird data strongly illustrate their seasonal importance for birds. Potential land use changes and population increases, coupled with uncertain predictions for sea level rise, storm frequency, and intensity have created a significant planning challenge for natural resource managers. This paper provides a framework to integrate multiscale climate, land cover, land use, and ecosystem information into a systematic tool to explore climate variability and change effects on habitat and population dynamics for the state-threatened residential Snowy Plover, and the migratory Piping Plover and Red Knot, on selected coastal Florida military sites in Northwest Florida. A proof-of-concept study is described that includes climate data, species distribution and a coastal wetland land cover model coupled with global sensitivity/uncertainty analysis methods. The results of these integrated models are used to explore habitat dynamics and management options within an uncertain world." 
Coastal Wetlands Planning, Protection, and Restoration Act (CWPPRA). 2015. Partners in Restoration.

"Meandering bayous, moss-filled trees, teeming wildlife against a backdrop of seemingly endless wetlands-these images have long depicted the cultural and environmental richness of coastal Louisiana. Familiar are the music and food that come from this region; less so is the economy derived from this natural bounty on which the country has come to depend. From these coastal waters comes nearly one-third of the Nation's fisheries, and one-quarter of the Nation's oil and gas supply is either produced or comes ashore in Louisiana's wetlands. The many miles of navigation channels and ports in the region account for nearly 20 percent of the Nation's waterborne commerce.

Because of these economic opportunities, nearly half of the State's population lives in the coastal zone. The importance of the economic contribution from Louisiana's coast is magnified by the fact that the coast is washing away at an alarming rate. This contribution is directly linked to the stability of the coastal wetlands that provide fish habitat and contain the infrastructure that has long supported energy production and commerce. As the land disappears, the human fabric that makes up south Louisiana and is enjoyed by thousands of visitors each year also will be lost. The tragedy of losing Louisiana's coast in terms of human and economic value is beyond enumeration and has become a matter of national concern. This is not only Louisiana's wetland - it is also the Nation's wetland."

Day, J. W., D. F. Boesch, E. J. Clairain, G. P. Kemp, S. B. Laska, W. J. Mitsch, K. Orth, H. Mashriqui, D. J. Reed, L. Shabman, C. A. Simenstad, B. J. Streever, R. R. Twilley, C. C. Watson, J. T. Wells, and D. F. Whigham. 2007. "Restoration of the Mississippi Delta: Lessons from Hurricanes Katrina and Rita." Science 315: 1,6791,684 .

https://dx.doi.org/10.1126/science.1137030 
DiGennaro, B., D. Reed, C. Swanson, L. Hastings, Z. Hymanson, M. Healey, S. Siegel, S. Cantrell, and B. Herbold. 2012. "Using Conceptual Models in Ecosystem Restoration Decision Making: An Example from the Sacramento-San Joaquin River Delta, California." San Francisco Estuary and Watershed Science 10: 1-15.

https://doi.org/10.15447/sfews.2012v10iss3art1

Ewel, K. C., C. Cressa, R. T. Kneib, P. S. Lake, L. A. Levin, M. A. Palmer, P. Snelgrove, and D. H. Wall. 2001. "Managing Critical Transition Zones.” Ecosystems 4: 452-460. https://doi.org/10.1007/s10021-001-0106-0

Fischenich, C. 2008. The Application of Conceptual Models to Ecosystem Restoration. EBA Technical Notes Collection. ERDC/EBA TN-08-1. Vicksburg, MS: U.S. Army Engineer Research and Development Center. www.wes.army.mil/el/emrrp.

"In its report to the Chief of Engineers, the U.S. Army Corps of Engineers (USACE) Environmental Advisory Board (EAB) recommended that (USACE, EAB 2006):

The Corps should encourage the explicit use of conceptual models to guide eco-system restoration planning and implementation. Conceptual models should be required as a first step in the planning process, as they provide a key link between early planning (e.g., an effective statement of problem, need, opportunity, and constraint) and later evaluation and implementation.

Conceptual models are descriptions of the general functional relationships among essential com-ponents of an ecosystem. They tell the story of "how the system works" and, in the case of ecosystem restoration, how restoration actions aim to alter those processes or attributes for the betterment of the system. As such, conceptual models can provide the Ecosystem Restoration Team with:

- a synthesis of the current understanding of how a system works

- help in understanding and diagnosing the underlying problem 
- a basis for isolating cause and effect and simplifying complex systems

- a common framework or "mental picture" from which to develop alternatives

- a tool for making qualitative predictions of ecosystem response

- a way to flag potential thresholds, from which system responses may accelerate or follow potentially unexpected or divergent paths

- a means by which to outline further restoration, $\mathrm{R} \& \mathrm{D}$, and computational efforts

- a supplement to numerical models for assessing project benefits and impacts

- a means of identifying appropriate monitoring indicators and metrics, and

- a basis for implementing adaptive management strategies

Most professionals rely heavily upon conceptual models, but few explicitly formulate and express the models such that they provide broad utility for ecosystem restoration. Model building consists of determining system parts, choosing the relationships that link these parts, specifying the mechanisms by which the parts interact, identifying missing information, and exploring the model behavior (Heemskerk et al. 2003). The model building process can be as enlightening as the model itself, because it reveals what is known and what is unknown about the connections and causalities in the systems under study."

http://hdl.handle.net/11681/4060

Glick, P., J. Clough, A. Polaczyk, B. Couvillion, and B. Nunley. 2013. "Potential Effects of Sea-Level Rise on Coastal Wetlands in Southeastern Louisiana." Journal of Coastal Research 63: 211-233. https://doi.org/10.2112/SI63-0017.1

Hackney, C. T. 2000. "Restoration of Coastal Habitats: Expectation and Reality.” Ecological Engineering 15: 165-170. https://doi.org/10.1016/S0925-8574(00)00067-7

Healey, M. C., P. L. Angermeier, K. W. Cummins, T. Dunne, W. J. Kimmerer, G. M. Kondolf, P. B. Moyle, D. D. Murphy, D. T. Patten, D. J. Reed, R. B. Spies, and R. H. Twiss. 2007. Conceptual Models 
and Adaptive Management in Ecological Restoration: The CALFED Bay-Delta Environmental Restoration Program.

"The CALFED Environmental Restoration Program is an element of a comprehensive effort to address water supply, water quality, flood risk, and ecosystem integrity in California's central valley and San Francisco Bay estuary. The program is based on two key features-a whole ecosystem approach and an adaptive management strategy. To be successful, the program must have a foundation of scientifically defensible models of the system to be managed that incorporate both ecological and sociological opportunities and constraints. This paper describes conceptual models at multiple spatial and temporal scales that support the restoration efforts, and describes the adaptive management that will accompany on-theground actions."

http://calwater.ca.gov/content/Documents/library/ERP/Big_Model_Paper_5-3-04.pdf

Hinkle, R. L., and W. J. Mitsch. 2005. "Salt Marsh Vegetation Recovery at Salt Hay Farm Wetland Restoration Sites on Delaware Bay." Ecological Engineering 25: 240-251. https://doi.org/10.1016/j.ecoleng.2005.04.011

Kentula, M. E. 2000. "Perspectives on Setting Success Criteria for Wetland Restoration.” Ecological Engineering 15: 199-209. https://doi.org/10.1016/S0925-8574(00)00076-8

La Peyre, M. K., B. Gossman, and B. P. Piazza. 2009. "Short- and LongTerm Response of Deteriorating Brackish Marshes and Open-Water Ponds to Sediment Enhancement by Thin-Layer Dredge Disposal.” Estuaries and Coasts 32: 390-402.

https://doi.org/10.1007/s12237-008-9126-8

Lewis, R. R. 2000. "Ecologically Based Goal Setting in Mangrove Forest and Tidal Marsh Restoration." Ecological Engineering 15: 191-198. https://doi.org/10.1016/S0925-8574(00)00070-7 
Neckles, H. A., M. Dionne, D. M. Burdick, C. T. Roman, R. Buchsbaum, and E. Hutchins. 2002. "A Monitoring Protocol to Assess Tidal Restoration of Salt Marshes on Local and Regional Scales." Restoration Ecology 10: 556-563. https://doi.org/10.1046/i.1526-100X.2002.02033.x

Nicholls, R. J. 2003. "Case Study on Sea-Level Rise Impacts." OECD Workshop on the Benefits of Climate Policy: Improving Information for Policy Makers. Organization for Economic Cooperation and Development, ENV/EPOC/GSP(2003)9/FINAL.

"Global-mean sea-level rise occurred through the 2oth Century, and continued rise is one of the more certain impacts of global warming. This is resulting in a range of impacts including increased flood risk and submergence, salinisation of surface and ground waters, and morphological change, such as erosion and wetland loss. The potential human and ecosystem impacts in the 21st Century are significant but uncertain. Actual impacts will depend on a range of change factors in addition to the amount of sea-level rise and climate change, including a number of factors which are humancontrolled such as coastal land use and management approaches. Importantly, there is a strong 'commitment to sea-level rise' due to the long thermal lags of the ocean system and hence the response of sea-level rise to mitigation is slower than for other climate factors. Therefore, the main benefits of mitigation of climate change in terms of sea-level rise occur beyond the 21st Century. This means that the best response to sea-level rise and climate change in the coastal zone is an appropriate mixture of mitigation and adaptation. Hence, joint evaluation of mitigation and adaptation is required in the coastal zone as these policies are intertwined. Such assessments must continue beyond 2100 to provide the full implications of the different policy choices. Further, policymakers should note that the results of any assessment of sea-level rise and climate change depends on the scale of assessment and the detailed methods utilised. For instance, choices on adaptation are sensitive to spatial scale. Hence, there is a critical need to match policy questions and formulation to the appropriate level of assessment. Despite the concerns about sea-level rise, most countries appear to be ignoring changes in sea level in coastal planning at the present time. There is a need to develop adaptive capacity of vulnerable coastal areas such 
as small island states. The following research would assist in identifying such areas and improve climate policy formulation for coastal areas:

- More complete assessment of the range of possible impacts in the 21st Century and beyond, including the consequences of low probability/high impact events such as the collapse of the West Antarctic Ice Shelf;

- Improved regional and global integrated models to quantify and explore the impacts of sea-level rise and other changes, conducted in conjunction with more detailed local and national assessments which will provide more detailed information and allow for validation. This would assist identification of vulnerable coastal areas (or 'hotspots'); Continued assessment of the adaptation process in coastal zones as the actual impacts depend on the potential to adapt, which remains a major gap in our understanding."

https://www.oecd.org/env/cc/2483213.pdf

National Research Council (NRC). 1995. Science, Policy, and the Coast: Improving Decision-Making. Washington, DC: National Academic Press.

"Coastal ecosystems are under stress from a variety of human activities, and many have experienced widespread degradation. Laws have been enacted and regulations implemented in an attempt to stem coastal environmental damage and guide responsible development, but these control measures are not always founded on adequate scientific information. Knowledge about coastal ecosystems, including the human component, is needed to enable management of these systems in a manner that will preserve their value and restore degraded systems while allowing economic development and a high quality of life. A continuous exchange of information between scientists and managers who focus on coastal areas is necessary to develop and use scientific results effectively and to address emerging environmental problems in coastal areas. This need is becoming more evident as the complexity of the relationships among the environment, resources, and the economic and social well-being of human populations is recognized fully. All stakeholders-scientists, 
managers, industry, the public, environmental groups, and othersshould be involved in coastal policy formation and management."

https://www.nap.edu/read/4968/chapter/1

National Research Council (NRC). 2010. A Scientific Assessment of Alternatives for Reducing Water Management Effects on Threatened and Endangered Fishes in California's Bay Delta. Water Science and Technology Board \& Ocean Studies Board, National Academy of Sciences. Washington DC: National Academy Press.

"California's Bay-Delta estuary is a biologically diverse estuarine ecosystem that plays a central role in the distribution of California's water from the state's wetter northern regions to its southern, arid, and populous cities and agricultural areas. In addition to its ecological functioning and the ecosystem services it provides, there are numerous withdrawals of freshwater from the delta, the largest being pumping stations that divert water into the federal Central Valley Project (CVP) and the State Water Project (SWP), primarily for agriculture and metropolitan areas. Most former wetland and marsh areas of the delta have been drained for agriculture, and are protected by an aging collection of levees. Some of those areas also contain small urban settlements."

https://www.nap.edu/read/12881/chapter/1

New York City Department of Environmental Protection (NYC DEP). 2007. Jamaica Bay Watershed Protection Plan. Volume 2.

"The value of Jamaica Bay is evident to all who have watched a glowing sunset while on its waters, or a flight of waterfowl coasting in for a landing. The residents who grew up fishing along its shorelines, boating around the tidal marshes, or exploring the natural areas of the estuary will attest to the value of the Bay as an important part of their lives and their identities. At the same time, the Jamaica Bay landscape is a living-space, work-space, and travel corridor. These two values reflect an important aesthetics and function, but represent only a fraction of the myriad values and roles associated with Jamaica Bay.

For thousands of years, Jamaica Bay has served as an important ecological resource for flora and fauna. The Bay has evolved over 
the last 25,000 years as an important and complex network of open water, salt marshes, grasslands, coastal woodlands, maritime shrublands, brackish and freshwater wetlands. The wildlife use of these systems is commensurate with this complex network of natural systems. These natural communities support 91 species of fish, 325 bird species (of which 62 are confirmed to breed locally) and are an important habitat for many species of reptiles, amphibians and mammals. The Bay is a critical stopover area along the Atlantic Flyway migration route and is one of the best birdwatching locations in the western hemisphere. The 20,000 acres of water, islands, marshes, and shorelines support seasonal or year round populations of 214 species of special concern, including state and federally endangered and threatened species. Because if tis geographic size and very diverse functioning natural habitats, it is no surprise that Jamaica Bay is a nationally and internationally renowned birding location. Jamaica Bay retains irreplaceable value for its self-sustaining ecological functions, as well as the proximity of its assets by foot, rail and car to the urban metropolis. A walk along the beaches of Breezy Point or a kayaking adventure among the Bay's wetland islands can be a true wilderness escape, with Manhattan as a backdrop."

https://www.esf.edu/glrc/documents/Jamaica\%20Bay\%20Watershed\%20Protection\%20Plan\% 20Executive\%20Summary.pdf

Redmond, A. M. 2000. "Dredge and Fill Regulatory Constraints in Meeting the Ecological Goals of Restoration Projects.” Ecological Engineering 15: 181-189.

https://doi.org/10.1016/S0925-8574(00)00069-0

Simenstad, C., D. Reed, and M. Ford. 2006. "When is Restoration Not? Incorporating Landscape-Scale Processes to Restore SelfSustaining Ecosystems in Coastal Wetland Restoration." Ecological Engineering 26: 27-39.

https://doi.org/10.1016/i.ecoleng.2005.09.007

Teal, J. M., and M. P. Weinstein. 2002. "Ecological Engineering, Design, and Construction Considerations for Marsh Restorations in Delaware Bay, USA. Ecological Engineering 18: 607-618. 
Teal, J. M., and L. Weishar. 2005. "Ecological Engineering, Adaptive Management, and Restoration Management in Delaware Bay Salt Marsh Restoration." Ecological Engineering 25: 304-314. https://doi.org/10.1016/j.ecoleng.2005.04.009

Thayer, G. W., and M. E. Kentula. 2005. "Coastal Restoration: Where Have We Been, Where Are We Now, and Where Should We Be Going?" Journal of Coastal Research 40: 1-5.

https://www.jstor.org/stable/25736611

Thom, R. M. 1997. "System-Development Matrix for Adaptive Management of Coastal Ecosystem Restoration Projects." Ecological Engineering 8: 219-232. https://doi.org/10.1016/S0925-8574(97)00012-8

Thom, R. M. 2000. "Adaptive Management of Coastal Ecosystem Restoration Projects.” Ecological Engineering 15: 365-372. https://doi.org/10.1016/S0925-8574(00)00086-0

Tol, R. S. J., R. J. T. Klein, and R. J. Nicholls. 2008. "Towards Successful Adaptation to Sea-Level Rise along Europe's Coasts." Journal of Coastal Research 24: 432-442.

https://doi.org/10.2112/07A-0016.1

U.S. Department of Interior Fish and Wildlife Service (US FWS). 2014a. Environmental Assessment for the Narrow River Estuary Resilience Restoration Program. Rhode Island National Wildlife Refuge Complex, Charlestown, RI.

This is a regulatory document for a thin layer placement project in Rhode Island that was initiated in 2016.

U.S. FWS. 2014c. Finding of No Significant Impact for the Seal Beach National Wildlife Refuge Thin-Layer Salt Marsh Sediment Augmentation Pilot Project Orange County, California. San Diego National Wildlife Refuge Complex, Chula Vista, CA.

This is a regulatory document for a thin layer placement project in California that was initiated in 2016. 
USACE. 2014. Procedures to Evaluate Sea-Level Change: Impacts, Responses, and Adaptation. Technical Letter ETL 1100-2-1. Washington, DC: U.S. Army Corps of Engineers.

This technical letter provides guidance for understanding the direct and indirect physical and ecological effects of projected future sea level change on USACE projects and systems of projects and considerations for adapting to those effects.

https://www.publications.usace.army.mil/Portals/76/Publications/EngineerTechnicalLetters/ET ㄴ﹎1100-2-1.pdf

Verhoeven, J. T. A., B. Beltman, R. Bobbink, and D. F. Whigham, eds. 2006. Wetlands and Natural Resource Management. Springer EBooks. Berlin: Springer. https://link.springer.com/content/pdf/10.1007\%2F978-3-540-33187-2.pdf

Warren, R. S., P. E. Fell, R. Rozsa, A. H. Brawley, A. C. Orsted, E. T. Olson, V. Swamy, and W. A. Niering. 2002. "Salt Marsh Restoration in Connecticut: 20 Years of Science and Management." Restoration Ecology 10: 497-513.

https://doi.org/10.1046/j.1526-100X.2002.01031.x

Water Resources Development Act of 2007 (WRDA 2007). Section 2039 Monitoring Ecosystem Restoration. Public Law 110-114.

“SEC. 2039. MONITORING ECOSYSTEM RESTORATION.

(a) In General- In conducting a feasibility study for a project (or a component of a project) for ecosystem restoration, the Secretary shall ensure that the recommended project includes, as an integral part of the project, a plan for monitoring the success of the ecosystem restoration.

(b) Monitoring Plan- The monitoring plan shall-

(1) include a description of the monitoring activities to be carried out, the criteria for ecosystem restoration success, and the estimated cost and duration of the monitoring; and 
(2) specify that the monitoring shall continue until such time as the Secretary determines that the criteria for ecosystem restoration success will be met.

(c) Cost Share- For a period of 10 years from completion of construction of a project (or a component of a project) for ecosystem restoration, the Secretary shall consider the cost of carrying out the monitoring as a project cost. If the monitoring plan under subsection (b) requires monitoring beyond the 10-year period, the cost of monitoring shall be a non-Federal responsibility."

Weinstein, M. P., J. M. Teal, J. H. Balletto, and K. A. Strait. 2001. "Restoration Principles Emerging from One of the World's Largest Tidal Marsh Restoration Projects." Wetlands Ecology and Management 9: 387-407. https://doi.org/10.1023/A\%3A1012058713910

Wigand, C., T. Ardito, C. Chaffee, W. Ferguson, S. Paton, K. Raposa, C. Vandemoer, and E. Watson. 2015. "A Climate Change Adaptation Strategy for Management of Coastal Marsh Systems." Estuaries and Coasts 40(3): 682-693.

https://doi.org/10.1007/s12237-015-0003-y

Willows, R. I., and R. K. Connell, eds. 2003. Climate Adaptation: Risk, Uncertainty and Decision-Making. United Kingdom Climate Impacts Programme (UKCIP) Technical Report. Oxford: UKCIP. https://ukcip.ouce.ox.ac.uk/wp-content/PDFs/UKCIP-Risk-framework.pdf

Zedler, J. B., and S. Kercher. 2005. "Wetland Resources: Status, Trends, Ecosystem Services, and Restorability." Annual Review of Environment and Resources 30: 39-74. https://doi.org/10.1146/annurev.energy.30.050504.144248

Zhao, Q., J. Bai, L. Huang, B. Gu, Q. Lu, and Z. Gao. 2016. "A Review of Methodologies and Success Indicators for Coastal Wetland Restoration." Ecological Indicators 60: 442-452. 


\section{Additional References}

Allen, J. R. L. 2000. "Morphodynamics of Holocene Salt Marshes: A Review Sketch from the Atlantic and Southern North Sea Coasts of Europe." Quaternary Science Reviews 19: 1155-1231.

https://doi.org/10.1016/S0277-3791(99)00034-7

Anisfeld, S. C. 2012. "Biogeochemical Responses to Tidal Restoration." In Tidal Marsh Restoration: A Synthesis of Science and Management, edited by C. T. Roman and D. M. Burdick. Washington, DC: Island Press. https://link.springer.com/content/pdf/10.5822\%2F978-1-61091-229-7.pdf

Arkema, K. K., G. Guannel, G. Verutes, S. A. Wood, A. Guerry, M. Ruckelshaus, P. Kareiva, M. Lacayo, and J. M. Silver. 2013. "Coastal Habitats Shield People and Property from Sea-Level Rise and Storms." Nature Climate Change 3: 913-919. https://doi.org/10.1038/nclimate1944

Aronson, J., S. Dhillion, and LeFloc'h. 1996. "On the Need to Select an Ecosystem of Reference, However Imperfect: A reply to Pickett and Parker." Restoration Ecology 3(1): 1-3. https://doi.org/10.1111/j.1526-100X.1995.tb00069.x

Baustian, J. J., and I. A. Mendelssohn. 2015. "Hurricane-Induced Sedimentation Improves Marsh Resilience and Vegetation Vigor under High Rates of Relative Sea Level Rise.” Wetlands 18: 3,3773,382 .

https://doi.org/10.1007/s13157-015-0670-2

Baustian, J. J., I. A. Mendelssohn, and M. W. Hester. 2012. "Vegetation's Importance in Regulating Surface Elevation in a Coastal Salt Marsh Facing Elevated Rates of Sea Level Rise." Global Change Biology 18: $3,377-3,382$.

https://doi.org/10.1111/j.1365-2486.2012.02792.x 
Belperio, A. P. 1993. "Land Subsidence and Sea Level Rise in the Port Adelaide Estuary: Implications for Monitoring the Greenhouse Effect." Australian Journal of Earth Sciences 40(4): 359-368. https://doi.org/10.1080/08120099308728087

Berkowitz, J., C. VanZomeren, and C. Piercy. 2017. "Marsh Restoration Using Thin Layer Sediment Addition: Intitial Soil Evaluation.” Wetland Science and Practice, March 2017. https://doi.org/10.1016/j.ecss.2018.07.021

Blum, L. K. 1993. "Spartina alterniflora Root Dynamics in a Virginia Marsh.” Marine Ecology Progress Series 102: 169-178. https://www.jstor.org/stable/24841991

Bowron, T. M., N. Neatt, D. van Proosdij, and J. Lundholm. 2012. "Salt Marsh Tidal Restoration in Canada's Maritime Provinces.” In Tidal Marsh Restoration: A Synthesis of Science and Management, edited by C. T. Roman and D. M. Burdick. Washington, DC: Island Press.

https://doi.org/10.5822/978-1-61091-229-7_13

Brawley, H. A., R. S. Warren, and R. A. Askins. 1998. "Bird Use of Restoration and Reference Marshes within the Barn Island Wildlife Management Area, Stonington, Connecticut, USA." Environmental Management 22: 625-633.

https://doi.org/10.1007/s002679900134

Bridges, T. S., P. W. Wagner, K. A. Burks-Copes, M. E. Bates, Z. A. Collier, C. J. Fischenich, J. Z. Gailani, L. D. Leuck, C. D. Piercy, J. D. Rosati, E. J. Russo, D. J. Shafer, B. C. Suedel, E. A. Vuxton, and T. V. Wamsley. 2015. Use of Natural and Nature-Based Features (NNBF) for Coastal Resilience. ERDC SR-15-1. Vicksburg, MS: U.S. Army Engineer Research and Development Center.

"Coastal systems are increasingly vulnerable to flooding due to the combined influence of coastal storms, development and population growth, geomorphic change, and sea level rise. This reality has given rise to efforts to make greater use of ecosystem-based approaches to reduce risks from coastal storms, approaches which 
draw from the capacity of wetlands, beaches and dunes, biogenic reefs, and other natural features to reduce the impacts of storm surge and waves. This report offers details regarding the use of natural and nature-based features (NNBF) to improve coastal resilience and was designed to support post-Hurricane Sandy recovery efforts under the North Atlantic Coast Comprehensive Study (NACCS). An integrative framework is offered herein that focuses on classifying NNBF, characterizing vulnerability, developing performance metrics, incorporating regional sediment management, monitoring and adaptively managing from a systems perspective, and addressing key policy challenges. As progress is made on these and other actions across the many organizations contributing to the use of NNBF, implementation of the full array of measures available will reduce the risks and enhance the resilience of the region's coastal systems."

http://hdl.handle.net/11681/4769

Brinker, D. F., J. M. McCann, B. Williams, and B. D. Watts. 2007. "Colonial-Nesting Seabirds in the Chesapeake Bay Region: Where Have We Been and Where Are We Going?” Waterbirds 30: 93104.

https://doi.org/10.1675/1524-4695(2007)030[0093:CSITCB|2.0.C0;2

Brinson, M. M., R. R. Christian, and L. K. Blum. 1995. "Multiple States in the Sea-Level Rise Induced Transition from Terrestrial Forest to Estuary." Estuaries 18: 648-659.

https://doi.org/10.2307/1352383

Bromirski, P. D., A. J. Miller, R. E. Flick, and G. Auad. 2011. "Dynamical Suppression of Sea Level Rise along the Pacific Coast of North America: Indications for Imminent Acceleration." Journal of Geophysical Research 116: Co7005.

https://doi.org/10.1029/2010JC006759

Broome, S. W., and C. B. Craft. 2009. "Tidal Marsh Creation.” In Coastal Wetlands: An Integrated Ecosystem Approach, edited by G. Perillo, E. Wolanski, D. Cahoon, and M. Brinson, 715-736. New York: Elsevier. 
Cahoon, D. R., J. W. Day, Jr., and D. J. Reed. 1999. “The Influence of Surface and Shallow Subsurface Soil Processes on Wetland Elevation: A Synthesis." Current Topics in Wetland Biogeochemistry 3: 72-88.

https://pubs.er.usgs.gov/publication/70094721

Cairns, J., Jr., 2000. "Setting Ecological Restoration Goals Technical Feasibility and Scientific Validity." Ecological Engineering 15: 1718.

https://doi.org/10.1016/S0925-8574(00)00068-9

Cazenave, A., and R. S. Nerem. 2004. "Present-Day Sea Level Change: Observations and Causes." Rev. Geophys. 42(3): RG3001. https://doi.org/10.1029/2003RG000139.

Christiansen, T., P. L. Wiberg, and T. G. Milligan. 1999. "Flow and Sediment Transport on a Tidal Salt Marsh Surface." Estuarine, Coastal, and Shelf Science 50: 305-331.

https://doi.org/10.1006/ecss.2000.0548

Church, J. A., P. U. Clark, A. Cazenave, J. M. Gregory, S. Jevrejeva, A. Levermann, M. A. Merrifield, G. A. Milne, R. S. Nerem, P. D. Nunn, A. J. Payne, W. T. Pfeffer, D. Stammer, and A. S. Unnikrishnan. 2013: "Sea Level Change." In Climate Change 2013: The Physical Science Basis. Contribution of Working Group I to the Fifth Assessment Report of the Intergovernmental Panel on Climate Change, edited by T. F. Stocker, D. Qin, G.-K. Plattner, M. Tignor, S. K. Allen, J. Boschung, A. Nauels, Y. Xia, V. Bex, and P. M. Midgley. United Kingdom and New York: Cambridge University Press.

https://doi.org/10.1017/CB09781107415324.026 
Coastal Conservancy. 2014. Seal Beach National Wildlife Refuge ThinLayer Salt Marsh Sediment Augmentation Pilot Project. Staff Recommendation, Project No. 14-029-01. California State Coastal Conservancy.

This is a document containing staff recommendations for a thin layer placement project in California that was initiated in 2016.

http://scc.ca.gov/webmaster/ftp/pdf/sccbb/2014/1410/20141002Board11_Seal_Beach_Se diment_Augmentation.pdf

Collins, J., and D. Ball. 2015. "Science Foundation Chapter 4: Connections to the Watersheds: The Estuarine-Terrestrial Transition Zone." Baylands Ecosystem Habitat Goals Science Update.

"Life in the Bay Area is concentrated along the bayshore. Most people live or work within half a mile of the Bay (US Census 2010). The history of people in the region living along the shoreline is evidenced by thousands of years of bayshore habitation and industry, with ancient shellmounds still apparent in shoreline parks to skyscrapers built over gold rush wharves in San Francisco. Maritime commerce connects the region to the rest of the world via seaports and airports built on the Bay edge. The remaining marshes of the Bay support most of the region's rare or endangered plants and animals (Harvey et al 1992). The edge of the Bay is packed with ecological, economic and cultural values."

https://baylandsgoals.org/wp-content/uploads/2015/10/BEHGU_SFC4.pdf

Coverdale, T. C., C. P. Brisson, E. W. Young, S. F. Yin, J. P. Donnelly, and M. D. Bertness. 2014. "Indirect Human Impacts Reverse Centuries of Carbon Sequestration and Salt Marsh Accretion." PLOS ONE 9: e93296.

https://doi.org/10.1371/journal.pone.0093296

Craft, C. 2007. "Freshwater Input Structures Soil Properties, Vertical Accretion, and Nutrient Accumulation of Georgia and U.S. Tidal Marshes." Limnology and Oceanography 52: 1,220-1,230.

https://doi.org/10.4319/lo.2007.52.3.1220 
Craft, C. B., E. D. Seneca, and S. W. Broome. 1993. "Vertical Accretion in Microtidal Regularly and Irregularly Flooded Estuarine Marshes." Estuarine Coastal and Shelf Science 37: 371-386.

https://doi.org/10.1006/ecss.1993.1062

Davy, A. J., M. J. H. Brown, H. L. Mossman, and A. Grant. 2011. "Colonization of a Newly Developing Salt Marsh: Disentangling Independent Effects of Elevation and Redox Potential on Halophytes." Journal of Ecology 99: 1,350-1,357.

https://doi.org/10.1111/j.1365-2745.2011.01870.x

El-Raey, M., K. R. Dewidar, and M. El-Hattab. 1999. "Adaptation to the Impacts of sea Level Rise in Egypt." Mitigation and Adaptation Strategies for Global Change 4: 343-361.

https://doi.org/10.1023/A:1009684210570

Engelhart, S. E., B. P. Horton, B. C. Douglas, W. R. Peltier, and T. E. Tornqvist. 2009. "Spatial Variability of Late Holocene and Early $20^{\text {th }}$ Century Sea-Level Rise along the Atlantic Coast of the United States." Geology 37: 1,115-1,118.

https://doi.org/10.1130/G30360A.1

Ericson, J. P., C. J. Vorosmarty, S. L. Dingman, L. G. Ward, and M. Meybeck. 2006. "Effective Sea-Level Rise and Deltas: Causes of Change and Human Dimension Implications." Global and Planetary Change 50: 63-82.

https://doi.org/10.1016/j.gloplacha.2005.07.004

Ezer, T., and L. P. Atkinson. 2014. "Accelerated Flooding along the U.S. East Coast: On the Impact of Sea-Level Rise, Tides, Storms, the Gulf Stream, and the North Atlantic Oscillations." Earth's Future 2: $1-21$.

https://doi.org/10.1002/2014EF000252 
Ezer, T., L. P. Atkinson, W. B. Corlett, and J. L. Blanco. 2013. "Gulf Stream's Induced Sea Level Rise and Variability along the U.S. MidAtlantic Coast.” Journal of Geophysical Research: Oceans 118: 113. https://doi.org/10.1002/igrc.20091

Fagherazzi, S., and A. M. Priestas. 2010. "Sediments and Water Fluxes in a Muddy Coastline: Interplay between Waves and Tidal Channel Hydrodynamics." Earth Surface Processes and Landforms 35: 284-293.

https://doi.org/10.1002/esp.1909

Fagherazzi, S., P. L. Wiberg, S. Temmerman, E. Struyf, Y. Zhao, and P. A. Raymond. 2013. "Fluxes of Water, Sediments, and Biogeochemical Compounds in Salt Marshes." Ecological Processes 2: 1-16. https://doi.org/10.1186/2192-1709-2-3

Feagin, R. A., S. M. Lozada-Bernard, T. M. Ravens, I. Moller, K. M. Yeager, and A. H. Baird. 2009. "Does Vegetation Prevent Wave Erosion of Salt Marsh Edges?” PNAS 106: 10,109-10,113.

https://doi.org/10.1073/pnas.0901297106

Ferland, F. A. 1990. Holocene Depositional History of the Southern New Jersey Barrier and Backbarrier Regions. TR-CERC-90-2. Vicksburg, MS: U.S. Army Corps of Engineers, Coastal Engineering Research Center.

"The subsurface stratigraphy of the backbarrier region of southern New Jersey was examined to determine the Holocene depositional history. The study area extends from Brigantine to Cape May and includes seven barrier islands and an extensive backbarrier region. Vibracores, augercores, surface samples, historical maps and charts, and radiocarbon dates were used to document the patterns of sedimentation.

The Holocene backbarrier stratigraphy is characterized by a fining upward sequence that consists of a basal marsh or lagoon, overlain by a sand facies, tidal flats, marshes, tidal channels, and shallow lagoons. These data reflect a change from higher to lower energy 
backbarrier conditions that resulted as the barrier islands migrated landward throughout the Holocene transgression."

French, J. R., and D. R. Stoddard 1992. "Hydrodynamics of Salt Marsh Creek Systems: Implications for Marsh Morphological Development and Material Exchange." Earth Surface Processes and Landforms 17: 235-252.

https://doi.org/10.1002/esp.3290170304

Garster, J. G., M. W. Huber, and K. D. White. 2015. Screening-Level Assessment of Projects with Respect to Sea Level Change. Civil Works Technical Report, CWTS 2015-16. Washington, DC: U.S. Army Corps of Engineers.

"This report contains a summary of the US Army Corps of Engineers (USACE) initial screening-level assessment of the vulnerability of projects with respect sea level change. This is the first phase of a series of progressively more detailed screening assessments that will be completed before embarking on detailed assessments of the most vulnerable projects and those with the highest consequences. The screening level assessments were completed by USACE district staff using a web-based tool that interfaces with USACE geospatial databases. The comprehensive evaluation with respect to sea level (CESL) web tool also relies on information developed by other agencies, including the Federal Emergency Management Agency (FEMA), National Oceanic and Atmospheric Administration (NOAA) and the US Geological Survey (USGS). This report contains a detailed description of the development of CESL, the process used to collect the initial vulnerability assessment (IVA) data, and the results of the screening. Of the 5545 projects initially considered by CESL due to proximity to the coastline (within 40 miles of a tidally influenced body of water), 1431 were prescreened as potentially impacted by sea level change and were evaluated in the initial screening assessment. About one-third of these projects (487) were identified as being vulnerable to changing sea levels, and thus require examination in more detail in the next phase of the screening. The vulnerable projects were ranked and sorted resulting in 25 Very High, 69 High, 188 Medium, and 205 Low priority projects. The CESL tool used in USACE screening-level analyses can be made 
available to others who wish to perform similar coastal vulnerability assessments. This technical transfer has already begun with the transfer of the technology to Army staff for Installations, Environment, and Energy in 2015. By developing, testing, and making this toolkit available to others, USACE is well-aligned with the recommendations of the White House State, Local, and Tribal Leaders Task Force released in November 2014."

Golet, F. C., D. H. A. Myshrall, L. R. Oliver, P. W. C. Paton, and B. C. Tefft. 2012. "Role of Science and Partnerships in Salt Marsh Restoration at the Galilee Bird Sanctuary, Narragansett, Rhode Island." In Tidal Marsh Restoration: A Synthesis of Science and Management, edited by C. T. Roman and D. M. Burdick. Washington, DC: Island Press. https://doi.org/10.5822/978-1-61091-229-7_20

Gornitz, V., S. Couch, and E. K. Hartig. 2002. "Impacts of Sea-Level Rise in the New York City Metropolitan Area." Global and Planetary Changes 32: 61-88.

https://doi.org/10.1016/S0921-8181(01)00150-3

Graham, S. A., and I. A. Mendelssohn. 2013. "Functional Assessment of Different Sediment Slurry Applications in a Deteriorating Brackish Marsh.” Ecological Engineering 51: 264-274.

https://doi.org/10.1016/i.ecoleng.2012.12.031

Griggs, G., J. Árvai, D. Cayan, R. DeConto, J. Fox, H. A. Fricker, R. E. Kopp, C. Tebaldi, and E. A. Whiteman. 2017. Rising Seas in California: An Update on Sea-Level Rise Science. California Ocean Protection Council Science Advisory Team Working Group. California Ocean Science Trust, April 2017.

"Global sea-level rise is the most obvious manifestation of climate change in the ocean. It is an issue that will have far-reaching consequences for California, given its 1100-mile open coastline and many additional miles of estuarine shoreline, as well as high concentrations of people and development along the coast. Sealevel rise will continue to threaten coastal communities and infrastructure through more frequent flooding and inundation, as well as increased cliff, bluff, dune, and beach erosion. Human development and pressures from a rising sea threaten the already 
diminished coastal wetlands along the California coast. Hundreds of miles of roads and railways, harbors and airports, power plants and wastewater treatment facilities, in addition to thousands of businesses and homes, are at risk from future flooding, inundation, and coastal retreat [1]. But the total potential impact of such coastal risks is significantly larger still: not only are economic assets and households in flood zones increasingly exposed, but also people's safety, lives, daily movement patterns, and sense of community and security could be disrupted. California also has the nation's largest ocean economy, valued at over $\$ 44$ billion/ year [2], with the great majority of it connected to coastal recreation and tourism, as well as ports and shipping. Many of the facilities and much of the infrastructure that support this ocean economy, as well as the State's many miles of public beaches, lie within a few feet of present high tide."

http://whttp://www.opc.ca.gov/webmaster/ftp/pdf/docs/rising-seas-in-california-an-updateon-sea-level-rise-science.pdfww.opc.ca.gov/webmaster/ftp/pdf/docs/rising-seas-in-californiaan-update-on-sea-level-rise-science.pdf.

Hackney, C. T., and W. J. Cleary. 1987. "Saltmarsh Loss in Southeastern North Carolina: Importance of Sea-Level Rise and Inlet Dredging." Journal of Coastal Research 3: 93-97.

https://www.jstor.org/stable/4297253

Hall, J. A., S. Gill, J. Obeysekera, W. Sweet, K. Knuuti, and J. Marburger. 2016. Regional Sea Level Scenarios for Coastal Risk Management: Managing the Uncertainty of Future Sea Level Change and Extreme Water Levels for Department of Defense Coastal Sites Worldwide. U.S. Department of Defense, Strategic Environmental Research and Development Program.

"Global change, including climate change, poses unique challenges to the Department of Defense (DoD). In particular, coastal military sites, and their associated natural and built infrastructure, operations, and readiness capabilities, are vulnerable to the impacts of rising global sea level and local extreme water level (EWL) events. One way to assess vulnerabilities and impacts is to pose plausible and scientifically credible future conditions, or scenarios, with regard to sea level and EWLs. A multi-agency group conducted a literature synthesis and applied research effort to develop such 
scenarios. This report and its accompanying scenario database provide regionalized sea level and EWL scenarios for three future time horizons (2035, 2065, and 2100) for 1,774 DoD sites worldwide. The global nature of DoD's presence required a broad and comprehensive approach that to this point has been lacking in similar efforts."

https://apps.dtic.mil/dtic/tr/fulltext/u2/1013613.pdf

Jarvis, J. C. 2010. Vertical Accretion Rates in Coastal Louisiana: A Review of the Scientific Literature. ERDC/EL TN-10-5. Vicksburg, MS: U.S. Army Engineer Research and Development Center.

"Coastal marshes in Louisiana continue to deteriorate despite largescale restoration efforts due, in part, to processes such as shallow and deep subsidence, sediment depletion, and sea level rise. The purpose of this technical note is to review and synthesize the available scientific literature concerning vertical accretion rates in Louisiana coastal marshes in response to a changing coastal environment."

http://hdl.handle.net/11681/3805

Karamouz, M., Z. Zahmatkesh, and S. Nazif. 2013. Realization of Sea Level Rise Using Climate Variables Considering Climate Change Scenarios. World Environmental and Water Resources Congress 2013, 1,402-1,409. doi:10.1061/9780784412947.138.

https://doi.org/10.1061/9780784412947.138

Kirwan, M. L., and J. P. Megonigal. 2013. "Tidal Wetland Stability in the Face of Human Impacts and Sea-Level Rise." Nature 504: 53-60. https://doi.org/10.1038/nature12856

Kirwan, M., and S. Temmerman. 2009. "Coastal Marsh Response to Historical and Future Sea-Level Rise.” Quaternary Science Reviews 28: $1,801-1,808$.

https://doi.org/10.1016/i.quascirev.2009.02.022 
Kirwan, M. L., G. R. Guntenspergen, A. D’Alpaos, J. T. Morris, S. M. Mudd, and S. Temmerman. 2010. "Limits on the Adaptability of Coastal Marshes to Rising Sea Level.” Geophysical Research Letters 37: L23401.

https://doi.org/10.1029/2010GL045489

Kolker, A. S., M. A. Allison, and S. Hameed. 2011. "An Evaluation of Subsidence Rates and Sea-Level Variability in the Northern Gulf of Mexico.” Geophys. Res. Lett. 38: L21404.

https://doi.org/10.1029/2011GL049458

Lawrence, D. S. L., J. R. L. Allen, and G. M. Havelock. 2004. "Salt Marsh Morphodynamics: An Investigation of Tidal Flows and Marsh Channel Equilibrium.” Journal of Coastal Research 20: 301-316. https://www.jstor.org/stable/4299284

Linthurst, R. A., and E. D. Seneca. 1979. "The Effects of Standing Water and Drainage Potential of the Spartina alterniflora-Substrate Complex in a North Carolina Salt Marsh.” Estuarine and Coastal Marine Science 11: 41-52.

https://doi.org/10.1016/S0302-3524(80)80028-4

Little, C. M., R. M. Horton, R. E. Kopp, M. Oppenheimer, and S. Yip. 2015. "Uncertainty in Twenty-First Century CMIP5 Sea Level Projections.” Journal of Climate 28: 838-852. https://doi.org/10.1175/JCLI-D-14-00453.1

McCall, B. D., and S. C. Pennings. 2012. "Geographic Variation in Salt Marsh Structure and Function.” Oecologia 170: 777-787. https://doi.org/10.1007/s00442-012-2352-6

Meehl, G. A., A. Hu, C. Tebaldi, J. M. Arblaster, W. M. Washington, H. Teng, B. M. Sanderson, T. Ault, W. G. Strand, and J. B. White III. 2012. "Relative Outcomes of Climate Change Mitigation Related to Global Temperatures versus Sea-Level Rise.” Nature Climate Change 2: 576-580. 
Mendelssohn, I. A., and K. L. McKee. 1988. "Spartina alterniflora DieBack in Lousiana: Time-Course Investigation of Soil.” Journal of Ecology 76: 509-521.

https://doi.org/10.2307/2260609

Mendelssohn, I. A., and E. D. Seneca. 1980. "The Influences of Soil Drainage on the Growth of Salt Marsh Cordgrass Spartina alterniflora in North Carolina." Estuarine and Coastal Marine Science 11: 27-40.

https://doi.org/10.1016/S0302-3524(80)80027-2

Meyssignac, B., and A. Cazenave. 2012. "Sea Level: A Review of PresentDay and Recent-Past Changes and Variability." Journal of Geodynamics 58: 96-109.

https://doi.org/10.1016/i.jog.2012.03.005

Milne, G. A., W. R. Gehrels, C. W. Hughes, and M. E. Tamisiea. 2009. "Identifying the Causes of Sea-Level Change." Nature Geoscience 2: 471-478.

https://doi.org/10.1038/nge0544

Mitsch, W. J., and J. G. Gosselink. 2000. Wetlands. 3rd edition. New Jersey: John Wiley \& Sons, Inc.

This comprehensive textbook offers information of wetland distribution, science, management, restoration, and regulation.

Moser, S. 2005. "Impact Assessments and Policy Responses to Sea-Level Rise in Three US States: An Exploration of Human-Dimension Uncertainties." Global Environmental Change 15: 353-369. https://doi.org/10.1016/i.gloenvcha.2005.08.002

Mote, P., A. Petersen, S. Reeder, H. Shipman, and L. W. Binder. 2008. Sea Level Rise in the Coastal Waters of Washington State. A report by University of Washington Climate Impact Group and Washington Department of Ecology.

"Local sea level rise (SLR) is produced by the combined effects of global sea level rise and local factors such as vertical land 
deformation (e.g., tectonic movement, isostatic rebound) and seasonal ocean elevation changes due to atmospheric circulation effects. In this document we review available projections of these factors for the coastal waters of Washington and provide low, medium, and high estimates of local SLR for 2050 and 2100.

The fourth Assessment Report of the Intergovernmental Panel on Climate Change (IPCC) projects global SLR over the course of this century to be between 18 and $38 \mathrm{~cm}(7-15$ ") for their lowest emissions scenario, and between 26 and $59 \mathrm{~cm}$, (10-23") for their highest emissions scenario. Based on the current science, our "medium" estimate of 21st century SLR in Washington is that in Puget Sound, local SLR will closely match global SLR. On the northwest Olympic Peninsula, very little relative SLR will be apparent due to rates of local tectonic uplift that currently exceed projected rates of global SLR. On the central and southern.

Washington coast, the number of continuous monitoring sites with sufficiently long data records is small, adding to the uncertainty of SLR estimates for this region. Available data points suggest, however, that uplift is occurring in this region, but at rates lower than that observed on the NW Olympic Peninsula.

The application of SLR estimates in decision making will depend on location, time frame, and risk tolerance. For decisions with long timelines and low risk tolerance, such as coastal development and public infrastructure, users should consider low-probability highimpact estimates that take into account, among other things, the potential for higher rates of SLR driven by recent observations of rapid ice loss in Greenland and Antarctica, which though observed were not factored into the IPCC's latest global SLR estimates. Combining the IPCC high emissions scenario with 1) higher estimates of ice loss from Greenland and Antarctica, 2) seasonal changes in atmospheric circulation in the Pacific, and 3) vertical land deformation, a low-probability high-impact estimate of local SLR for the Puget Sound Basin is $55 \mathrm{~cm}$ (22") by 2050 and $128 \mathrm{~cm}$ (50") by 2100. Low-probability, high impact estimates are smaller for the central and southern Washington coast ( $45 \mathrm{~cm}$ [18"] by 2050 and $108 \mathrm{~cm}$ [43"] by 2100), and even lower for the NW Olympic Peninsula (35 cm [14"] by 2050 and $88 \mathrm{~cm}$ [35"] by 2100) due to tectonic uplift (see Table III). The authors intend to continue 
investigating the factors contributing to local SLR and will provide updates to this report."

http://www.cses.washington.edu/db/pdf/moteetalslr579.pdf.

Mudd, S. 2011. "The Life and Death of Salt Marshes in Response to Anthropogenic Disturbance of Sediment Supply.” Geology 39: 511512.

https://doi.org/10.1130/focus052011.1

Mudd, S. M., S. M. Howell, and J. T. Morris. 2009. "Impact of Dynamic Feedbacks between Sedimentation, Sea-Level Rise, and Biomass Production on Near-Surface Marsh Stratigraphy and Carbon Accumulation." Estuarine, Coastal and Shelf Science 82: 377-389. https://doi.org/10.1016/j.ecss.2009.01.028

Nicholls, R. J., and A. Cazenave. 2010. "Sea-Level Rise and Its Impact on Coastal Zones.” Science 328: 517-1520.

https://doi.org/10.1126/science.1185782

Nicholls, R. J., and J. A. Lowe. 2006. "Climate Stabilization and Impacts of Sea-Level Rise.” In Avoiding Dangerous Climate Change, edited by H. J. Schellnhuber, 195-202. New York: Cambridge University Press.

This book chapter describes the impact of temperature and climate stabilization on sea level rise, and the implications of this stabilization. Adaptation and mitigation are considered for coastal areas to manage sea level rise.

Olff, H., J. De Leeuw, J. P. Bakker, R. J. Platerink, and H. J. van Wijnen. 1997. "Vegetation Succession and Herbivory in a Salt Marsh: Changes Induced by Sea Level Rise and Silt Deposition along an Elevation Gradient.” Journal of Ecology 85: 799-814. https://doi.org/10.2307/2960603

Palaima, A. 2012. Ecology, Conservation, and Restoration of Tidal Marshes: The San Francisco Estuary. Berkeley, CA: University of California Press. 
Orr, M., S. Crooks, and P. B. Williams. 2003. "Will Restored Tidal Marshes Be Sustainable?” San Francisco Estuary and Watershed Science 1: $1-33$.

https://doi.org/10.15447/sfews.2003v1iss1art5

Pennings, S. C., and M. D. Bertness. 2001. "Salt Marsh Communities.” In Marine Community Ecology, edited by M. D. Bertness, S. D. Gaines, and M. Hay, 289-316. Sunderland, MA: Sinauer Associates.

This book chapter summarizes general ecology, and environmental drivers and stressors that lead to particular salt marsh communities.

Rahmstorf, S. 2007. "A Semi-Empirical Approach to Projecting Future Sea-Level Rise.” Science 315: 368-370.

https://doi.org/10.1126/science.1135456

Redfield, A. C. 1972. "Development of a New England Salt Marsh." Ecological Monographs 42: 201-237.

https://doi.org/10.2307/1942263

Reed, D. J. 1989. "Patterns of Sediment Deposition in Subsiding Coastal Salt Marshes, Terrebonne Bay, Louisiana: The Role of Winter Storms." Estuaries 12: 222-227.

https://doi.org/10.2307/1351901

Reed, D. J. 1995. "The Response of Coastal Marshes to Sea-Level Rise: Survival or Submergence." Earth Surface Processes and Landforms 20: $39-48$.

https://doi.org/10.1002/esp.3290200105

Reed, D. J. 2002. "Sea-Level Rise and Coastal Marsh Sustainability: Geological and Ecological Factors in the Mississippi Delta Plain." Geomorphology 48: 233-243. https://doi.org/10.1016/S0169-555X(02)00183-6 
Rounds, R. A., R. M. Erwin, and J. H. Porter. 2004. "Nest-Site Selection and Hatching Success of Waterbirds in Coastal Virginia: Some Results of Habitat Manipulation." Journal of Field Ornithology 75: 317-329.

https://doi.org/10.1648/0273-8570-75.4.317

Sallenger, A. H., Jr., K. S. Doran, and P. A. Howd. 2012. "Hotspot of Accelerated Sea-Level Rise on the Atlantic Coast of North America." Nature Climate Change 2: 884-888.

https://doi.org/10.1038/nclimate1597

Shreffler, D. K., R. M. Thom, M. J. Scott, K. F. Wellman, M. A. Walters, and M. Curran. 1995. National Review of Non-Corps

Environmental Restoration Projects. IWR Report 95-R- 12. Pacific Northwest National Laboratory, Richland, Washington; final report prepared for U.S. Army Corps of Engineers, Institute for Water Resources, Alexandria, VA.

"Throughout the United States, there is an increased awareness and concern for the protection and restoration of environmental resources. Indeed, recognizing that humans have the potential to alter the Earth irreversibly, and that global population is increasing at an; estimated rate of 92 million per year, the need for protection and restoration of environmental resources is evident and urgent. The growing number of conferences, journals, and books pertaining to environmental restoration amply illustrates this theme (Shreffler and Thorn 1993). The National Research Council (NRC) report, Restoration of Aquatic Ecosystems (NRC 1992), stressed that failure to restore aquatic ecosystems promptly will result in sharply increased rates of extinction of species or ecosystem types, and in permanent ecological damage. NRC recommended that a national restoration program be developed for United States aquatic ecosystems to achieve a net gain in all aquatic resources. The ambitious goals of this program include restoration of 400,000 miles of river-riparian ecosystems, two million acres of lakes, and 10 million acres of wetlands by the year 2010 .

Within the U.S. Army Corps of Engineers (Corps), new Congressional authorities are providing more opportunities to pursue environmental restoration initiatives. This increased 
emphasis on environmental restoration, however, brings a concomitant need for improved techniques for evaluating and comparing environmental restoration projects and programs. Whether monetary or nonmonetary metrics are used, the Corps needs measures of the efficiency and effectiveness of alternative environmental projects and programs in order to better allocate limited resources.

To address these issues, the Corps has initiated the Evaluation of Environmental Investments Research Program (EEIRP). Overall management of this program has been assigned to the Corps Water Resources Support Center, Institute for Water Resources (IWR). The 3-year research program is intended to provide Corps planners with methods and techniques to aid in developing supportable environmental restoration and mitigation projects and plans. In addition, the EEIRP will develop a framework to provide decision makers with information to facilitate the allocation of limited funds among a range of proposed projects and programs. To accomplish these objectives, the research program has been divided into 10 specific study areas, called work units. The present report is provided as input to the Engineering Environmental Investments: Formulating Inputs and Monitoring Effectiveness (EEIFIME) Work Unit."

https://www.iwr.usace.army.mil/Portals/70/docs/iwrreports/95-R-12.pdf

Slocum, M. G., I. A. Mendelssohn, N. L. Kuhn. 2005. "Effects of Sediment Slurry Enrichment on Salt Marsh Rehabilitation: Plant and Soil Response over Seven Years.” Estuaries 28: 519-528. https://doi.org/10.1007/BF02696063

Stagg, C. L., and I. A. Mendelssohn. 2010. "Restoring Ecological Function to a Submerged Salt Marsh." Restoration Ecology 18: 10-17. https://doi.org/10.1111/i.1526-100X.2010.00718.x

Stevenson, J. C., L. G. Ward, and M. S. Kearney. 1986. "Vertical Accretion in Marshes with Varying Rates of Sea Level Rise." Estuarine Variability, 241-260. New York: Academic Press, Inc. https://doi.org/10.1016/B978-0-12-761890-6.50020-4 
Stumpf, R. P. 1983. "The Process of Sedimentation on the Surface of a Salt Marsh.” Estuarine, Coastal and Shelf Science 17: 495-508. https://doi.org/10.1016/0272-7714(83)90002-1

Sweet, W., J. Park, J. Marra, C. Zervas, and S. Gill. 2014. Sea Level Rise and Nuisance Flood Frequency Changes around the United States. NOS CO-OPS 073. Silver Spring, MD: Center for Operational Oceanographic Products and Services, National Ocean Service, National Oceanic and Atmospheric Administration.

"Throughout the United States, there is an increased awareness and concern for the protection and restoration of environmental resources. Indeed, recognizing that humans have the potential to alter the Earth irreversibly, and that global population is increasing at an; estimated rate of 92 million per year, the need for protection and restoration of environmental resources is evident and urgent. The growing number of conferences, journals, and books pertaining to environmental restoration amply illustrates this theme (Shreffler and Thorn 1993). The National Research Council (NRC) report, Restoration of Aquatic Ecosystems (NRC 1992), stressed that failure to restore aquatic ecosystems promptly will result in sharply increased rates of extinction of species or ecosystem types, and in permanent ecological damage. NRC recommended that a national restoration program be developed for United States aquatic ecosystems to achieve a net gain in all aquatic resources. The ambitious goals of this program include restoration of 400,000 miles of river-riparian ecosystems, two million acres of lakes, and 10 million acres of wetlands by the year 2010 .

Within the U.S. Army Corps of Engineers (Corps), new Congressional authorities are providing more opportunities to pursue environmental restoration initiatives. This increased emphasis on environmental restoration, however, brings a concomitant need for improved techniques for evaluating and comparing environmental restoration projects and programs. Whether monetary or nonmonetary metrics are used, the Corps needs measures of the efficiency and effectiveness of alternative environmental projects and programs in order to better allocate limited resources. 
To address these issues, the Corps has initiated the Evaluation of Environmental Investments Research Program (EEIRP). Overall management of this program has been assigned to the Corps Water Resources Support Center, Institute for Water Resources (IWR). The 3-year research program is intended to provide Corps planners with methods and techniques to aid in developing supportable environmental restoration and mitigation projects and plans. In addition, the EEIRP will develop a framework to provide decision makers with information to facilitate the allocation of limited funds among a range of proposed projects and programs. To accomplish these objectives, the research program has been divided into 10 specific study areas, called work units. The present report is provided as input to the Engineering Environmental Investments: Formulating Inputs and Monitoring Effectiveness (EEIFIME) Work Unit."

https://tidesandcurrents.noaa.gov/publications/NOAA_Technical_Report_NOS_COOPS_073.pd f

Temmerman, S., G. Govers, S. Wartel, and P. Mere. 2003. "Spatial and Temporal Factors Controlling Short-Term Sedimentation in a Salt and Freshwater Tidal Marsh, Scheldt Estuary, Belgium, SW Netherlands." Earth Surface Processes and Landforms 28: 739755 .

https://doi.org/10.1002/esp.495

Temmerman, S., P. Meire, T. J. Bouma, P. M. J. Herman, T. Ysebaert, and H. J. De Vriend. 2013. "Ecosystem-Based Coastal Defense in the Face of Global Change." Nature 504: 79-83.

https://doi.org/10.1038/nature12859

Titus, J. G. 1988. "Alternatives for Protecting Coastal Wetlands from the Rising Sea." Greenhouse Effect, Sea-Level Rise and Coastal Wetlands, 151-152. EPA 230-05-86-013. Washington, DC: U.S. Environmental Protection Agency.

"Previous studies suggest that the expected global warming from the greenhouse effect could raise sea level 50 to $200 \mathrm{~cm}$ ( 2 to $7 \mathrm{ft}$ ) in the next century. This article presents the first nationwide assessment of the primary impacts of such a rise on the United States: (1) the cost of protecting ocean resort communities by 
pumping sand onto beaches and gradually raising barrier islands in place; (2) the cost of protecting developed areas along sheltered waters through the use of levees (dikes) and bulkheads; and (3) the loss of coastal wetlands and undeveloped lowlands. The total cost for a 1-m rise would be between $\$ 270$ and $\$ 475$ billion, ignoring future development. We estimate that if no measures are taken to hold back the sea, a 1-m rise in sea level would inundate 30,000 sq $\mathrm{km}$ (14,000 sq mi), with wet and dry land each accounting for about half the loss. The $1500 \mathrm{sq} \mathrm{km}$ (600-700 sq $\mathrm{mi}$ ) of densely developed coastal lowlands could be protected for approximately $\$ 1000$ to $\$ 2000$ per year for a typical coastal lot. Given high coastal property values, holding back the sea would probably be cost-effective. The environmental consequences of doing so, however, may not be acceptable. Although the most common engineering solution for protecting the ocean coast, pumping sand, would allow us to keep our beaches, levees and bulkheads along sheltered waters would gradually eliminate most of the nation's wetland shorelines. To ensure the long-term survival of coastal wetlands, federal and state environmental agencies should begin to lay the groundwork for a gradual abandonment of coastal lowlands as sea level rises."

http://papers.risingsea.net/federal_reports/sea-level-rise-and-wetlands-chap5.pdf

Turner, R. E. 1997. "Wetland Loss in the Northern Gulf of Mexico: Multiple Working Hypotheses.” Estuaries 20: 1-13. https://doi.org/10.2307/1352716

Turner, R. E., J. J. Baustian, E. M. Swenson, and J. S. Spicer. 2006. "Wetland Sedimentation from Hurricanes Katrina and Rita." Science 314: 449-452.

https://doi.org/10.1126/science.1129116

U.S. Army Corps of Engineers (USACE). 2009. Water Resources Policies and Authorities Incorporating Sea-Level Change Considerations in Civil Works Programs. EC 1165-2-211. Washington, DC: U.S. Army Corps of Engineers.

"This circular provides United States Army Corps of Engineers (USACE) guidance for incorporating the direct and indirect physical effects of projected future sea-level change in managing, planning, engineering, designing, constructing, operating, and maintaining 
USACE projects and systems of projects. Recent climate research by the Intergovernmental Panel on Climate Change (IPCC) predicts continued or accelerated global warming for the 21st Century and possibly beyond, which will cause a continued or accelerated rise in global mean sea-level. Impacts to coastal and estuarine zones caused by sea-level change must be considered in all phases of Civil Works programs."

https://planning.erdc.dren.mil/toolbox/library/ECs/EC1165-2-211_1Jul2009.pdf

USACE. 2011. Sea-Level Change Considerations for Civil Works Programs. EC 1165-2-212. Washington, DC: U.S. Army Corps of Engineers.

"This circular provides United States Army Corps of Engineers (USACE) guidance for incorporating the direct and indirect physical effects of projected future sea-level change across the project life cycle in managing, planning, engineering, designing, constructing, operating, and maintaining USACE projects and systems of projects. Recent climate research by the Intergovernmental Panel on Climate Change (IPCC) predicts continued or accelerated global warming for the 21st Century and possibly beyond, which will cause a continued or accelerated rise in global mean sea-level. Impacts to coastal and estuarine zones caused by sea-level change must be considered in all phases of Civil Works programs."

https://planning.erdc.dren.mil/toolbox/library/ECs/EC11652212Nov2011.pdf

USACE. 2013. Incorporating Sea Level Change in Civil Works Programs. ER 1100-2-8162. Washington, DC: U.S. Army Corps of Engineers.

"This Regulation provides United States Army Corps of Engineers (USACE) guidance for incorporating the direct and indirect physical effects of projected future sea level change across the project life cycle in managing, planning, engineering, designing, constructing, operating, and maintaining USACE projects and systems of projects."

https://www.publications.usace.army.mil/Portals/76/Publications/EngineerRegulations/ER_11 00-2-8162.pdf 
USACE. 2015. Climate Change Adaptation Plan - Update to 2014 Plan. Prepared by the USACE Climate Preparedness and Resilience Steering Committee. Washington, DC: U.S. Army Corps of Engineers.

"This USACE 2015 Adaptation Plan is an update to the 2014 Adaptation Plan. The 2014 Adaptation Plan describes activities underway to evaluate the most significant climate change related risks to, and vulnerabilities in, agency operations and missions in both the short and long term, and outlines actions that USACE is taking to manage these risks and vulnerabilities. It contains an update on climate preparedness and resilience programs, policies, and plans USACE has already put in place, as well as information about progress on additional actions that will help us manage climate risks and build resilience in the short and long term." https://cdm16021.contentdm.oclc.org/utils/getfile/collection/p266001coll1/id/5265

Warren, R. S., and W. A. Niering. 1993. "Vegetation Change on a Northeast Tidal Marsh: Interaction of Sea-Level Rise and Marsh Accretion.” Ecology 74: 96-103.

https://doi.org/10.2307/1939504

Weston, N. B. 2014. "Declining Sediments and Rising Seas: An Unfortunate Convergence for Tidal Wetlands." Estuaries and Coasts 37: 1-23.

https://doi.org/10.1007/s12237-013-9654-8

Zervas, C. 2009. Sea Level Variations of the United States 1854-2006. NOS CO-OPS 053. Silver Spring, MD: Center for Operational Oceanographic Products and Services, National Ocean Service, National Oceanic and Atmospheric Administration.

https://tidesandcurrents.noaa.gov/publications/Tech_rpt_53.pdf 


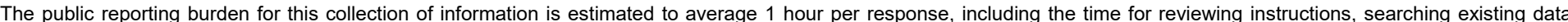

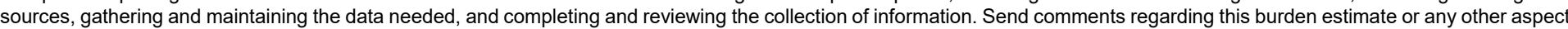

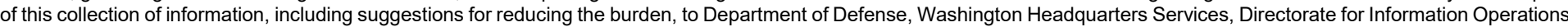

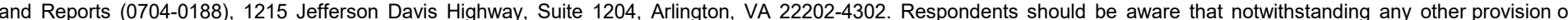
law, no person shall be subject to any penalty for failing to comply with a collection of information if it does not display a currently valid OMB control number. PLEASE DO NOT RETURN YOUR FORM TO THE ABOVE ADDRESS.

\begin{tabular}{l|l|l}
$\begin{array}{l}\text { 1. REPORT DATE } \\
\text { June } 2019\end{array}$ & $\begin{array}{l}\text { 2. REPORT TYPE } \\
\text { Final Report }\end{array}$ & 3. DATES COVERED (FrOm - To)
\end{tabular}

\section{TITLE AND SUBTITLE}

Maintaining Salt Marshes in the Face of Sea Level Rise - Review of Literature and Techniques

5a. CONTRACT NUMBER

5b. GRANT NUMBER

5c. PROGRAM ELEMENT NUMBER

6. AUTHOR(S)

Christine M. VanZomeren, Damarys Acevedo-Mackey, Elizabeth O. Murray, and Trudy J. Estes 5d. PROJECT NUMBER

5e. TASK NUMBER

5f. WORK UNIT NUMBER

15-ER-14

8. PERFORMING ORGANIZATION REPORT NUMBER

ERDC/EL SR-19-4

3909 Halls Ferry Road

Vicksburg, MS 39180-6199

9. SPONSORING/MONITORING AGENCY NAME(S) AND ADDRESS(ES)

Headquarters, U.S. Army Corps of Engineers

Washington, DC 20314-1000

\section{SPONSOR/MONITOR'S ACRONYM(S)} HQUSACE

\section{SPONSOR/MONITOR'S} REPORT NUMBER(S)

\section{DISTRIBUTION/AVAILABILITY STATEMENT}

Approved for public release; distribution is unlimited.

\section{SUPPLEMENTARY NOTES}

\section{ABSTRACT}

Guidance relevant to the maintenance and restoration of coastal salt marshes in the face of sea level rise is limited and sometimes conflicting; an understanding of ecological considerations and best management practices are needed to inform restoration and management that is appropriate, timely, successful, and sustainable. A literature search was conducted to assess the severity of current and projected impacts of sea level rise on salt marshes throughout the coastal regions of the United States, to identify other stressors contributing to relative sea level rise, to assess and consolidate current practices in marsh management, and to identify knowledge gaps that are impediments to development of consistent best management practices for restoring or maintaining marshes exhibiting degradation due to relative sea level rise.

Literature identified in this search is synthesized, organized by stressor type, relevant metrics, management actions, and adaptive management. The citations are presented in such a way as to be easily utilized by managers of marshes degraded by relative sea level rise. The results of this literature search will inform data acquisition efforts to address data gaps and uncertainties necessary to support development of a holistic approach to identifying, sustaining, and restoring impacted marsh areas.

\section{SUBJECT TERMS}

Climatic changes, Environmental management, Environmental protection, Salt marsh conservation, Salt marshes, Salt marsh restoration, Sea level

16. SECURITY CLASSIFICATION OF:

a. REPORT

Unclassified

\section{b. ABSTRACT}

Unclassified

\section{c. THIS PAGE}

Unclassified
17. LIMITATION OF ABSTRACT

SAR
18. NUMBER OF PAGES

178 19a. NAME OF RESPONSIBLE PERSON

Christine $M$ Van7omeren

19b. TELEPHONE NUMBER (Include area code)

601-634-3702 